\title{
Testing and Evaluation of Doubly Impacted Simulant-Fueled Milliwatt Generator Heat Sources
}

\author{
Paul E. Teaney, William B. Cartmill, \\ and Roscoe L. Wise
}

Issued: April 9, 1982

HIII $-110-82-64=0001$

DE82 012448

\section{MOUND FACILITY}

Mamisbung. Onio 45342

operated by

\section{MONSANTO RESEARCH CORPORATION \\ a subsidiary of Monsanto Company \\ for the \\ U. S. DEPARTMENT OF ENERGY}

Contract NO. DE-ACO4-76-DPODO53 


\section{DISCLAIMER}

This report was prepared as an account of work sponsored by an agency of the United States Government. Neither the United States Government nor any agency Thereof, nor any of their employees, makes any warranty, express or implied, or assumes any legal liability or responsibility for the accuracy, completeness, or usefulness of any information, apparatus, product, or process disclosed, or represents that its use would not infringe privately owned rights. Reference herein to any specific commercial product, process, or service by trade name, trademark, manufacturer, or otherwise does not necessarily constitute or imply its endorsement, recommendation, or favoring by the United States Government or any agency thereof. The views and opinions of authors expressed herein do not necessarily state or reflect those of the United States Government or any agency thereof. 


\section{DISCLAIMER}

Portions of this document may be illegible in electronic image products. Images are produced from the best available original document. 


\section{Abstract}

As part of the Milliwatt Generator (MWG) Program, 12 simulantfueled heat sources were fabricated, double impact tested, and evaluated at Mound. Ten assemblies were tested at $\sim 80 \mathrm{~m} / \mathrm{sec}$, and two were tested at $\sim 105 \mathrm{~m} / \mathrm{sec}$. None of the strength members were breached; therefore, no fuel would have been released as a result of double impacts at the velocities and orientations tested at $450^{\circ} \mathrm{C}$. There was little difference in results for duplicate tests conducted at $\sim 80$ and $\sim 105 \mathrm{~m} / \mathrm{sec}$. Ten units contained liners that were embrittled prior to testing. This resulted in cracks in some of the liners that would not have occurred in normally fueled heat sources.

\section{Introduction}

The Milliwatt Generator (MWG) radioisotopic heat source is used in radioisotopic thermoelectric generators (RTG's) where heat from the decay of ${ }^{238} \mathrm{PuO}_{2}$ is converted to electrical energy by means of thermoelectric materials. Safety considerations necessitate the complete containment of the radioactive fuel in these units in any credible accident environment. Therefore, the encapsulation materials must have sufficient high temperature strength to survive fire, high velocity impact, and long term use at the operating temperature of the RTG without releasing the fuel to the surrounding environment.

The double impact specimens in this study were fabricated and tested at Mound and are part of a series of compatibility, pressure burst, and impact studies being conducted for Sandia National Laboratories, Albuquerque (SNLA) to ensure the safety of the milliwatt generator heat source.

The heat source consists of two T-111 alloy $(90$ wt $\% \mathrm{Ta}, 8 \mathrm{wt} \% \mathrm{~W}, 2 \mathrm{wt} \% \mathrm{Hf}$ ) layers within an outer clad of Hastelloy C. Each layer consists of a deep drawn body with a flat cap gas tungsten arc (GTA) welded at one end. The liner cap and body are $0.51 \mathrm{~mm}$ thick and contain sufficient fuel to provide 4.5 thermal watts $[W($ th $)]$. A thin $(0.25 \mathrm{~mm})$ shim is used to cover the fuel during welding to protect the weld from contamination during closure. The strength member or secondary capsule consists of a $1.02 \mathrm{~mm}$ thick cup and $2.54 \mathrm{~mm}$ thick cap. The outer (Hastelloy C) clad provides oxidation resistance and consists of a $0.51 \mathrm{~mm}$ thick body and a $1.35 \mathrm{~mm}$ cap. The configuration of the heat source is shown in Figure 1. During the fabrication process (prior to encapsulation in the clad) the assembly is "pretreated" ( $1 \mathrm{hr}$ at $\left.1350^{\circ} \mathrm{C}\right)$ in a vacuum furnace to force the ${ }^{238} \mathrm{PuO}_{2} / \mathrm{Y}$ reaction "in situ," thus lowering the partial pressure of oxygen. The assemblies used for this study duplicated the heat source except that a fuel simulant (45 wt $\%$ W, 55 wt $\%$ Mo powder) was used instead of the radioisotopic fuel to allow the units to be evaluated under nonradioactive conditions.

\section{Procedure}

Twelve simulant-fueled capsules were doubly impacted and evaluated. The assemblies were heated to $450^{\circ} \mathrm{C}$ prior to each impact and were impacted against a hardened steel surface using a Utah Research and Development impact gun. Ten units were doubly impacted at $\sim 80 \mathrm{~m} / \mathrm{sec}$, and two were doubly impacted at $\sim 105 \mathrm{~m} / \mathrm{sec}$ at various orientations. The orientation and velocity of each test are given in Table 1 along with diagrams showing the order and angle of impact.

The assemblies were photographed to show the damage after each impact. In addition, the capsules were cross-sectioned along the plane of maximum damage and each component was examined for cracks or failure. The strength members and liners were also examined metallographically.

\section{Results}

Cross-sectioning and microscopic examination of WMT-10 after impact (Figures 2 through 8 ) revealed no evidence of a rupture of any of the capsule members. Cracks, however, existed in the weld underbead of the clad in the heat affected zone (HAZ) at the impact faces. 
There was no evidence of rupture of the clad or strength member of WMT-11 (Figures 9 through 19); however, the liner was fully breached at the dome end and side impact interface (Figures 15, 16 , and 17). Also, in one corner of the strength member weld nearest the cap, a slight crack initiation was noted, but there was no breach (Figure 18).

The condition of WMT-12 is shown in Figures 20 through 30 . Prior to the second impact, the capsule was oriented so that the corner impact surface would directly overlap the side impact surface at a $45^{\circ}$ angle; however, results show (Figures 20 and 22) that the impact surfaces overlapped only $\sim 50 \%$, and the impact angle was less than $45^{\circ}$. The clad of the capsule was fully breached ( $\sim 8 \mathrm{~mm}$ along the weld) in the area where the side and corner impact surfaces overlapped (Figure 21). The strength member and liner were not breached.

The testing of WMT-13 duplicated the test of WMT-12, except that the second impact hit as intended. The corner impact directly overlapped the side impact at an angle of $45^{\circ}$. The clad, strength member, and liner were not breached (Figures 31 through 43); however, the impact caused the shim to cut through the thickness of the liner $\sim 50 \%$ at one location near the weld (Figure 41).

The double impact of WMT-14 was conducted at $\sim 100 \mathrm{~m} / \mathrm{sec}$ in contrast to the previous capsules which were impacted at $\sim 80 \mathrm{~m} / \mathrm{sec}$. The impact angles were similar to those for WMT-12 (corner impact surface overlapped side impact surface $\sim 50 \%$ with impact angle $45^{\circ}$, Figure 45). Results (Figures 44-58) were similar to those for WMT-12. The strength member and liner were not breached (Figures 47 through 57); however, the clad was breached ( $\sim 6 \mathrm{~mm}$ ) along the cap side of the weld (Figure 46).

Photographs of WMT-15 are shown in Figures 59 through 66 . WMT-15 was impacted at $\sim 105$ $\mathrm{m} / \mathrm{sec}$ on the side and dome. Visual examination showed a breach in the clad in the dome at the location where the impact faces overlapped (Figure 60). Also, there was a crack in the weld underbead in the heat affected zone (HAZ) at the impact face. The strength member was neither cracked or breached. Although the liner was not breached, the material was sheared nearly through at the liner dome at the location where the impact faces overlapped (Figure 65).

WMT-17 was impacted at $\sim 80 \mathrm{~m} / \mathrm{sec}$ on the cap and dome, respectively. The condition of the capsule after each impact is shown in Figures 67 through 76 . The clad was breached in the heat affected zone of the cap to body weld. The strength member and liner were not breached; however, the liner was sheared $\sim 2 / 3$ through at one location in the weld (Figures 72 and 73 ). Also, several cracks existed (0.001 to 0.004 in. deep) along the inside surface of the liner dome (Figure 74).

The condition of WMYT-05 is shown in Figures 77 through 86 after cap corner and dome corner impacts at $80 \mathrm{~m} / \mathrm{sec}$. The clad, strength member, and liner were not breached. Cracks were found, however, in the clad sidewall adjacent to the weld on the impact face and in the dome end at the impact face and sidewall. The liner and strength member were in relatively good condition.

WMT-09 was impacted on the side and dome corner at $\sim 80 \mathrm{~m} / \mathrm{sec}$ (Figures 87 through 94). The weld underbead of the clad was cracked in the heat affected zone on the impact face; however, the clad was not breached. The liner and strength member were in good condition with no cracks or breach.

WMT-16 was impacted on the side and cap corner at $\sim 80 \mathrm{~m} / \mathrm{sec}$ (Figures 95 through 102). The clad cracked in the weld underbead in the heat affected zone at the impact face, but did not breach. The strength member and liner were in relatively good condition, with no cracks or breach.

WMT-18 was impacted on the dome and cap at $\sim 80 \mathrm{~m} / \mathrm{sec}$, respectively, (Figures 103 through 111). None of the capsule members was breached; however, a crack existed in the clad weld underbead in the heat affected zone at one location and several cracks existed on the inside of the liner dome (Figure 109).

WMT-31 was impacted on the dome corner and cap corner at $\sim 80 \mathrm{~m} / \mathrm{sec}$ (Figures 112 through 122). None of the three capsule members was cracked or breached. The shim cut slightly into the liner sidewall at the location shown in Figures 118 and 119. 


\section{Summary}

The results of the double impact tests are summarized in Table 2. None of the strength members was breached. WMT-31 (dome corner-cap corner at $\sim 80 \mathrm{~m} / \mathrm{sec}$ ) appeared to be the least damaged unit. The most damaged unit is difficult to distinguish. There appeared to be very little difference between the units tested at $\sim 80 \mathrm{~m} / \mathrm{sec}$ and $\sim 105 \mathrm{~m} / \mathrm{sec}$ at identical impact orientations.

Metallographic evaluation revealed that the liner of only one capsule (WMT-11, side/dome at $\sim 80 \mathrm{~m} / \mathrm{sec}$ ) was breached. The failure (shown in Figure 16) occurred on the dome end at the intersection of the side/dome impact. The strength member of WMT-11 was also slightly sheared (Figure 18) in the weld underbead. A tear (10.7 mils deep) was initiated in the HAZ of the weld underbead of WMT-12 (Figure 27).

Cracks were initiated along the inside surface of the liners of several of the units. The microstructure in Figure 123, typical for capsules WMT-10 through 18 and WMT-31, was indicative of liner embrittlement by oxygen. Embrittlement of the liners was confirmed by microhardness results.

Microhardness values for the liners of each assembly are shown in Figures 124 through 135. Results are shown for the sidewall, dome, and cap. These data suggest that three distinct differences between the assemblies existed prior to impact testing which could have affected the impact results for the liners. Ten of the liners (WMT-10 through 18 and WMT-31) were embrittled along the inside edge. The embrittlement was much more severe than would occur in a normal fueled unit. On the other hand, WMT-09 (Figure 132) and WMYT-05 (Figure 131) showed very little, if any, evidence of embrittlement. Metallographic and microhardness results for WMYT-05 were most like a fueled MWG heat source.
The fabrication histories of the assemblies revealed the reason for the differences. The group consisted of simulant units that were fabricated at different times. WMT-09 did not contain yttrium and was not pretreated. WMYT-05 contained yttrium and was pretreated. WMT-10 through 18 and WMT-31 were pretreated but did not contain yttrium. Although the simulant fuel was vacuum outgassed $\left(538^{\circ} \mathrm{C}\right.$ for $\left.1 \mathrm{hr}\right)$ prior to loading, the liners of these units were apparently embrittled by volatile surface oxides of molybdenum from the simulant fuel during pretreatment in much the same manner as would occur from the pretreatment of fueled units without yttrium).

Because of the embrittlement along the inside edge of these liners, cracks in the liners were more numerous after impact testing than would be expected in a fueled heat source. However, the strength member and clad results should be unaffected.

\section{Conclusion}

To summarize, none of the strength members was breached; therefore, no fuel would have been released as a result of the double impacts at the velocities and capsule orientations tested. There was little difference in results for duplicate tests at $\sim 80$ and $\sim 105 \mathrm{~m} / \mathrm{sec}$. Ten of the units contained liners which were embrittled along the inside edge prior to impact testing, resulting in cracks in some of the liners which would not have occurred in normally fueled heat sources.

In the future, all tungsten/molybdenum simulant fuel assemblies fabricated by Mound Facility will contain yttrium and will be pretreated during the fabrication process. This will ensure consistency among tests and will best duplicate a fueled heat source. 
Table 1 - ORIENTATION AND VELOCITY OF IMPACT TESTS

\begin{tabular}{|c|c|c|c|c|}
\hline \multirow{2}{*}{$\begin{array}{l}\text { Test } \\
\text { No. }\end{array}$} & \multirow{2}{*}{$\begin{array}{c}\text { Capsule } \\
\text { No. } \\
\end{array}$} & \multicolumn{2}{|c|}{ Orientation/Velocity $(\mathrm{m} / \mathrm{sec})$} & \multirow{2}{*}{$\begin{array}{c}\text { Reference } \\
\text { Diagram }\end{array}$} \\
\hline & & 1st hit & 2nd hit & \\
\hline 1 & WMT-10 & Side@ 80.4 & Opposite side @82.2 & A \\
\hline 2 & WMT-11 & Side@ 80.4 & Dome@ @ 78.8 & B \\
\hline 3 & WMT-12 & Side@80.4 & Weld corner@79.0 & C \\
\hline 4 & WMT-13 & Side@81.4 & Weld corner@81.5 & C \\
\hline 5 & WMT-14 & Side@105.3 & Weld corner@105.3 & C \\
\hline 6 & WMT-15 & Side@105.7 & Dome@104.0 & B \\
\hline 7 & WMT-17 & Cap@80.5 & Dome@80.7 & $\mathrm{D}$ \\
\hline 8 & WMYT-05 & Weld corner@81.6 & Opposite dome corner@80.5 & $\mathrm{E}$ \\
\hline 9 & WMT-09 & Side@82.5 & Opposite dome corner@79.1 & $F$ \\
\hline 10 & WMT-16 & Side@81.7 & Opposite weld corner@79.1 & G \\
\hline 11 & WMT-18 & Dome@ 80.6 & Cap@78.4 & $\mathrm{H}$ \\
\hline 12 & WMT-31 & Dome corner@83.0 & Opposite weld corner@81.8 & 1 \\
\hline
\end{tabular}

\section{ORDER AND ANGLE OF IMPACT}
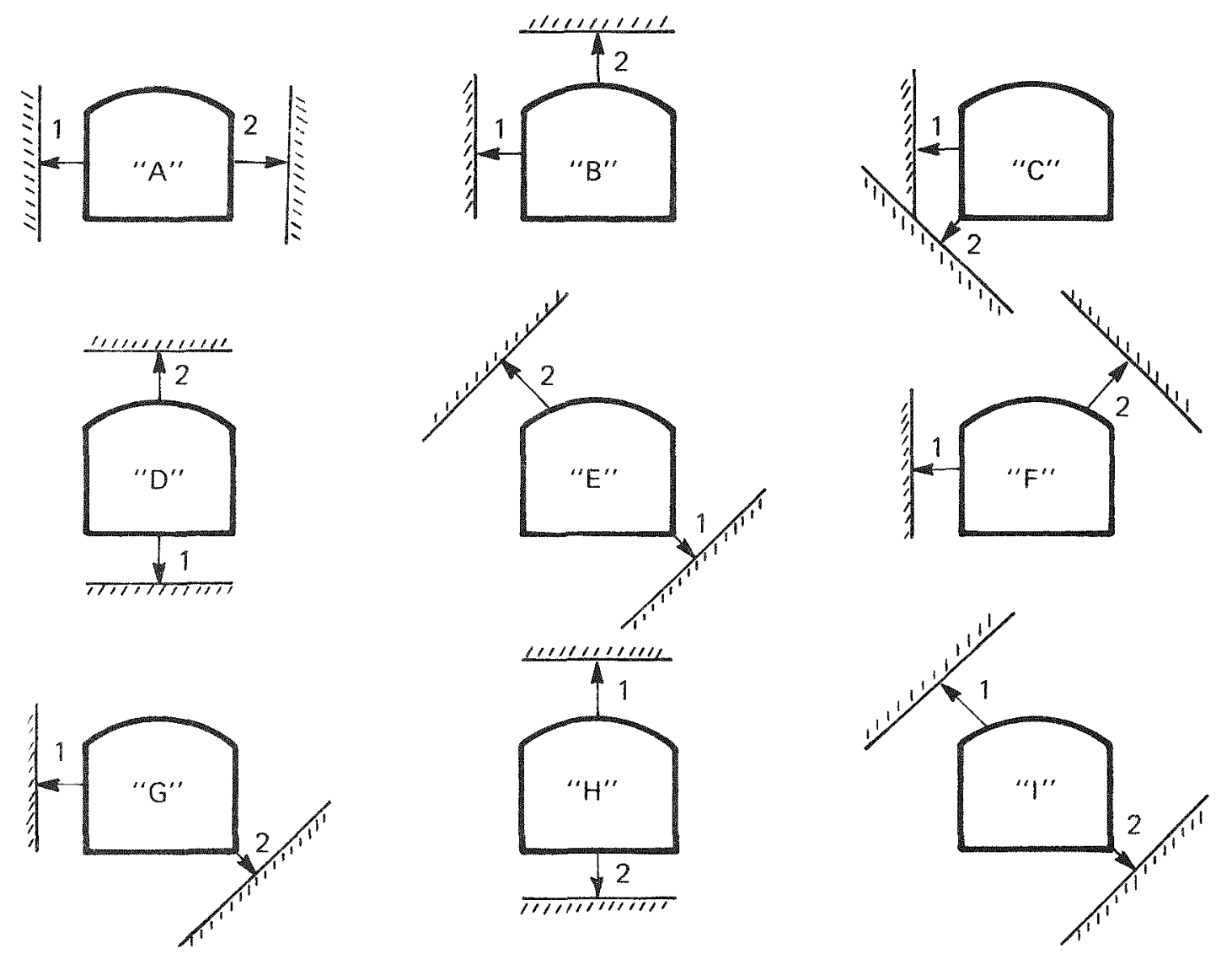
Table 2 - SUMMARY OF DOUBLE IMPACT TESTS

\begin{tabular}{|c|c|c|c|c|c|c|}
\hline \multirow{2}{*}{$\begin{array}{l}\text { Test } \\
\text { No. }\end{array}$} & \multicolumn{3}{|c|}{ Orientation/Velocity $(\mathrm{m} / \mathrm{sec})$} & \multicolumn{3}{|c|}{ Observations } \\
\hline & Capsule & 1st hit & 2nd hit & Clad & Strength Member & Liner \\
\hline 1 & WMT-10 & $\begin{array}{l}\text { Side } \\
\text { @ } 80.4\end{array}$ & $\begin{array}{l}\text { Opposite } \\
\text { side } \\
\text { (a) } 82.2\end{array}$ & $\begin{array}{l}\text { Cracked in under- } \\
\text { bead HAZ at impact } \\
\text { faces; not breached }\end{array}$ & OK & OK \\
\hline 2 & WMT-11 & $\begin{array}{l}\text { Side } \\
\text { @ } 80.4\end{array}$ & $\begin{array}{l}\text { Dome } \\
@ 78.8\end{array}$ & $\begin{array}{l}\text { Cracked in under- } \\
\text { bead HAZ at impact } \\
\text { face; not breached }\end{array}$ & $\begin{array}{l}\text { Shear initiated } \\
\text { in weld underbead } \\
\text { (18.6 mils) }\end{array}$ & $\begin{array}{l}\text { Breached on dome } \\
\text { end at impact face }\end{array}$ \\
\hline 3 & WMT-12 ${ }^{\mathrm{a}}$ & $\begin{array}{l}\text { Side } \\
\text { (a) } 80.4\end{array}$ & $\begin{array}{l}\text { Weld } \\
\text { corner } \\
\text { @ } 79.0\end{array}$ & $\begin{array}{l}\text { Breached in HAZ at } \\
\text { impact overlap }\end{array}$ & $\begin{array}{l}\text { Tear initiated in HAZ } \\
\text { of underbead } \\
\text { (10.7 mils) }\end{array}$ & OK \\
\hline 4 & WMT-13 & $\begin{array}{l}\text { Side } \\
\text { (a) } 81.4\end{array}$ & $\begin{array}{l}\text { Weld } \\
\text { corner } \\
\text { (d) } 81.5\end{array}$ & $\begin{array}{l}\text { Cracked in under- } \\
\text { bead } H A Z \text { and in } \\
\text { cap at impact face }\end{array}$ & OK & OK \\
\hline 5 & WMT-14 & $\begin{array}{l}\text { Side } \\
@ 105.3\end{array}$ & $\begin{array}{l}\text { Weld } \\
\text { corner } \\
\text { @ } 105.3\end{array}$ & $\begin{array}{l}\text { Breached in weld } \\
\text { at impact overlap }\end{array}$ & OK & $\begin{array}{l}\text { Cracked inside on } \\
\text { corner of dome and } \\
\text { sidewall at impact face }\end{array}$ \\
\hline 6 & WMT-15 & $\begin{array}{l}\text { Side } \\
\text { (a) } 105.7\end{array}$ & $\begin{array}{l}\text { Dome } \\
\text { (a) } 104.0\end{array}$ & $\begin{array}{l}\text { Cracked in under- } \\
\text { bead HAZ at impact } \\
\text { face; breached at dome } \\
\text { end at impact overlap }\end{array}$ & OK & OK \\
\hline 7 & WMT-17 & $\begin{array}{l}\text { Cap } \\
@ 80.5\end{array}$ & $\begin{array}{l}\text { Dome } \\
\text { @ } 80.7\end{array}$ & $\begin{array}{l}\text { Breached in HAZ of } \\
\text { cap to body weld }\end{array}$ & OK & $\begin{array}{l}\text { Several cracks in } \\
\text { liner dome inside sur- } \\
\text { face }(0.001 \text { in. and } \\
0.004 \text { in. deep); not } \\
\text { breached }\end{array}$ \\
\hline 8 & WMYT-05 & $\begin{array}{l}\text { Weld } \\
\text { corner } \\
@ 81.6\end{array}$ & $\begin{array}{l}\text { Opposite } \\
\text { dome } \\
\text { corner } \\
@ 80.5\end{array}$ & $\begin{array}{l}\text { Cracked in dome end } \\
\text { at impact face and } \\
\text { sidewall; cracked in } \\
\text { sidewall adjacent to } \\
\text { weld on impact face; } \\
\text { not breached }\end{array}$ & OK & OK \\
\hline 9 & WMT-09 & $\begin{array}{l}\text { Side } \\
\text { (Q) } 82.5\end{array}$ & $\begin{array}{l}\text { Opposite } \\
\text { dome } \\
\text { corner } \\
\text { (a) } 79.1\end{array}$ & $\begin{array}{l}\text { Cracked in under- } \\
\text { bead HAZ on impact } \\
\text { face; not breached }\end{array}$ & OK & OK \\
\hline 10 & WMT-16 & $\begin{array}{l}\text { Side } \\
@ 81.7\end{array}$ & $\begin{array}{l}\text { Opposite } \\
\text { weld } \\
\text { corner } \\
\text { @ } 79.1\end{array}$ & $\begin{array}{l}\text { Cracked in HAZ on } \\
\text { underbead; not } \\
\text { breached }\end{array}$ & OK & OK \\
\hline 11 & WMT-18 & $\begin{array}{l}\text { Dome } \\
\text { (a) } 80.6\end{array}$ & $\begin{array}{l}\text { Cap } \\
@ 78.4\end{array}$ & $\begin{array}{l}\text { Cracked in HAZ on } \\
\text { underbead; not } \\
\text { breached }\end{array}$ & OK & $\begin{array}{l}\text { Several cracks on } \\
\text { dome end on inside } \\
\text { surface; not breached }\end{array}$ \\
\hline 12 & WMT-31 & $\begin{array}{l}\text { Dome } \\
\text { corner } \\
\text { @ } 83.0\end{array}$ & $\begin{array}{l}\text { Opposite } \\
\text { weld } \\
\text { corner } \\
\text { (d) } 81.8\end{array}$ & OK & OK & OK \\
\hline
\end{tabular}

ampact surfaces did not directly overlap ( $\sim 50 \%$ overlap) and corner impact was biased toward cap. 
Clad body $(0.51 \mathrm{~mm}$ Hastellov $\mathrm{C}) \longrightarrow$

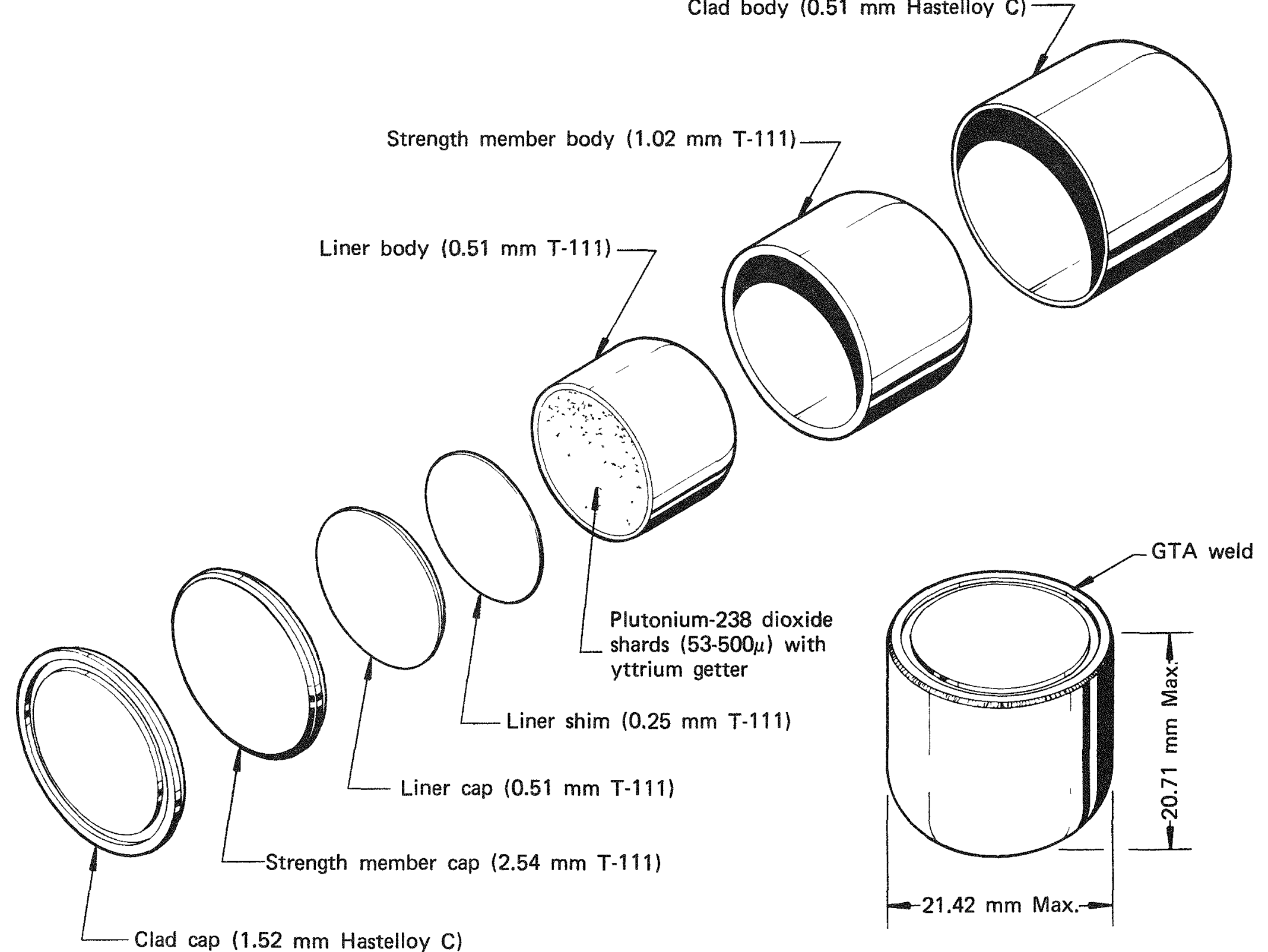




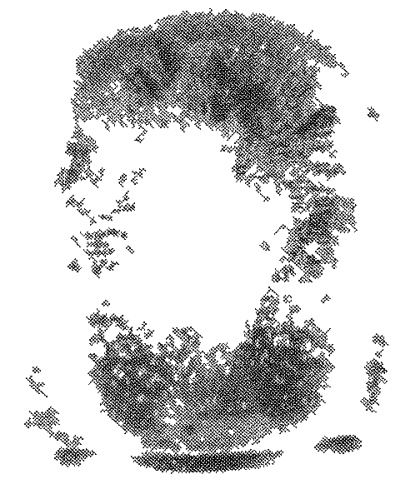

FIGURE 2 - WMT-10 (first impact face) after one side was impacted at $804 \mathrm{~m} / \mathrm{sec}$ Clad was not breached

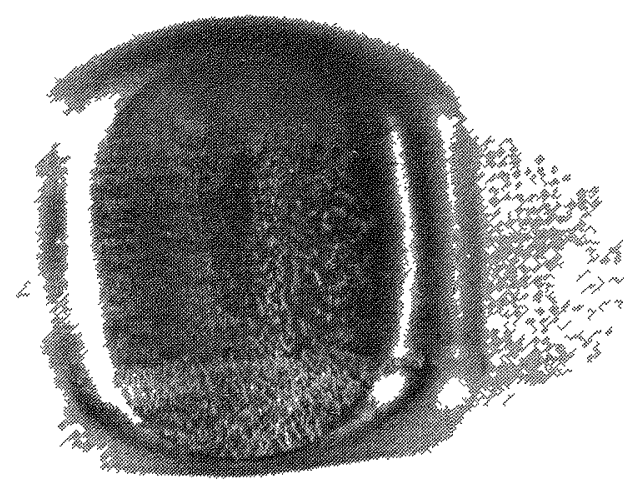

FIGURE 4 - WMT-10 strength member after double impact showing side of first impact. Strength member was not breached

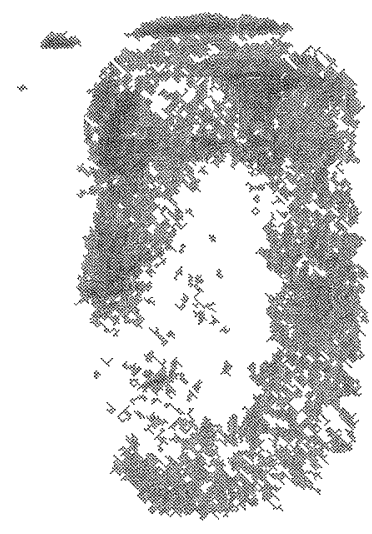

FIGURE 3 - WMT 10 (second impact face) after one side was impacted at $804 \mathrm{~m} / \mathrm{sec}$ and another side at $822 \mathrm{~m} / \mathrm{sec}$ Clad was not breached

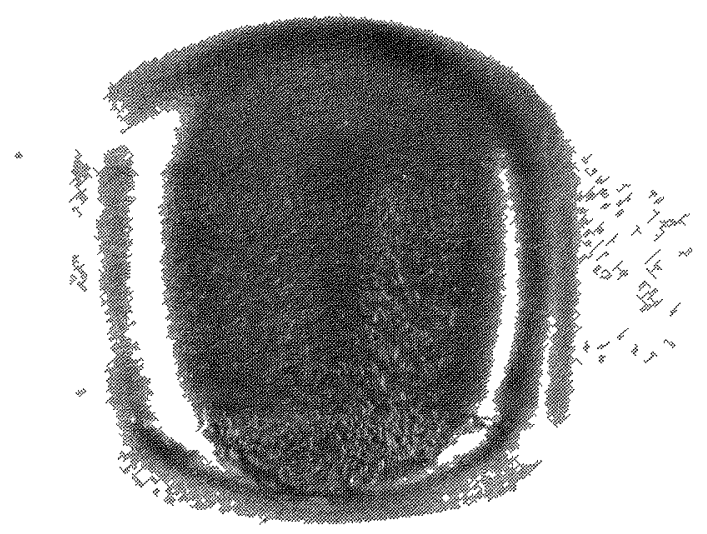

FIGURE 5 - WMT-10 strength member after double impact showing second impact side Strength member was not breached 


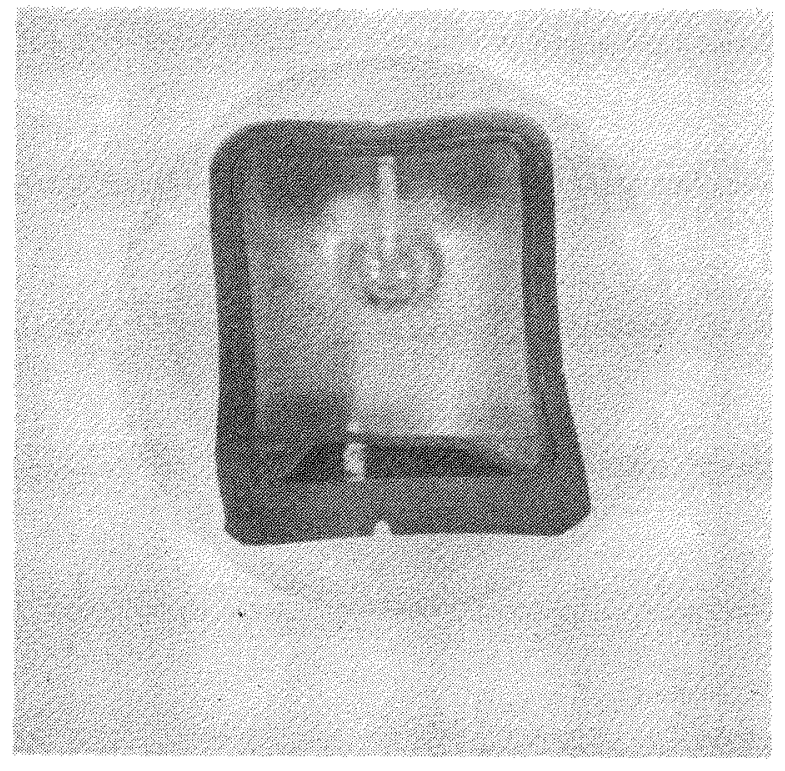

FIGURE 6 - WMT-10 cross-sectioned strength member and liner after double impact.

Strength member and liner were not breached. 


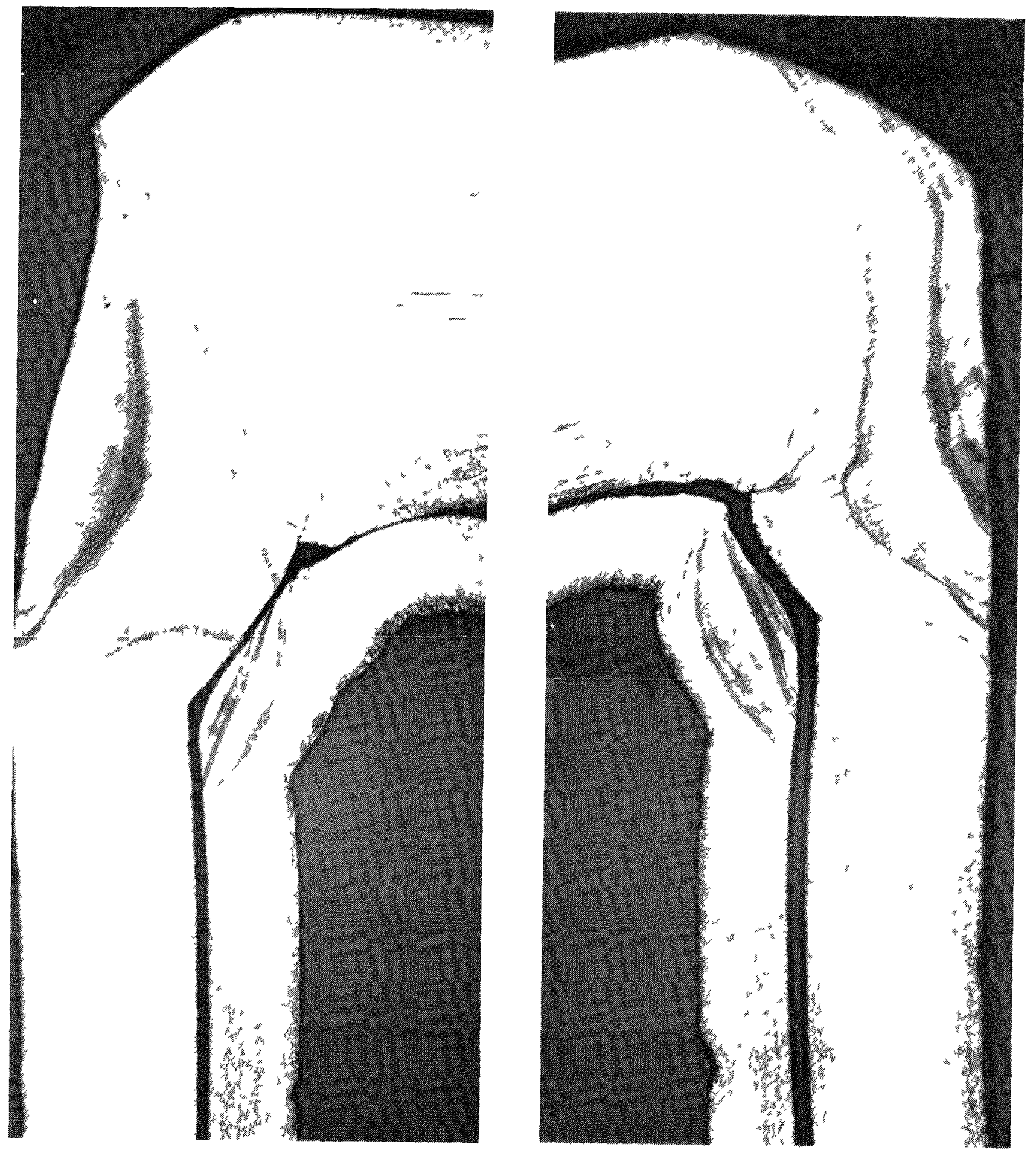

FIGURE 7 - WMT-10 cross section of liner and strength member welds through impact faces Note indentation in liner side wall caused by shim and fold in underbead of strength member weld (27 5X) 

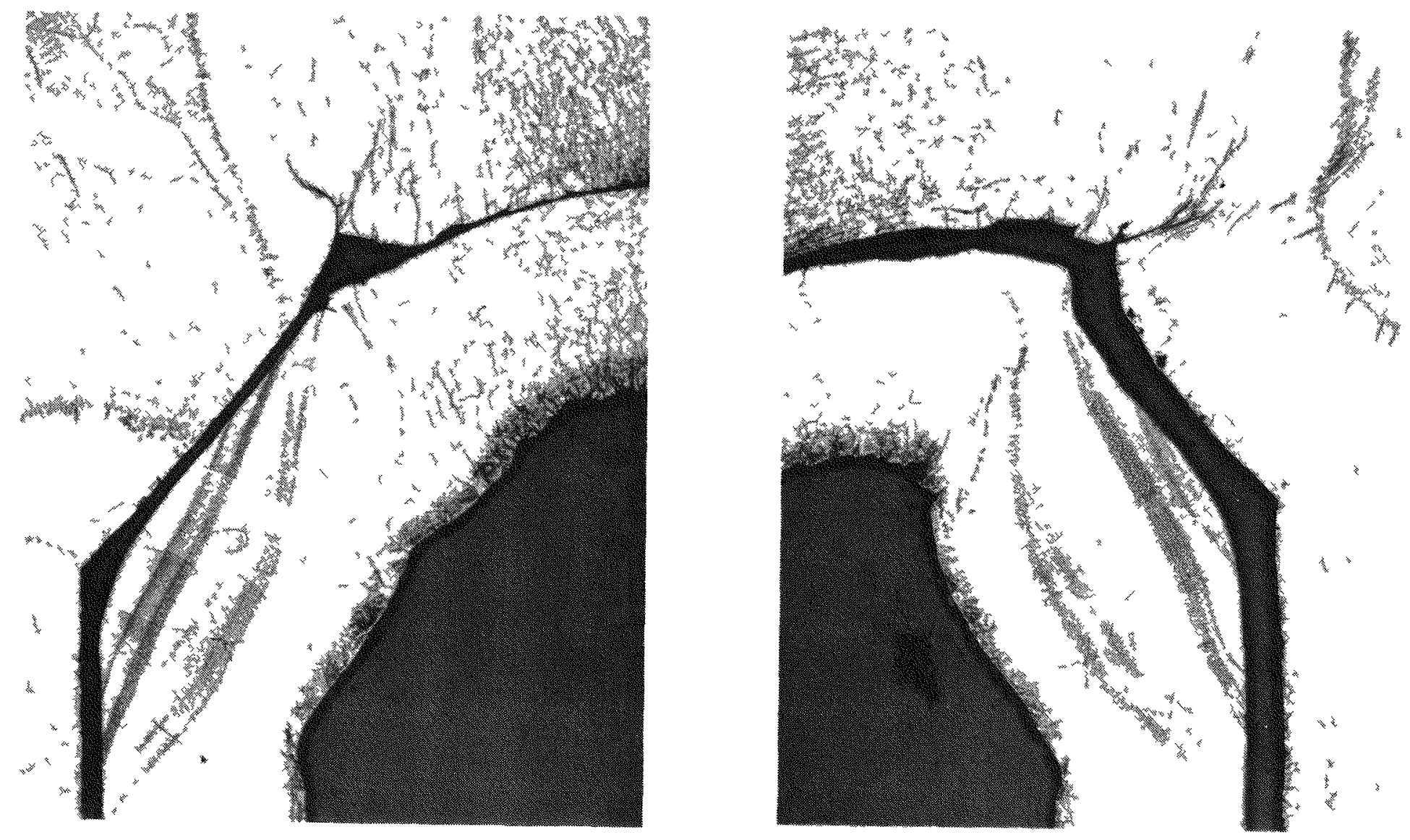


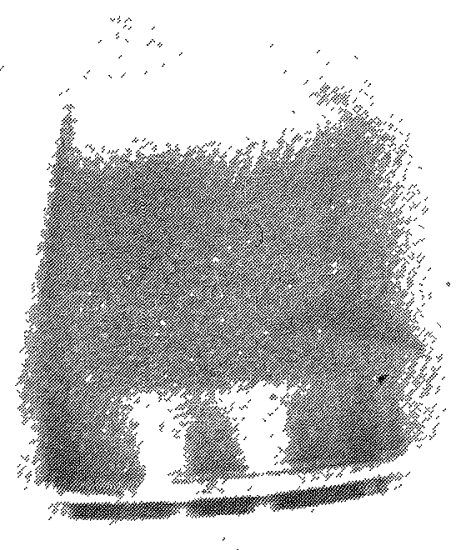

FIGURE 9 - WMT-11 clad after first impact (side only). Clad was not breached.

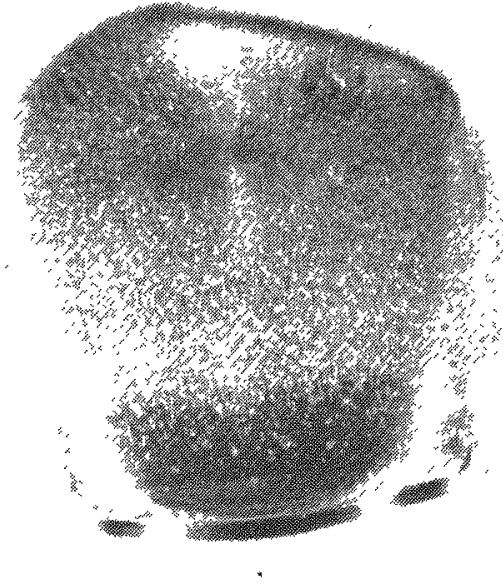

FIGURE 10 - WMT-11 clad after double impact. Clad was not breached.

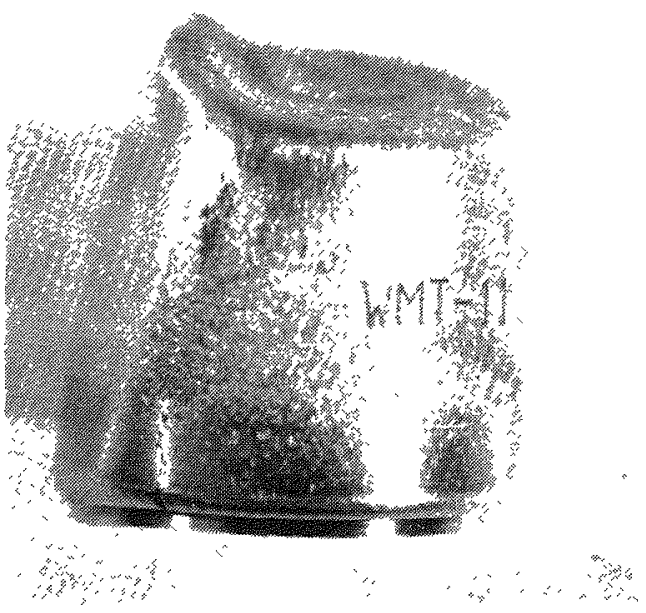

FIGURE 11 - WMT-11 after a side was impacted at $80.4 \mathrm{~m} / \mathrm{sec}$ and the dome at 78.8 $\mathrm{m} / \mathrm{sec}$. 


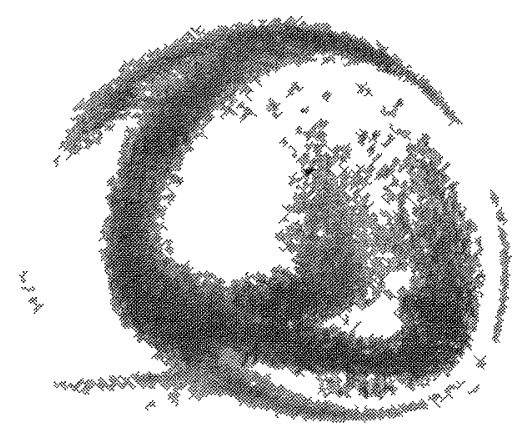

FIGURE 12 - Dome of WMT-11 clad after double impact. Clad was not breached.

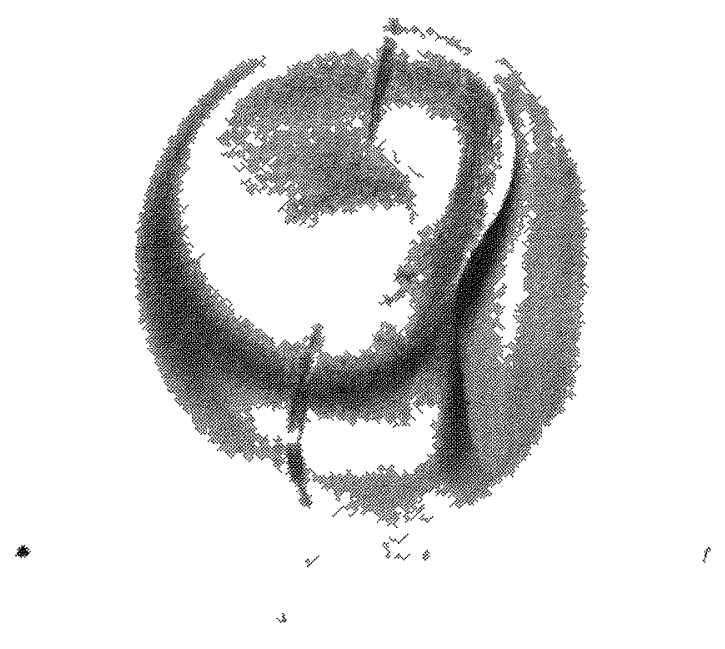

FIGURE 14 - Dome of WMT-11 strength member after double Impact Strength member was not breached.

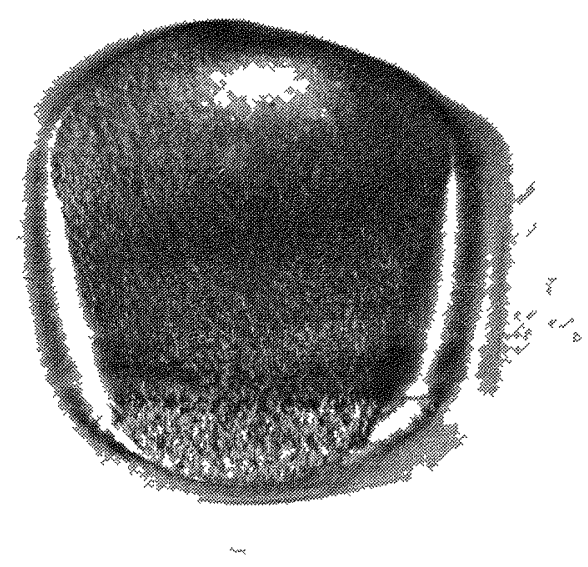

FIGURE 13 - Side view of WMT-11 strength member after double impact. Strength member was not breached.

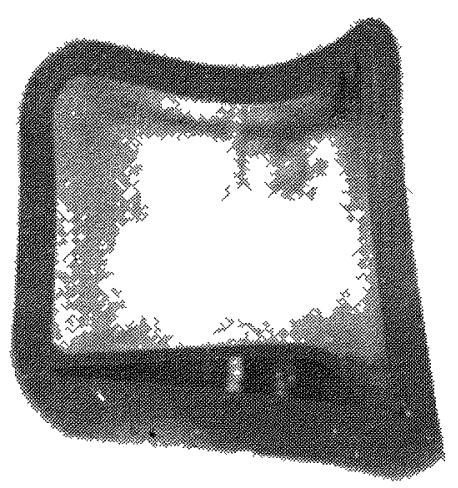

FIGURE 15 - Cross-sectioned WMT-11 strength member and liner after double impact Liner breached at junction of side and dome impact faces. Strength member was not breached 


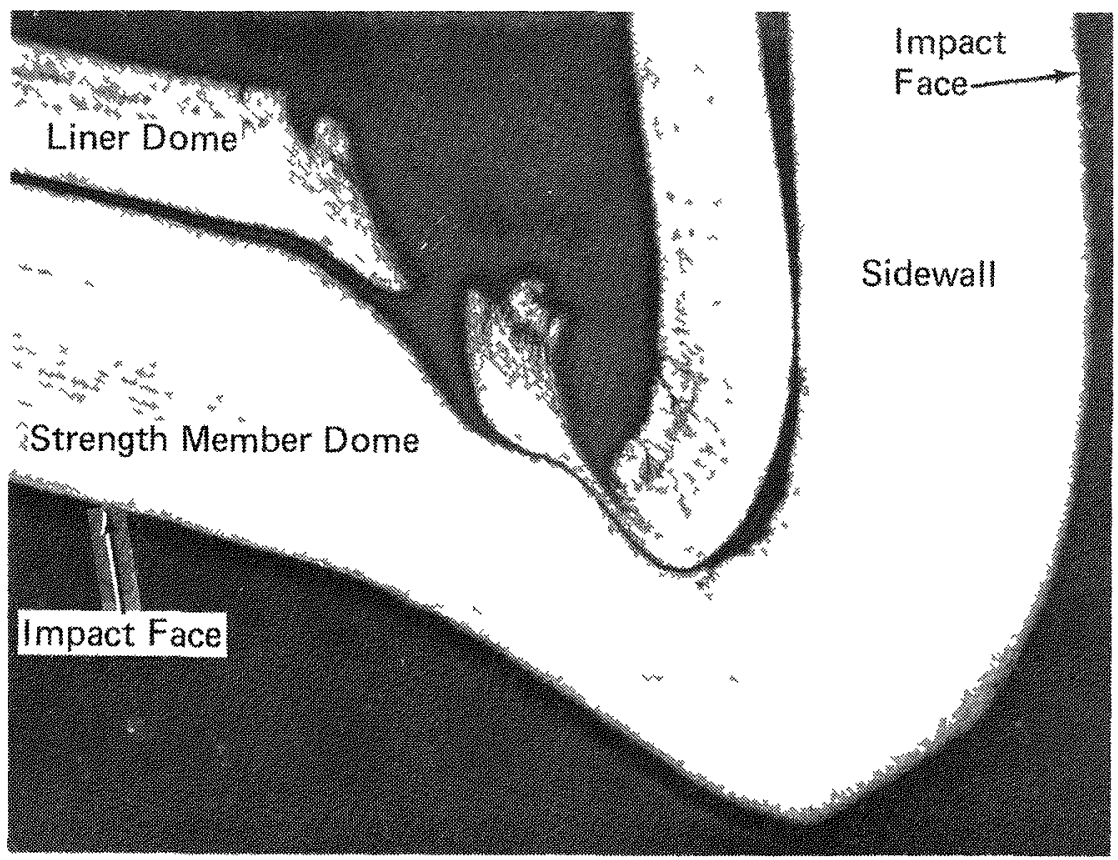

FIGURE 16 The liner of WMT 11 was the only liner breached during the double impact tests Falure occurred in the dome at the side/dome impact interface, after the side and dome each had been impacted at $\sim 80 \mathrm{~m} / \mathrm{sec}$ 

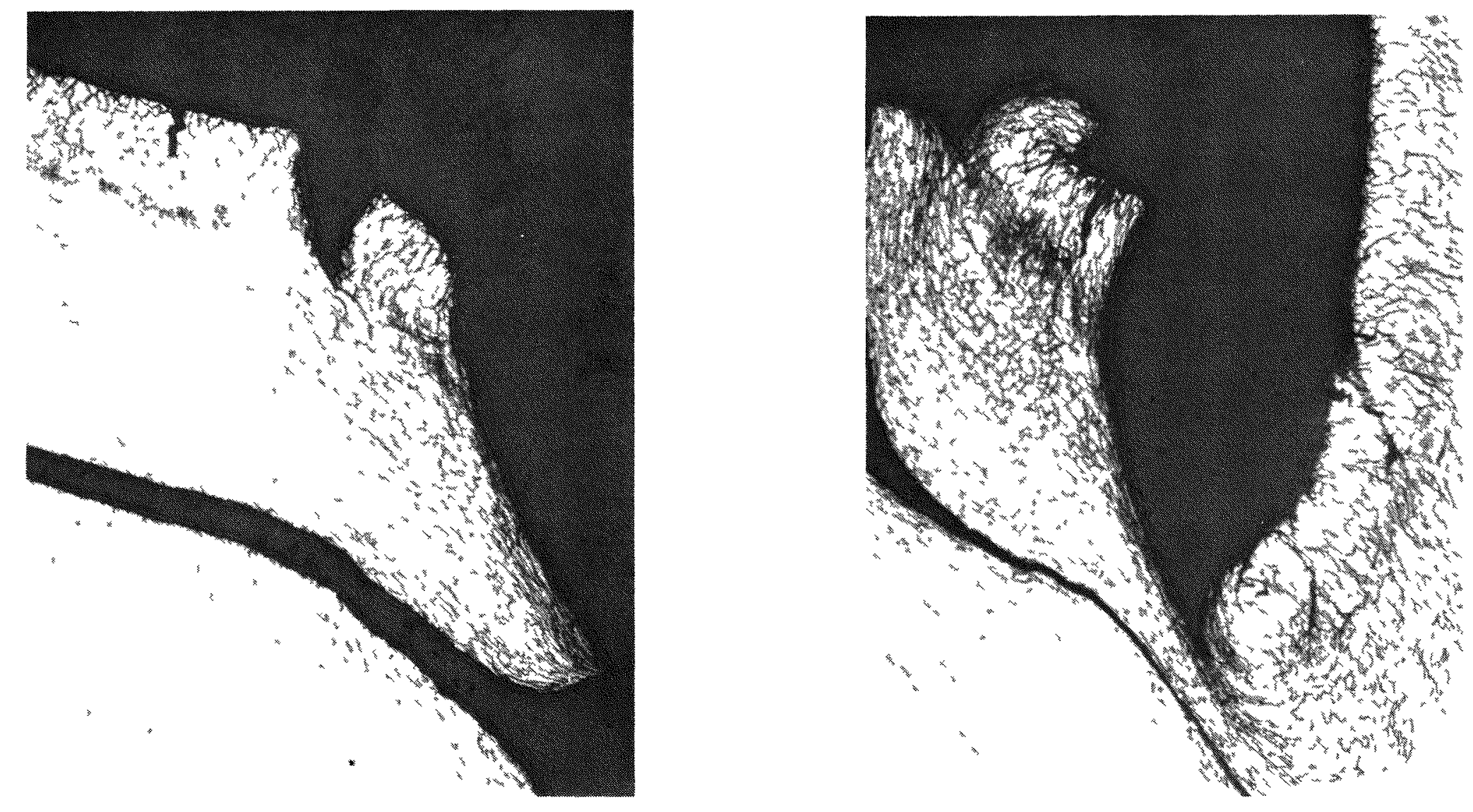


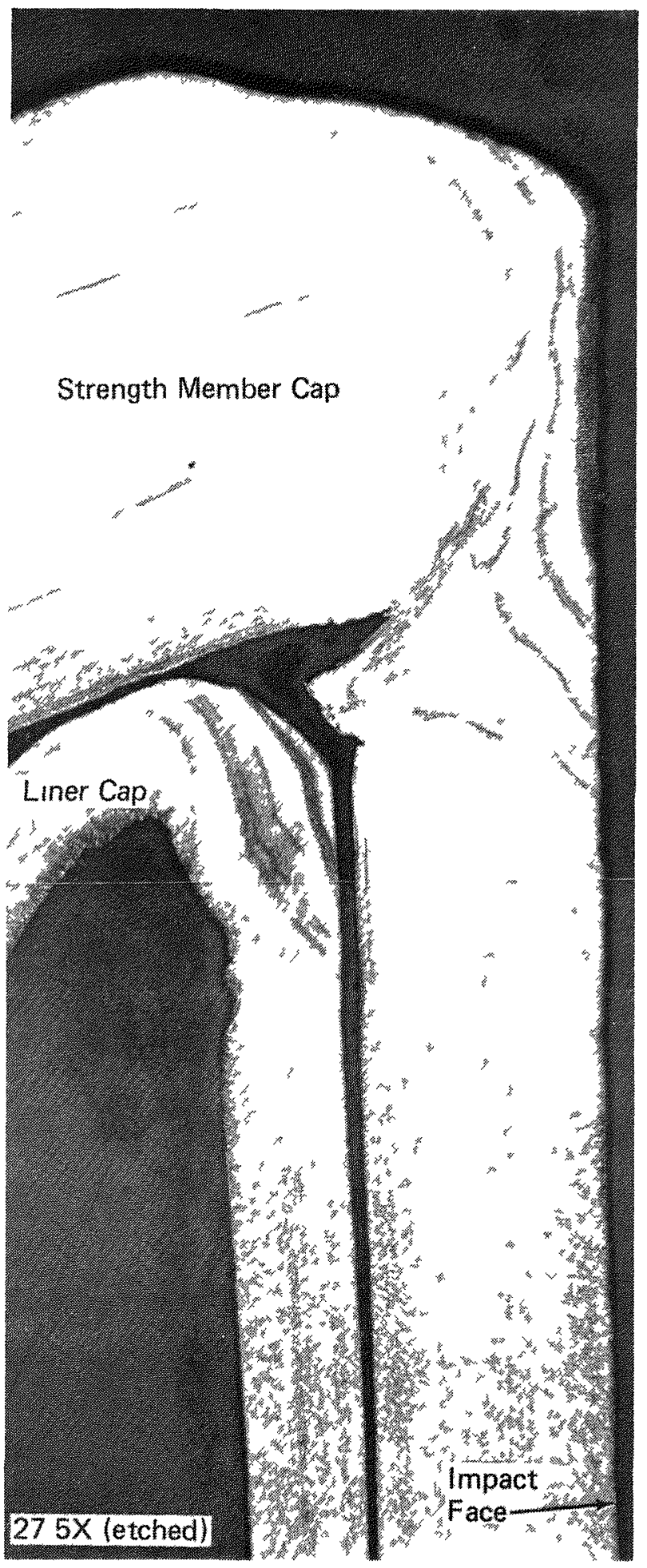

FIGURE 18 - Shear was initiated in WMT 11 186 mils into the cap side of the weld underbead in the strength member The side and dome of the capsule each had been $\mathrm{Im}$ pacted at $\sim 80 \mathrm{~m} / \mathrm{sec}$

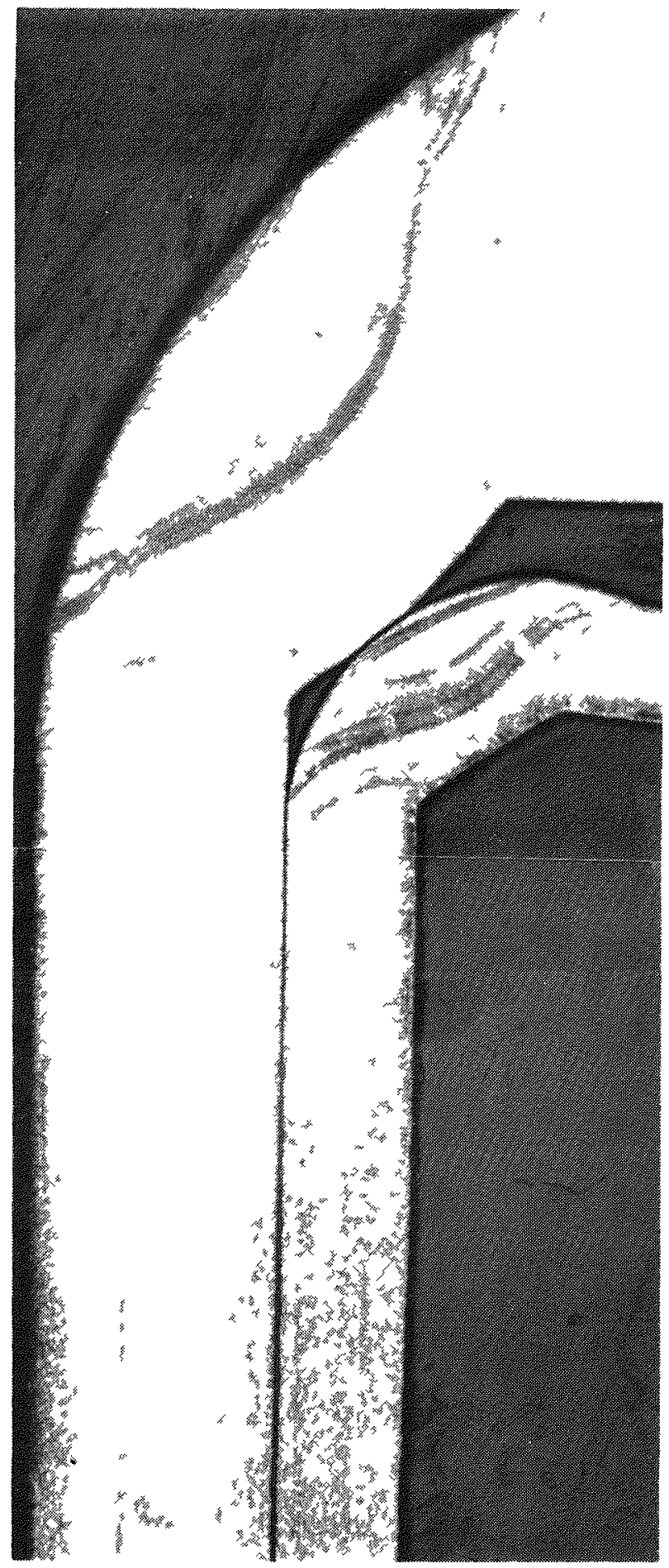

FIGURE 19 WMT 11 cross section of liner and strength member welds through impact face and $180^{\circ}$ of Impact (27 5X) 


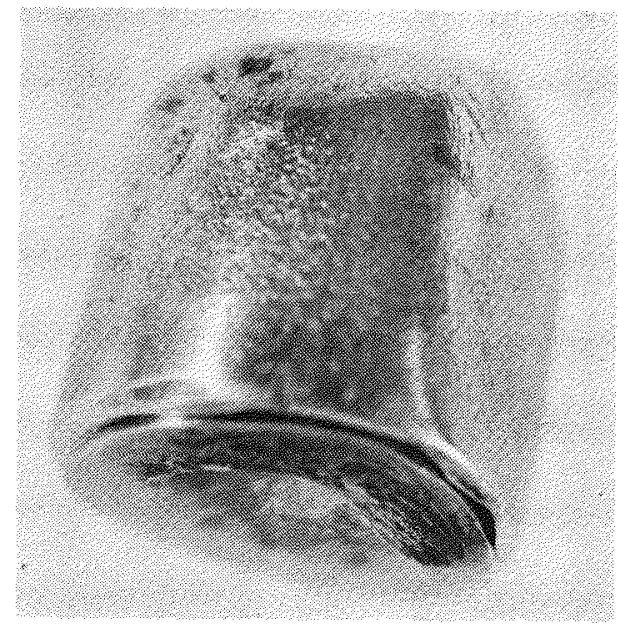

FIGURE 20 - Clad of WMT-12 after double impact. Corner impact overlapped only $\sim 50 \%$ of side impact, and impact angle appeared less than $45^{\circ}$. Small dent on weld (lower left) and dome corner are indicative of secondary hits following weld corner impact.

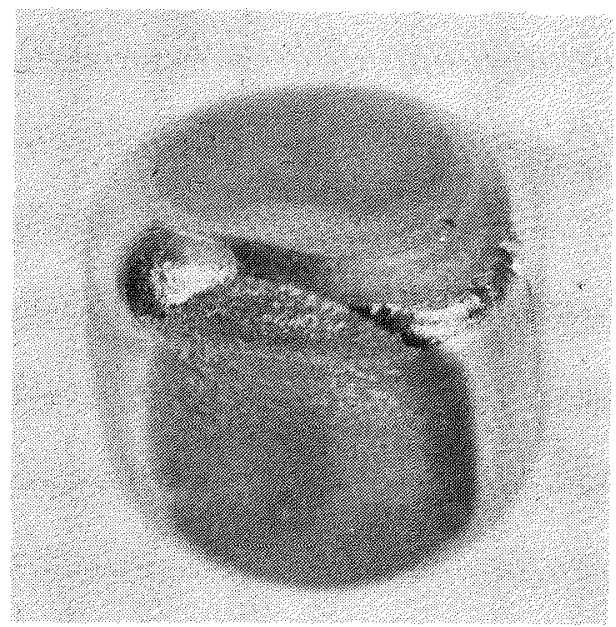

FIGURE 22 - WMT-12 strength member was not breached. Photo shows overlap of impact surfaces (corner and side).

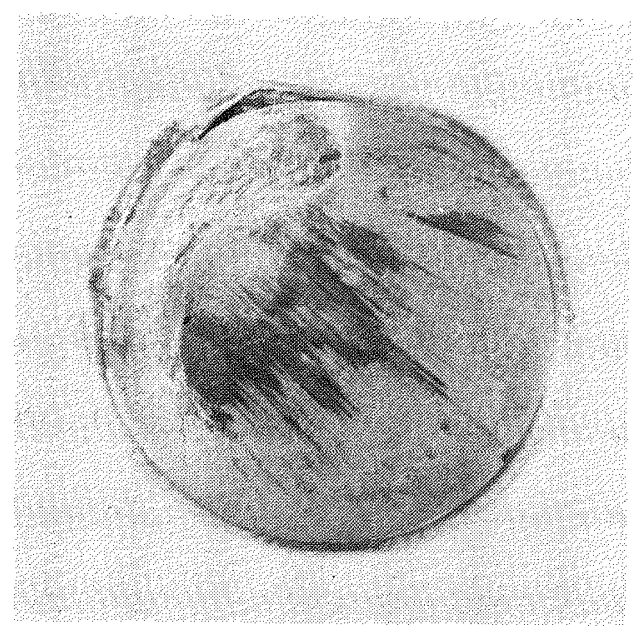

FIGURE 21 - Clad cap of WMT-12 after second impact. Breach in clad $\sim 8 \mathrm{~mm}$ long was located along the cap side of the weld in overlap of impact surfaces.

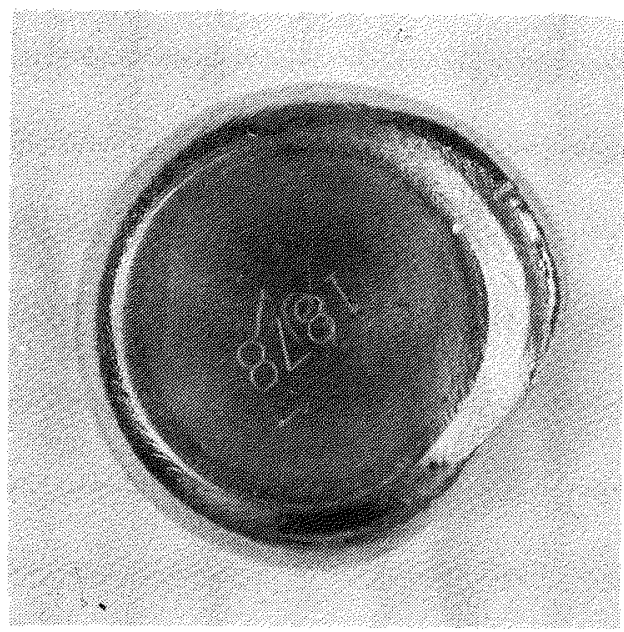

FIGURE 23 - WMT-12 strength member after double impact. Strength member was not breached. 


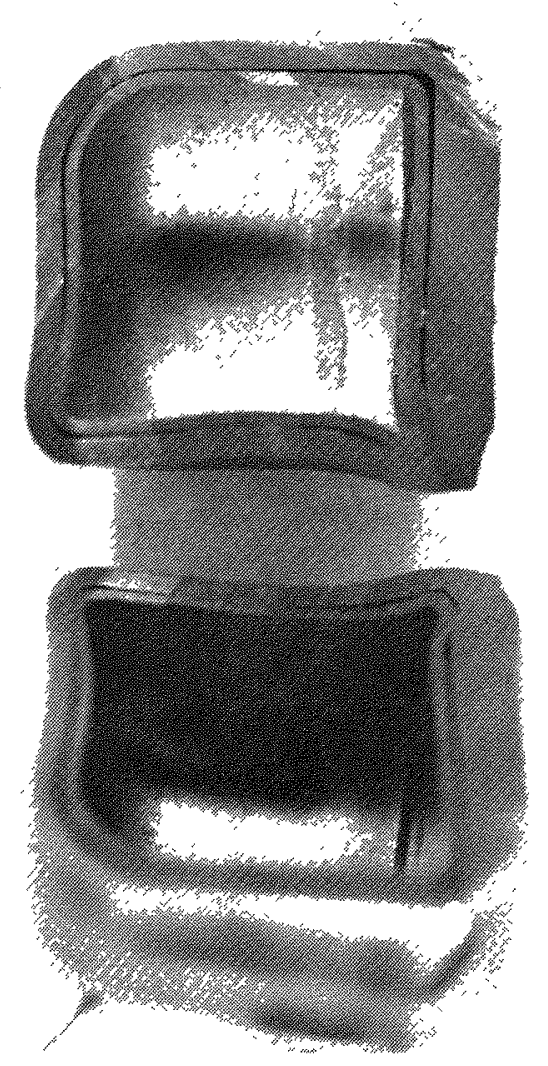

FIGURE 24 - Cross-sectioned WMT-12 strength member and liner after double impact; not breached.
FIGURE 25 - Cross-sectioned WMT-12 strength member and liner after double impact (side and corner); not breached. 

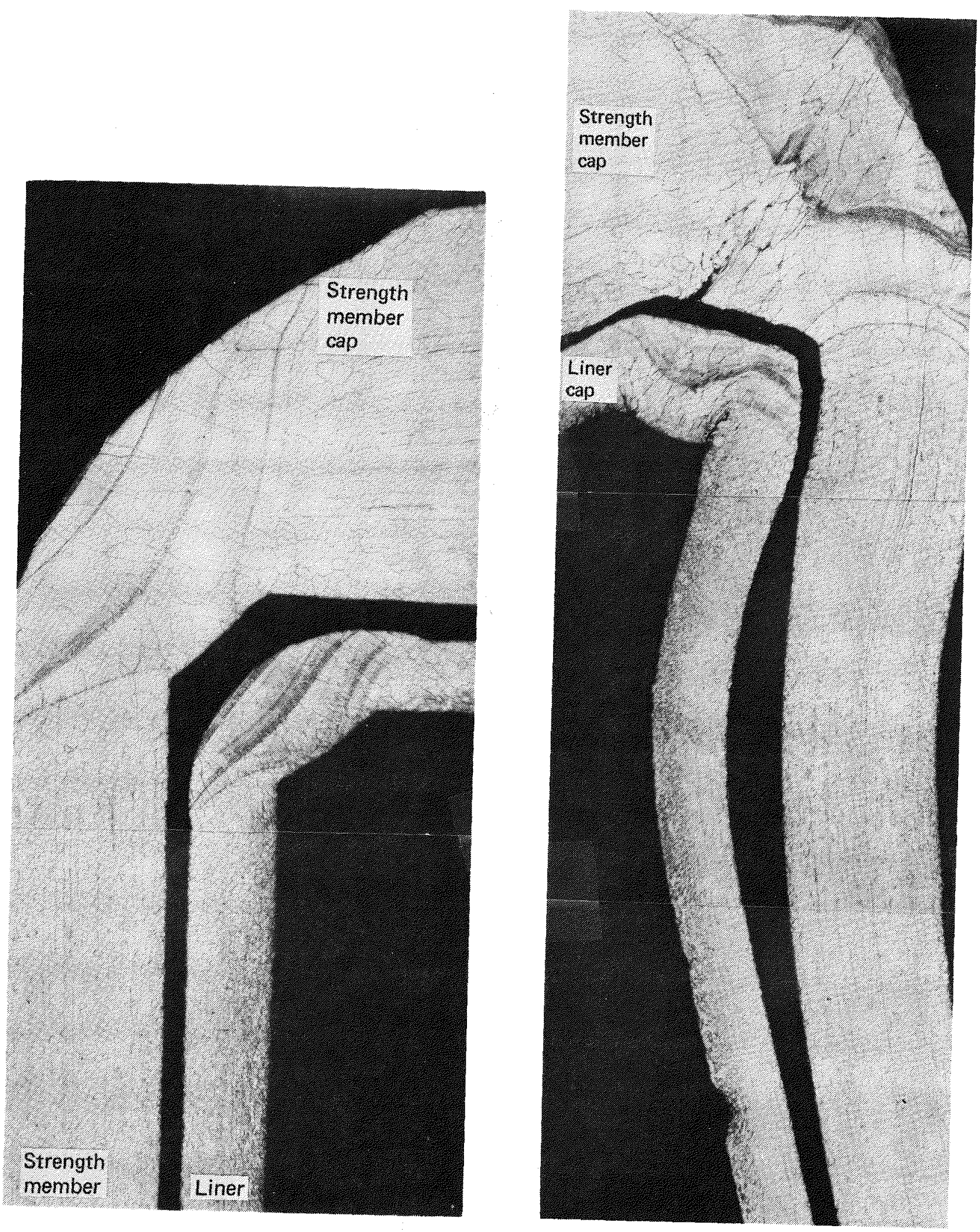

FIGURE 26 - WMT-12 cross section of liner and strength member welds through impact face and $180^{\circ}$ of impact. Metallographic examination revealed an indentation in liner side wall caused by the shim and folds in weld underbead of liner. Note also beginning of tear in strength member 


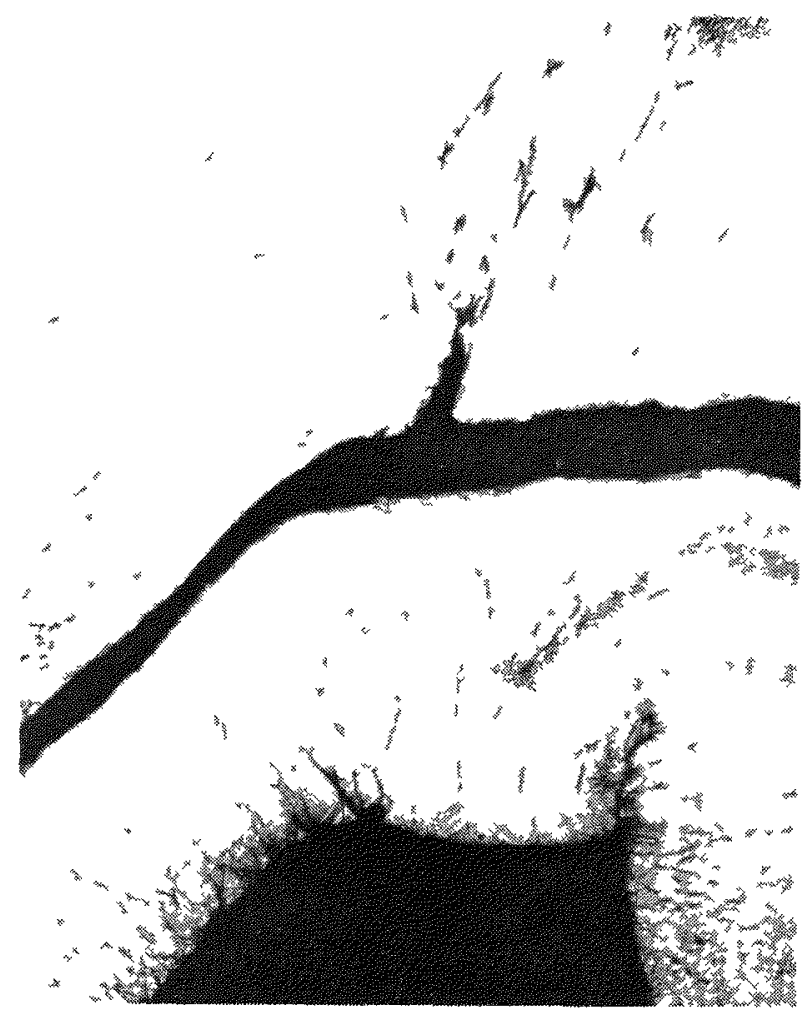

FIGURE 27 - Higher magnification (50X) of WMT-12 shows folds in liner and tear $(\sim 10.7$ mils deep) in strength member.

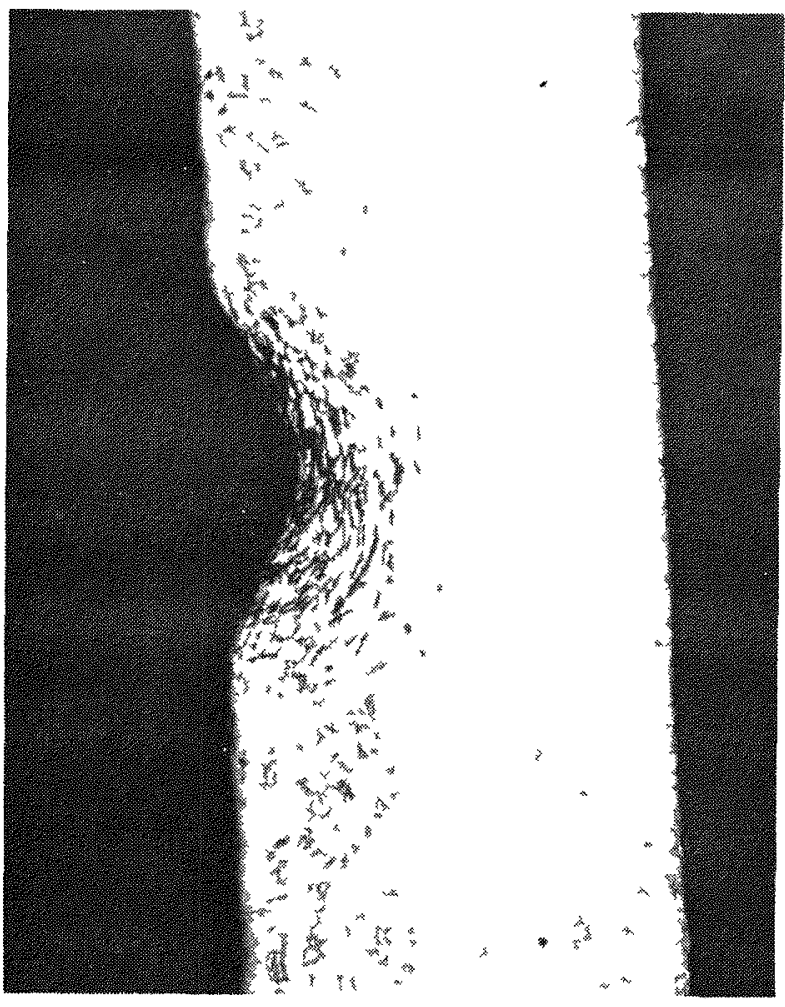

FIGURE 28 - Higher magnification (100X) of WMT-12 showing indentation in liner sidewall caused by shım. 


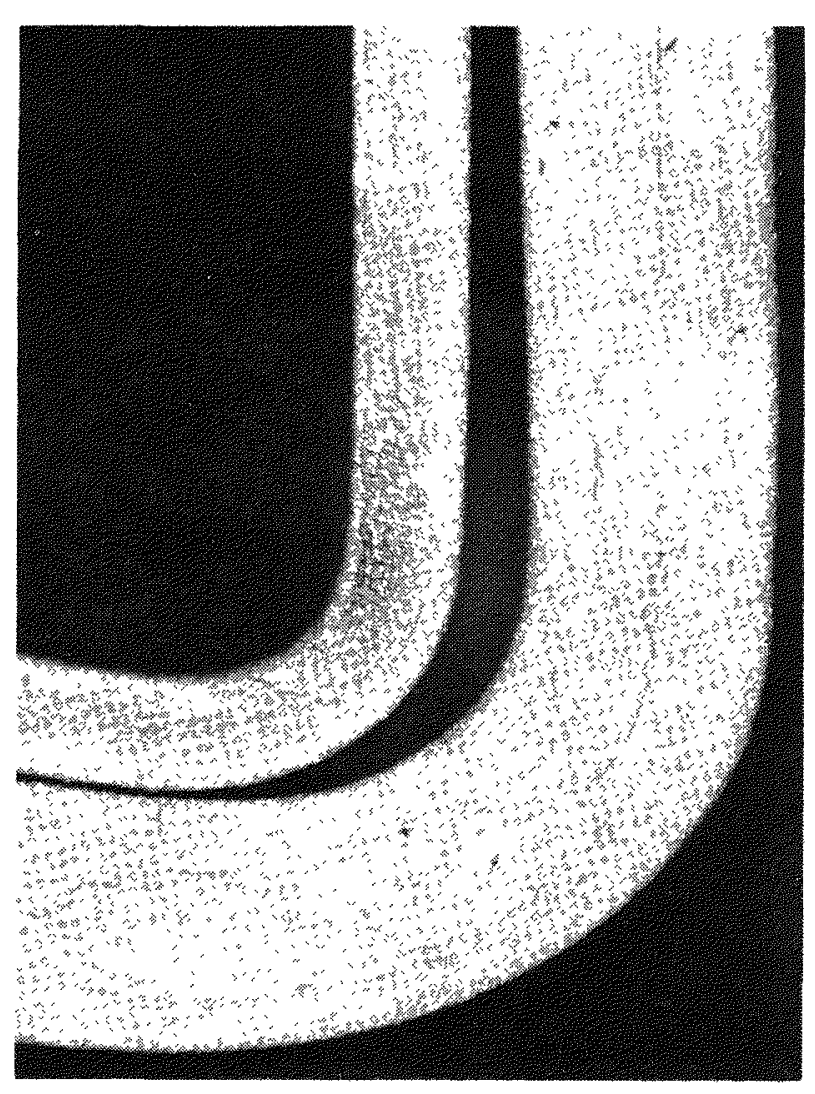

FIGURE 29 - WMT-12 (27.5X) cross section of liner and strength member impact face on dome end.

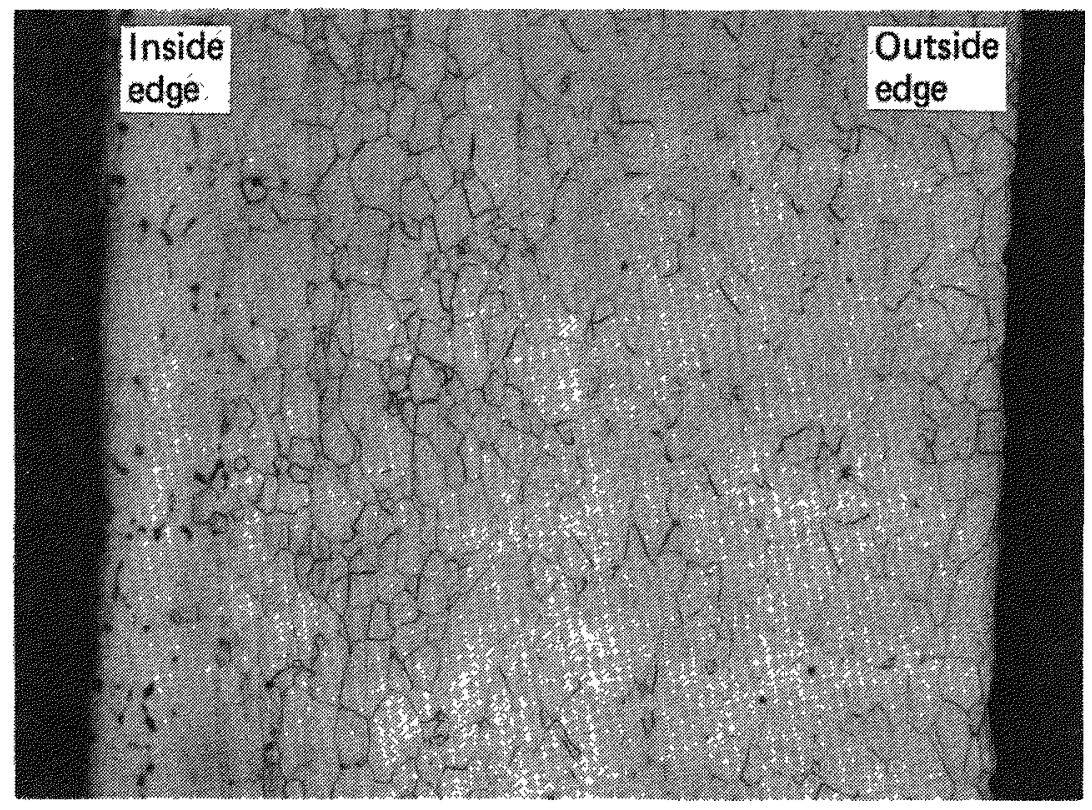

FIGURE 30 - Liner side wall of WMT-12. Grain structure along the inside edge was indicative of embrittlement by oxygen. (200X) 

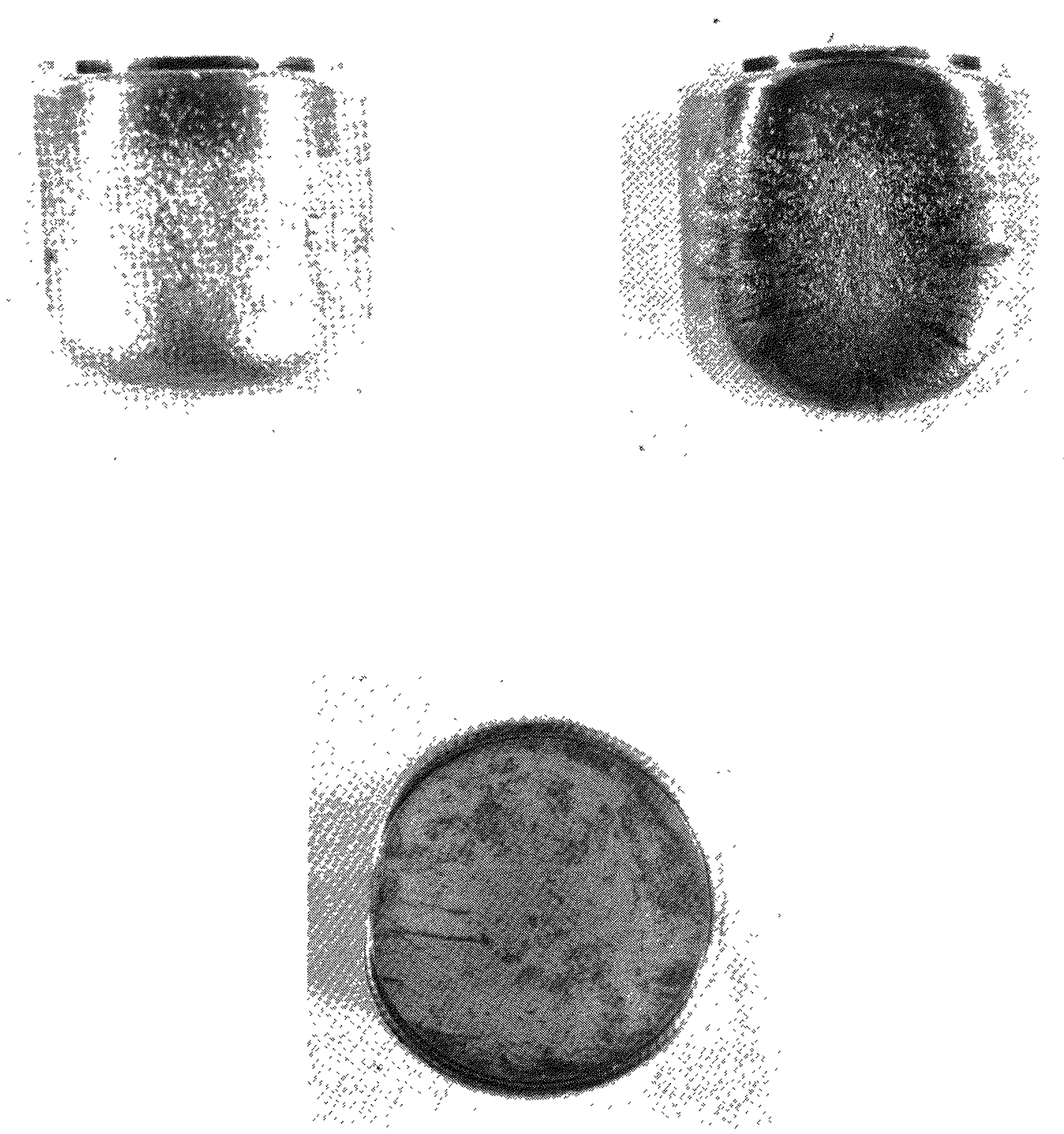

FIGURE 31 - Three views of WMT-13 showing condition of clad after first side impact at 81.4 $\mathrm{m} / \mathrm{sec}$. Clad was not breached. 


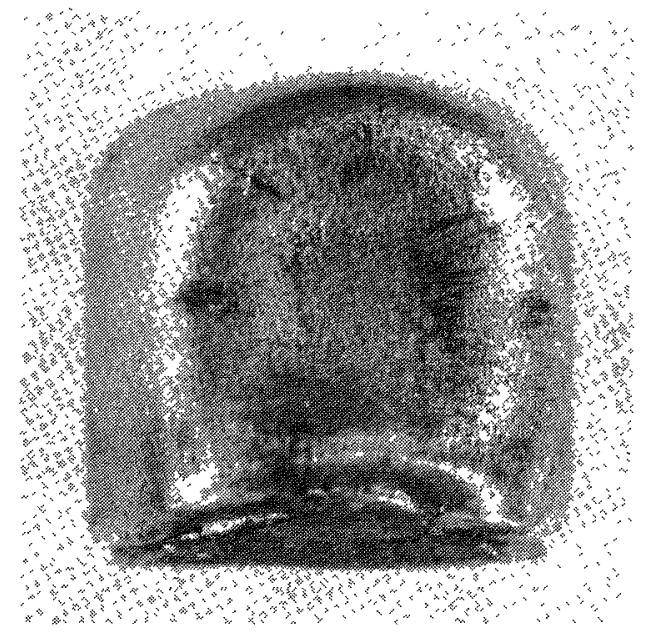

FIGURE 32 - WMT-13 after a side was impacted at $81.4 \mathrm{~m} / \mathrm{sec}$ and the weld corner at $81.5 \mathrm{~m} / \mathrm{sec}$. Clad was not breached.

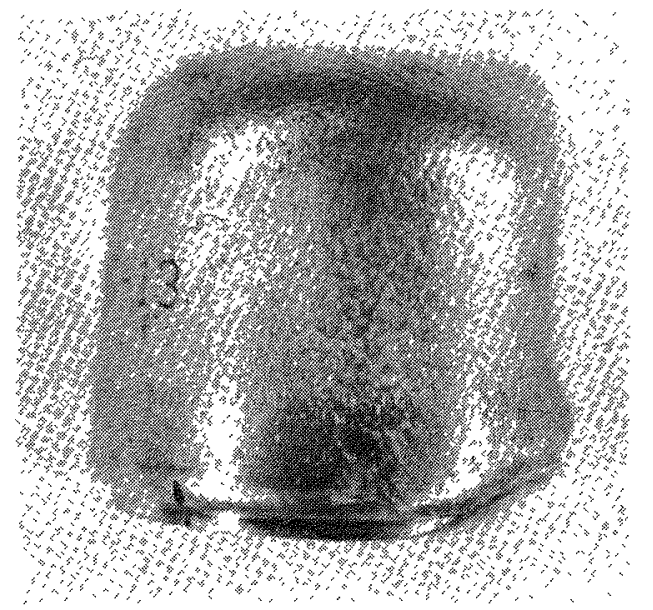

FIGURE 34 - Side view of WMT-13 clad after second impact (side and corner). Clad was not breached.

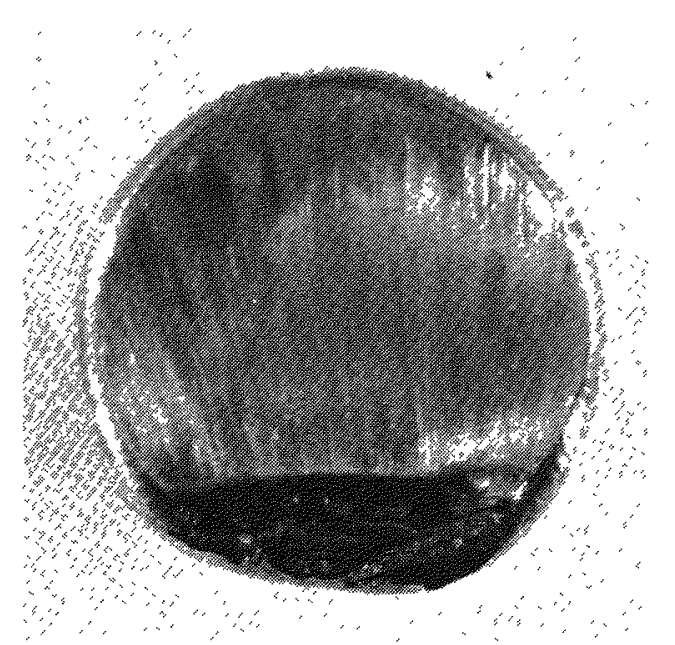

FIGURE 33 - Clad cap of WMT-13 showing location of second impact. Clad was not breached.

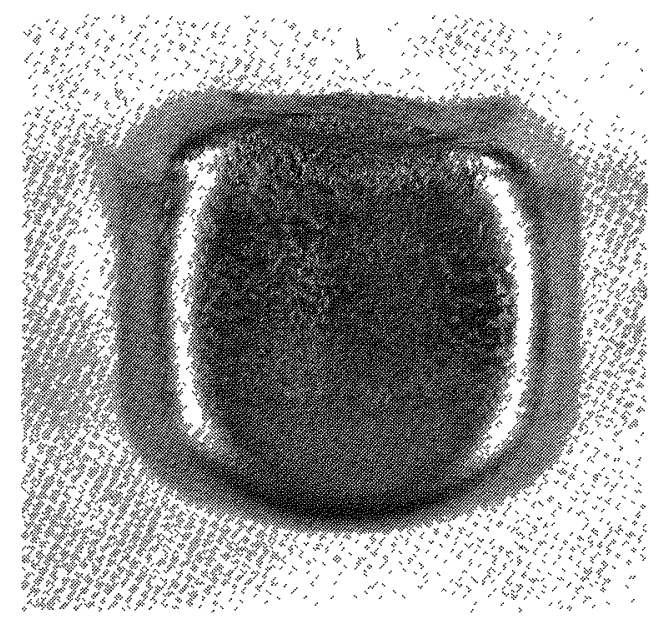

FIGURE 35 - Side view of WMT-13 strength member after double impact (side and corner). Strength member was not breached. 


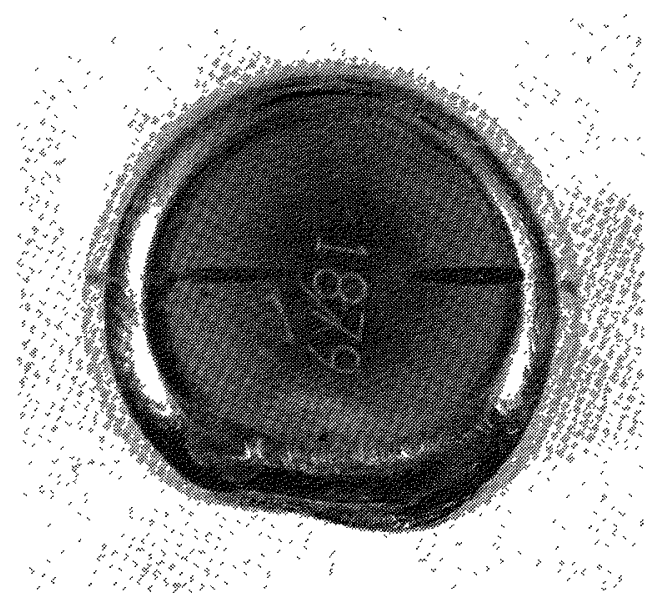

FIGURE 36 - WMT-13 strength member cap after double impact (side and corner). Strength member and clad were not breached. Cut across cap occurred during removal of clad.

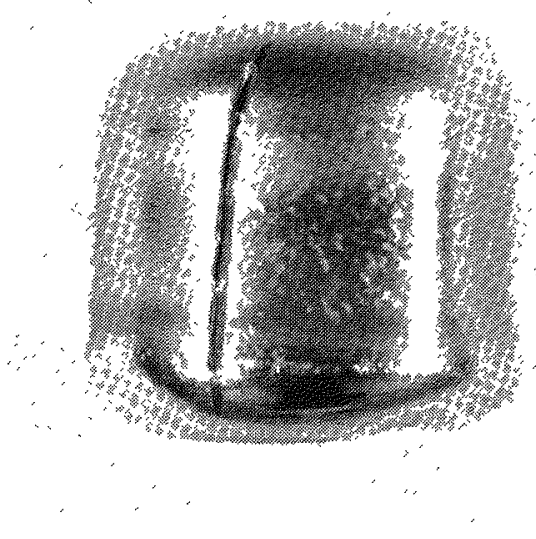

FIGURE 37 - Side view of WMT-13 strength member after double impact (side and corner); neither breached. Cut in side occurred during removal of clad.

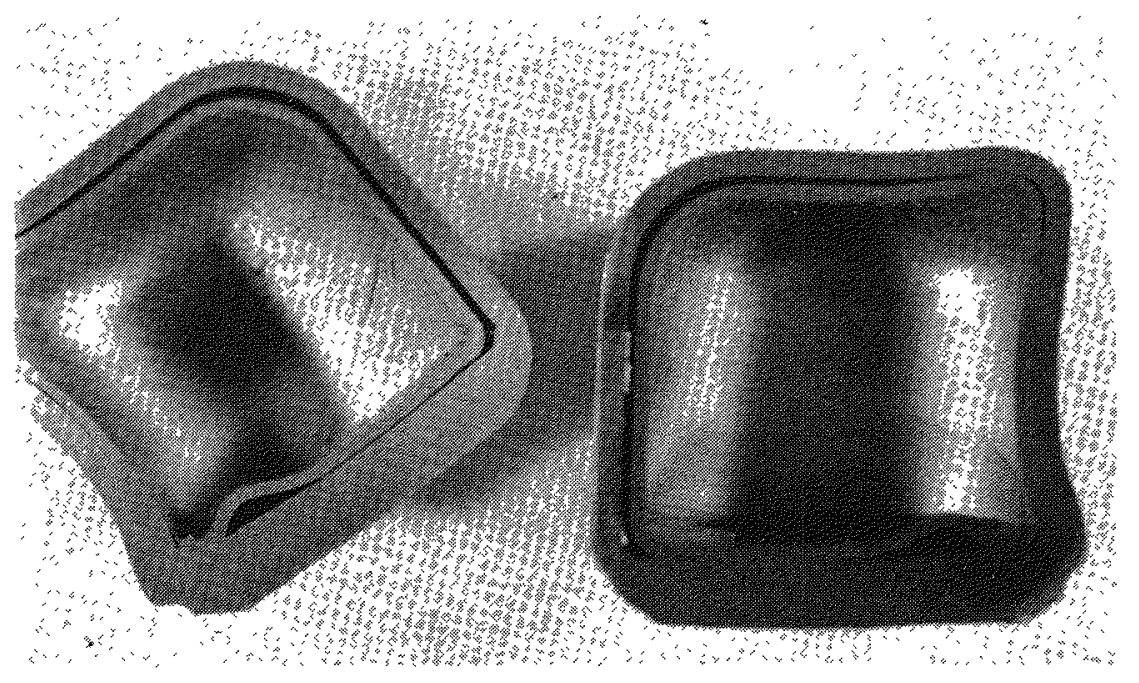

FIGURE 38 - Cross-sectioned

WMT-13 strength member and liner after double impact; neither breached. 

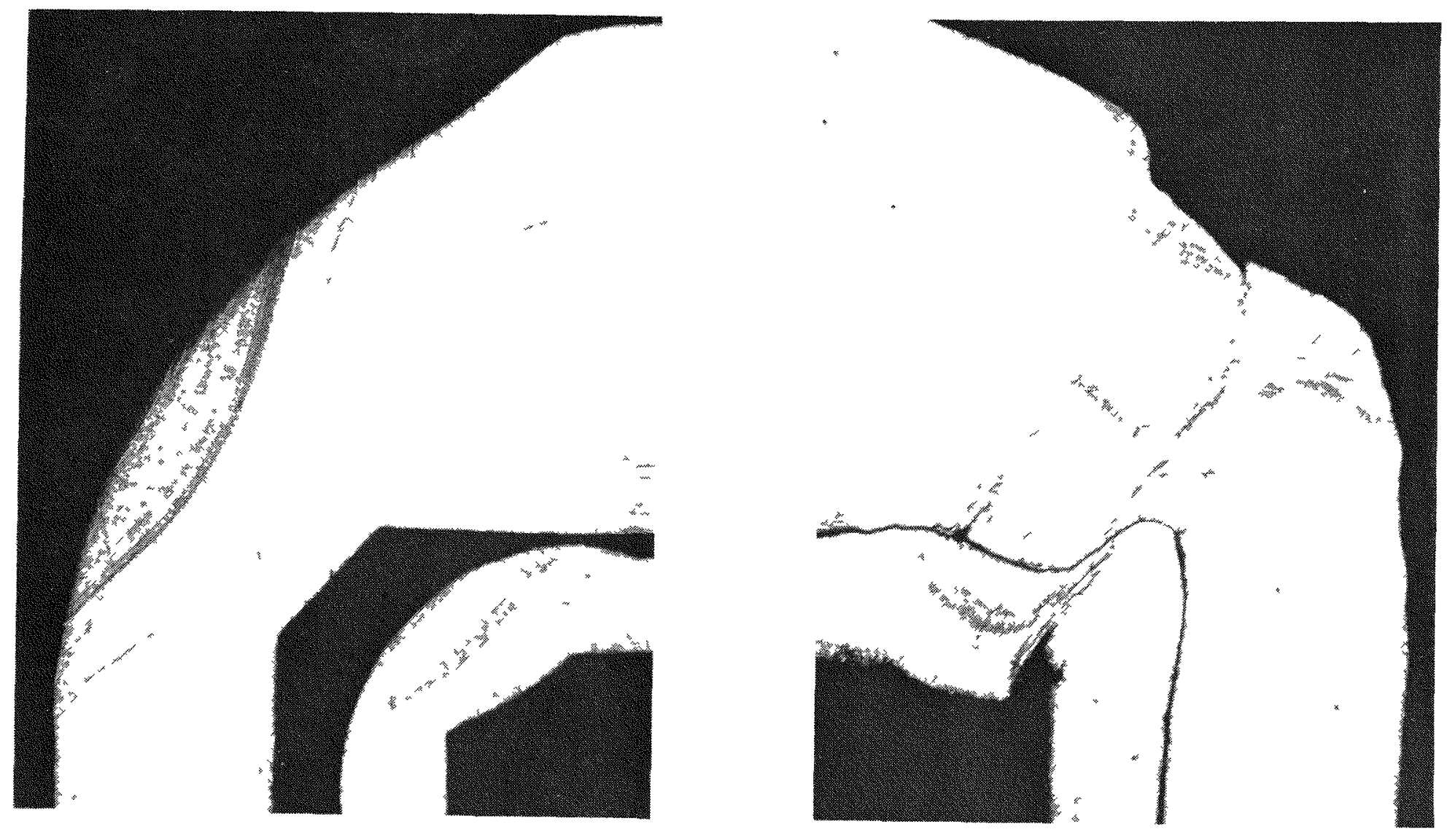
FIGURE $39-$ WMT -13 cross section of liner and strength member welds through impact face and
$180^{\circ}$ of impact. $(27.5 \mathrm{X})$ 


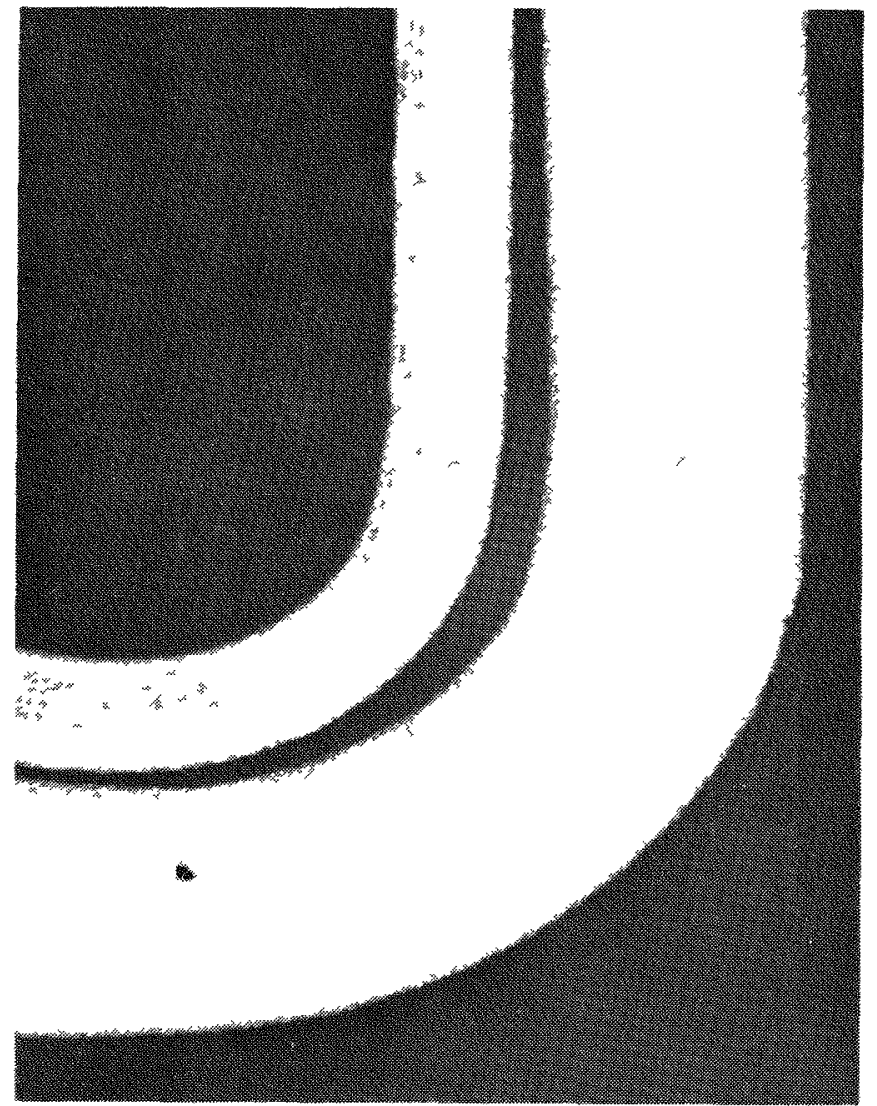

FIGURE 40 - WMT-13 cross section of liner and strength member dome end on impact face. $(27.5 \mathrm{X})$

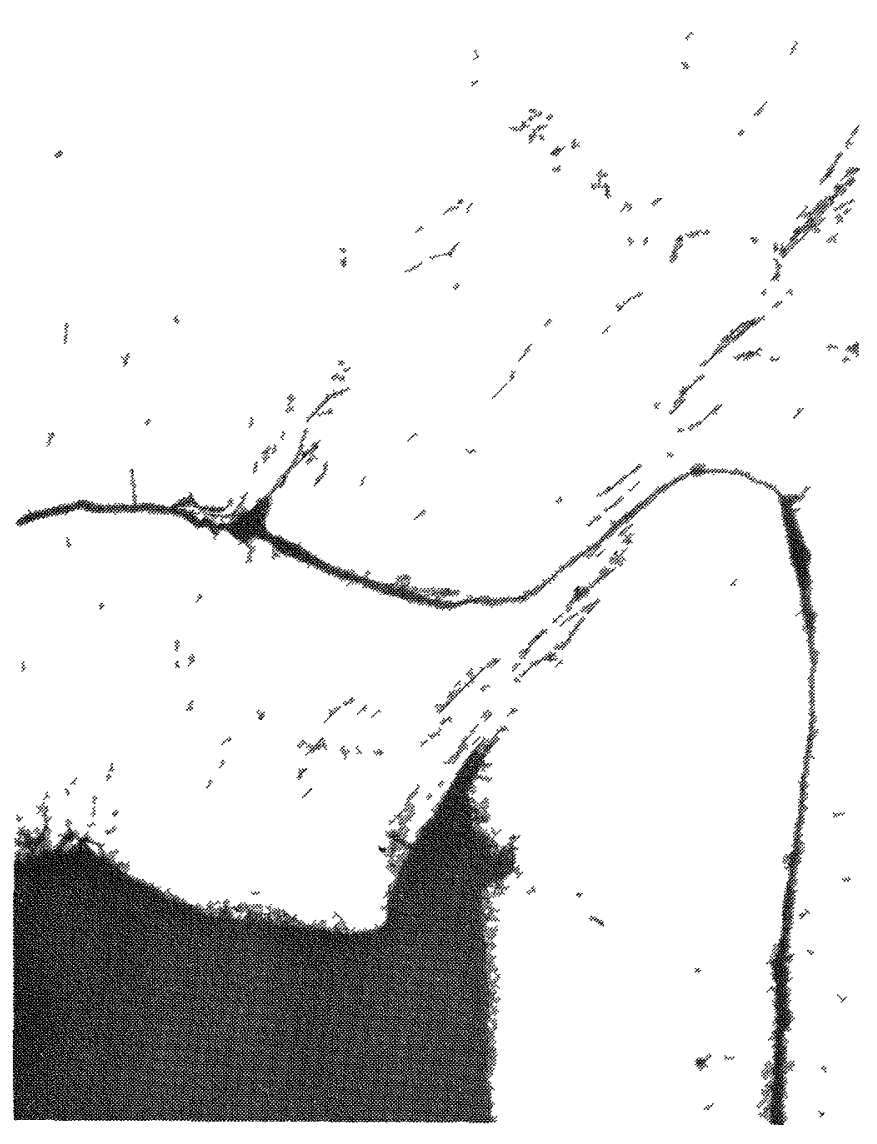

FIGURE 41 - WMT-13 cross section of liner weld on impact face. Note shear stress

through liner and strength member welds. (50X) 


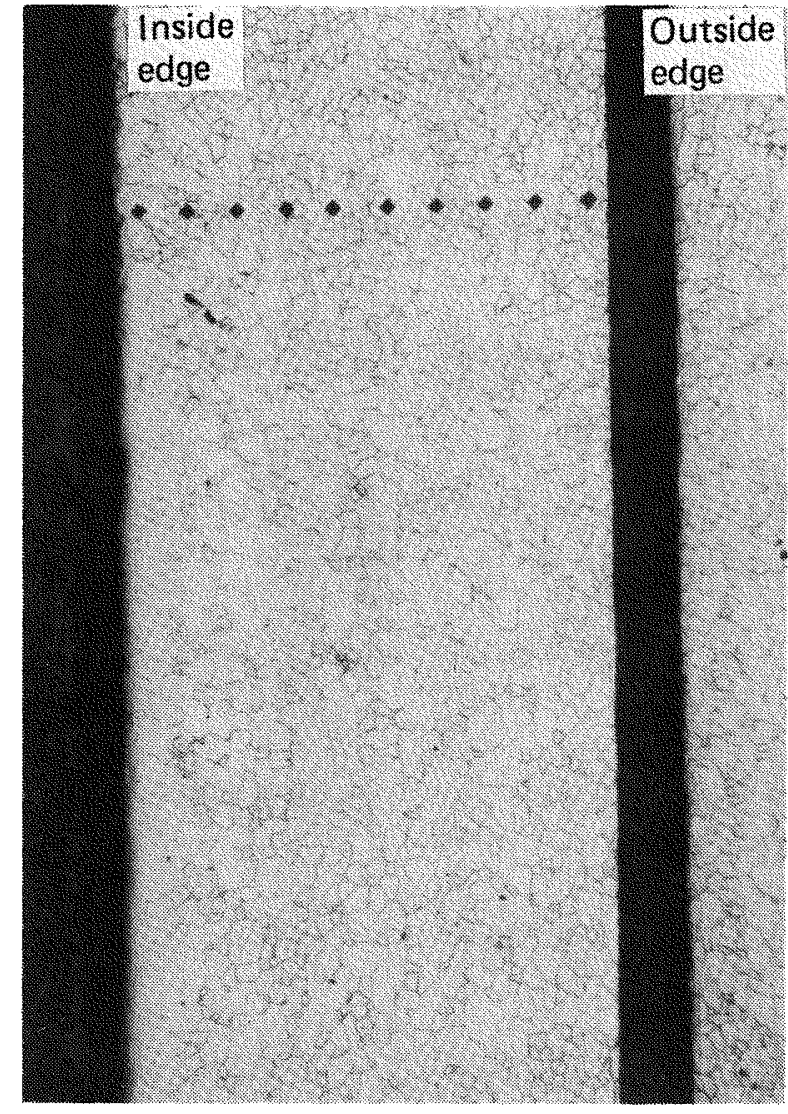

FIGURE 42 - Cross section of WMT-13 liner cap. Note variation of grain structure from inside to outside edge of both liner cap and liner side wall. (100X)

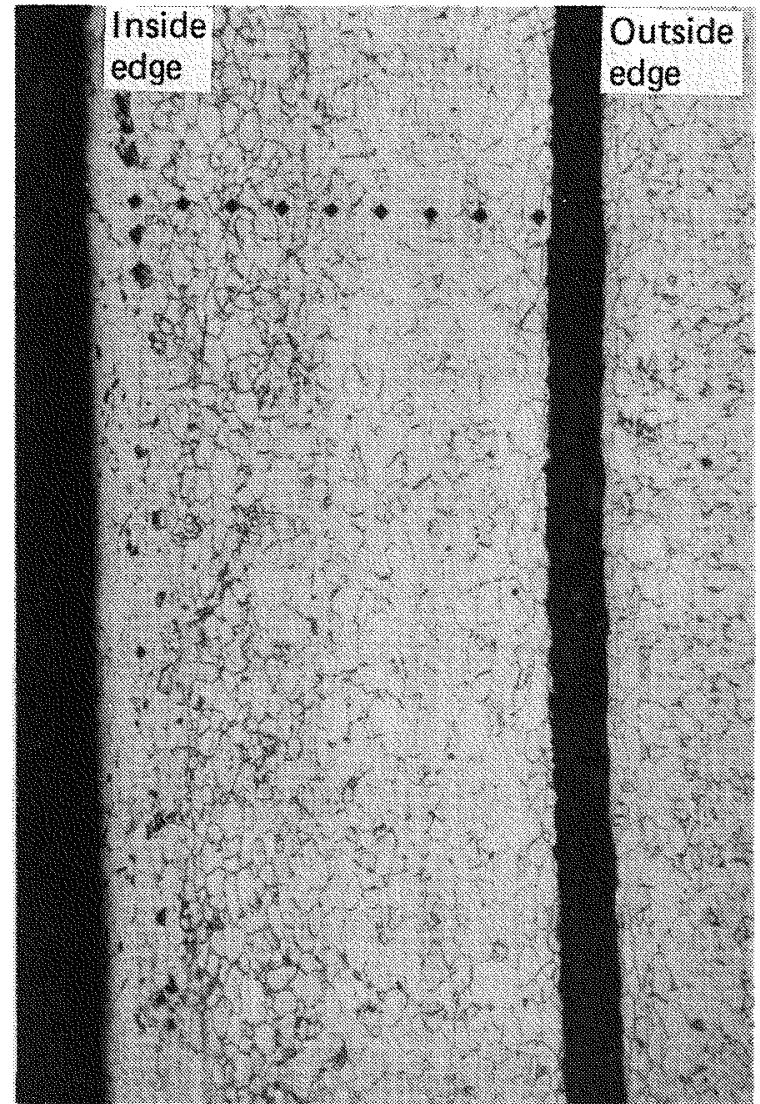

FIGURE 43 - Cross section of WMT-13 liner side wall. Note variation of grain structure from inside to outside edge of both liner cap and liner side wall. (100X) 

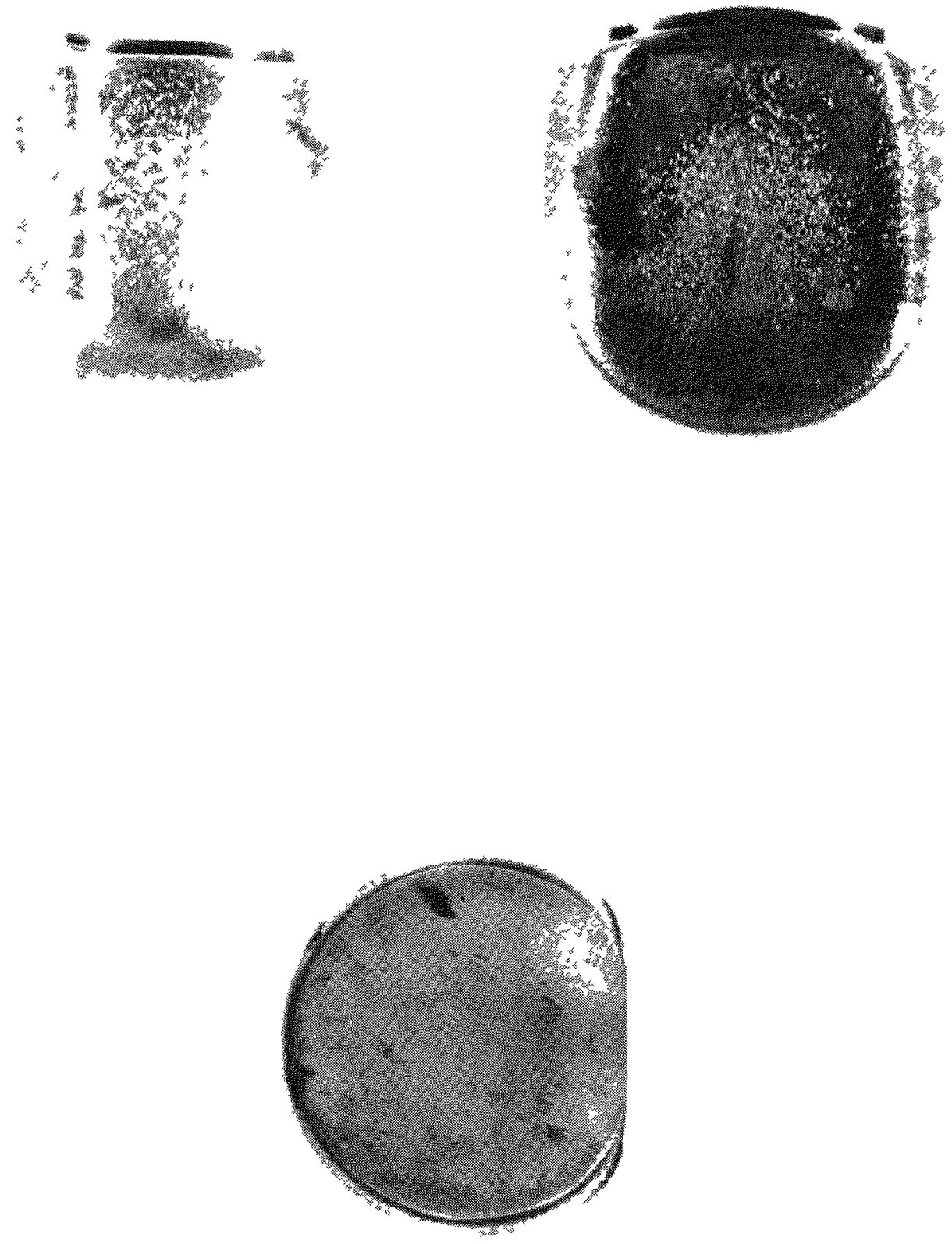

FIGURE 44 - Condition of WMT-14 clad after side impact at $105.3 \mathrm{~m} / \mathrm{sec}$. Clad was not breached. 


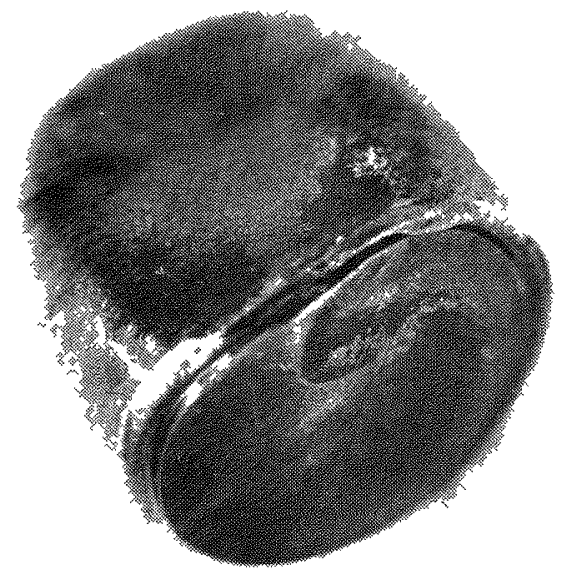

FIGURE 45 - WMT-14 clad after side/corner double impact. Clad breached. Second impact was not directly over first impact. (Side was impacted at $105.3 \mathrm{~m} / \mathrm{sec}$ and the weld corner was impacted at $104.0 \mathrm{~m} / \mathrm{sec}$.)

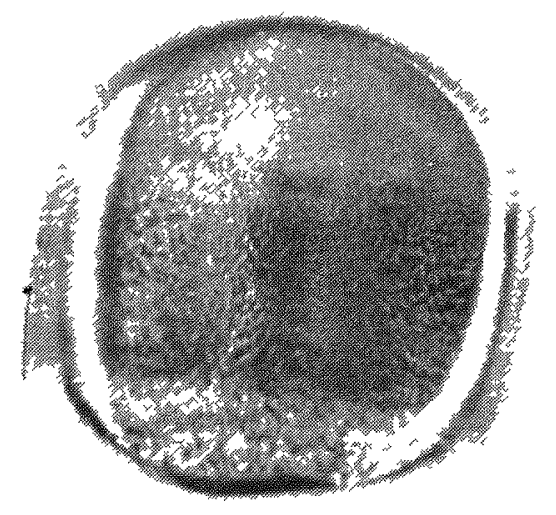

FIGURE 47 - Side view of WMT-14 strength member showing angles of double impacts. Strength member was not breached.

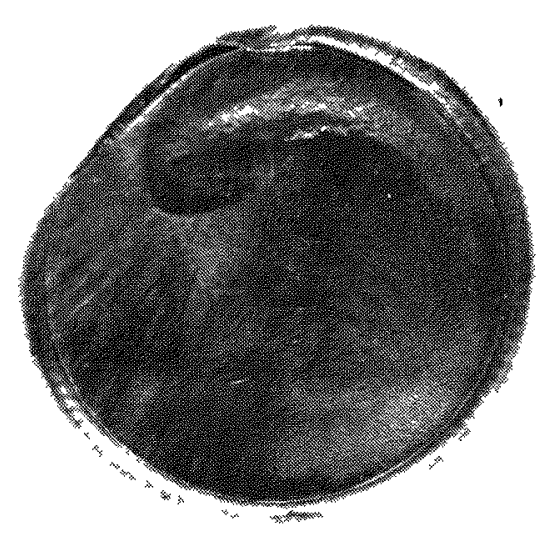

FIGURE 46 - WMT-14 clad cap after double impact. Clad was breached along cap side of weld for $\sim 6 \mathrm{~mm}$.

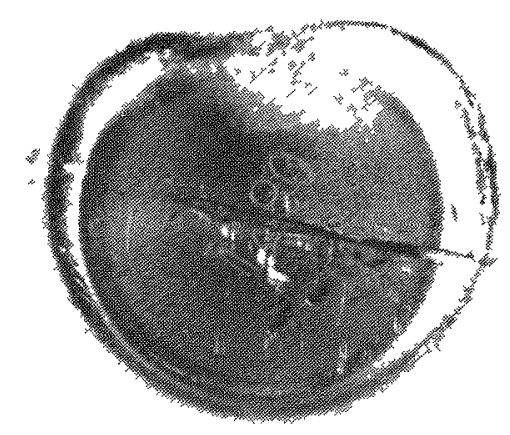

FIGURE 48 - WMT-14 strength member cap showing location of second impact. Strength member was not breached. Cut across cap occurred during clad removal. 


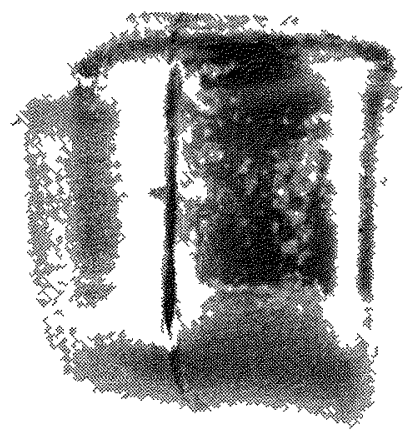

FIGURE 49 - WMT-14 strength member after double impact. Strength member was not breached. Vertical cut along side occurred during clad removal.

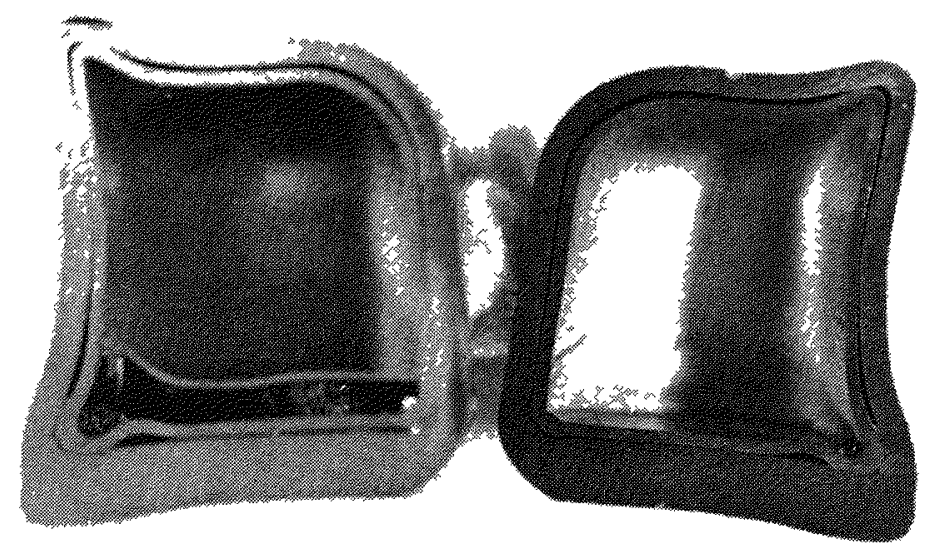

FIGURE 50 - Cross-sectioned WMT-14 strength member and liner after double impact (side and corner); nether breached. 

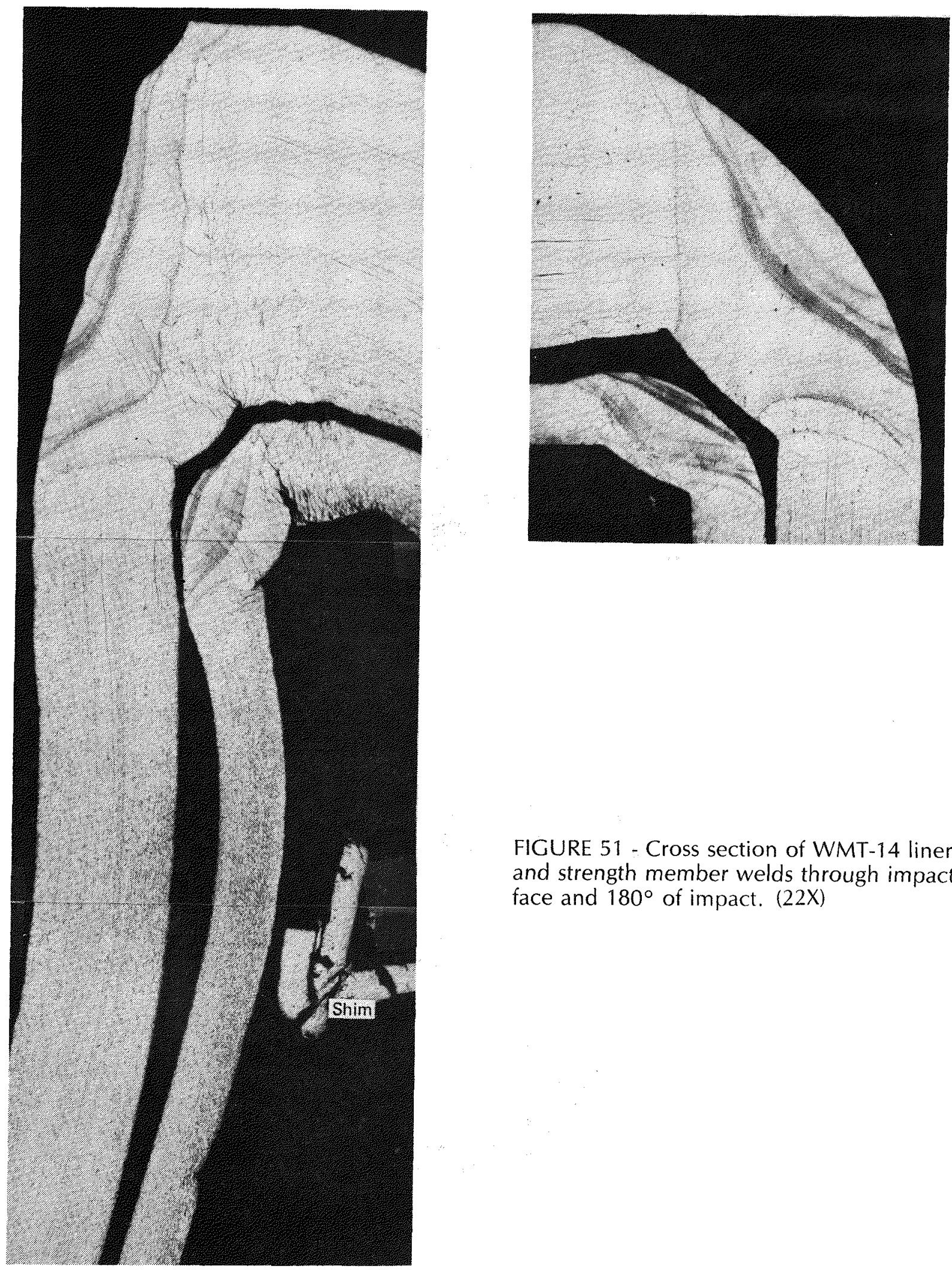

FIGURE 51 - Cross section of WMT-14 liner and strength member welds through impact face and $180^{\circ}$ of impact. (22X) 


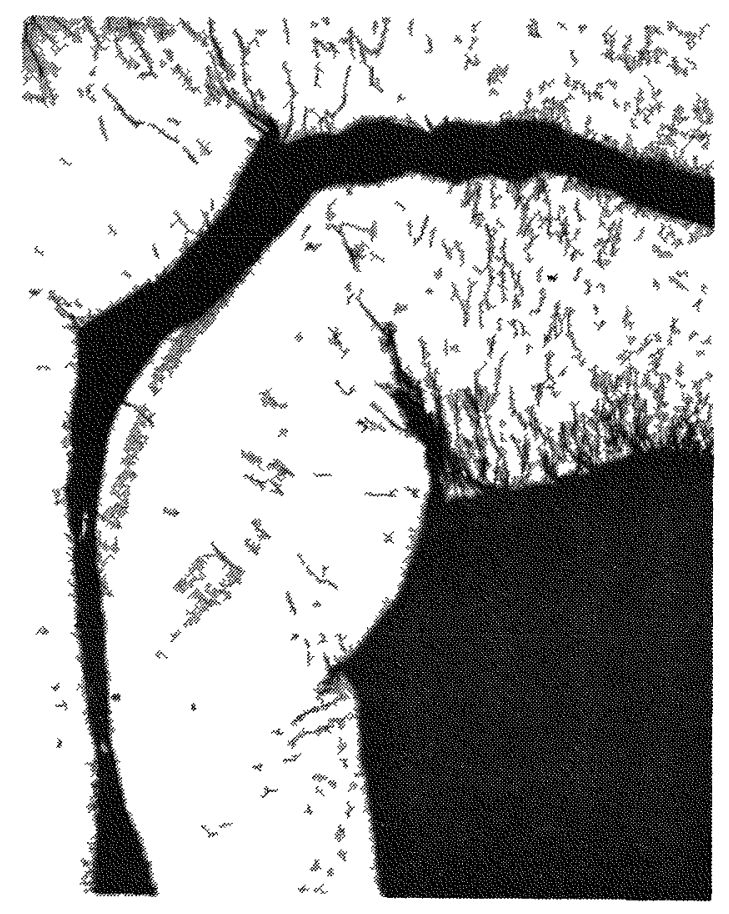

FIGURE 52 - WMT-14 liner and weld at impact face Note folding and compression of heat affected zone (50X)

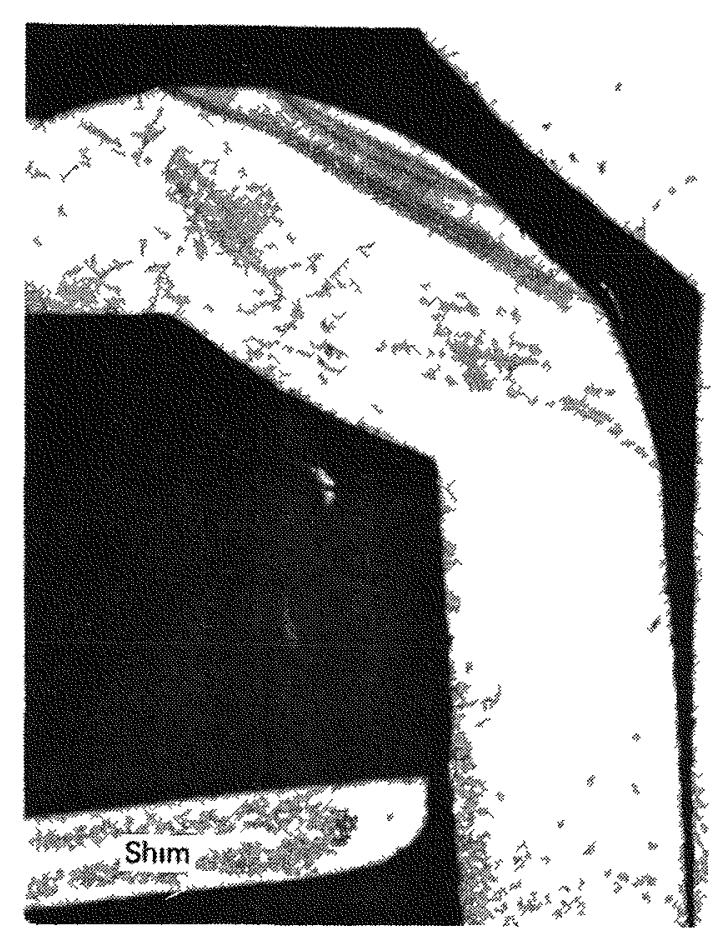

FIGURE 53 - WMT-14 $180^{\circ}$ of impact liner weld 


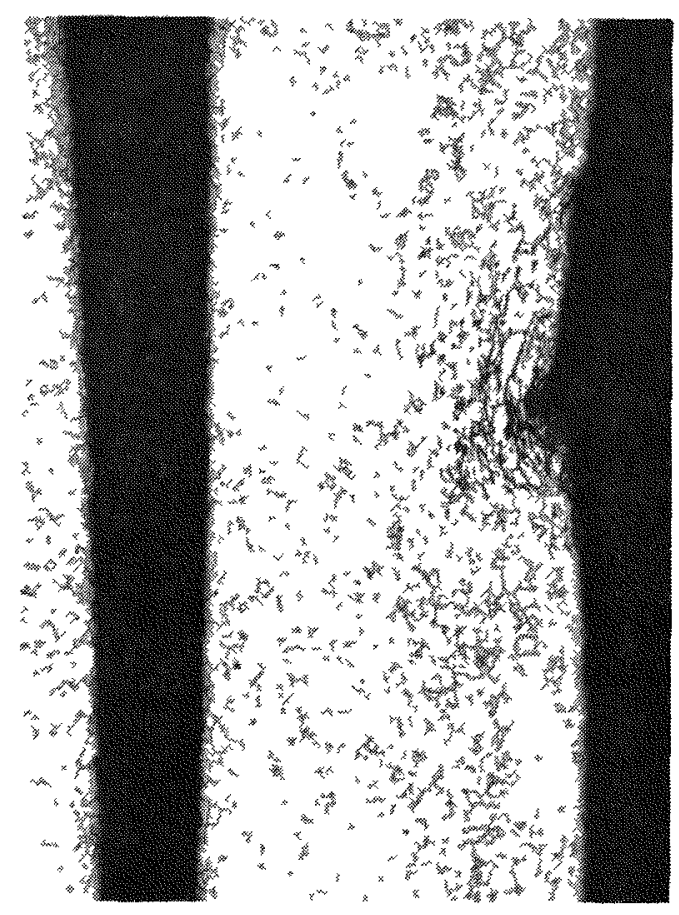

FIGURE 54 - WMT-14 liner side wall showing indentation caused by shim. (100X)

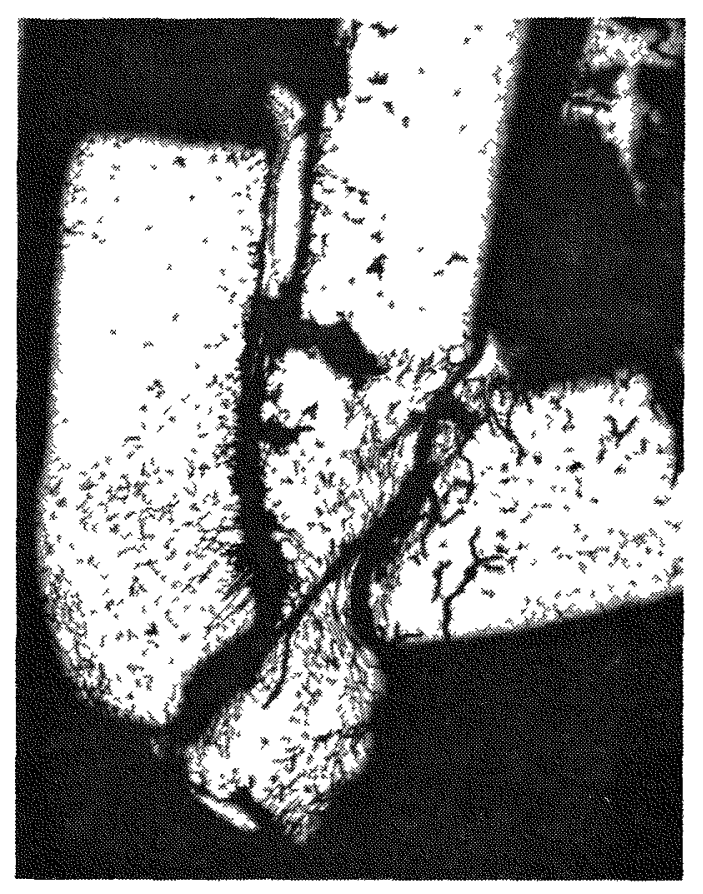

FIGURE 55 - WMT-14 shim at impact face. (100X) 


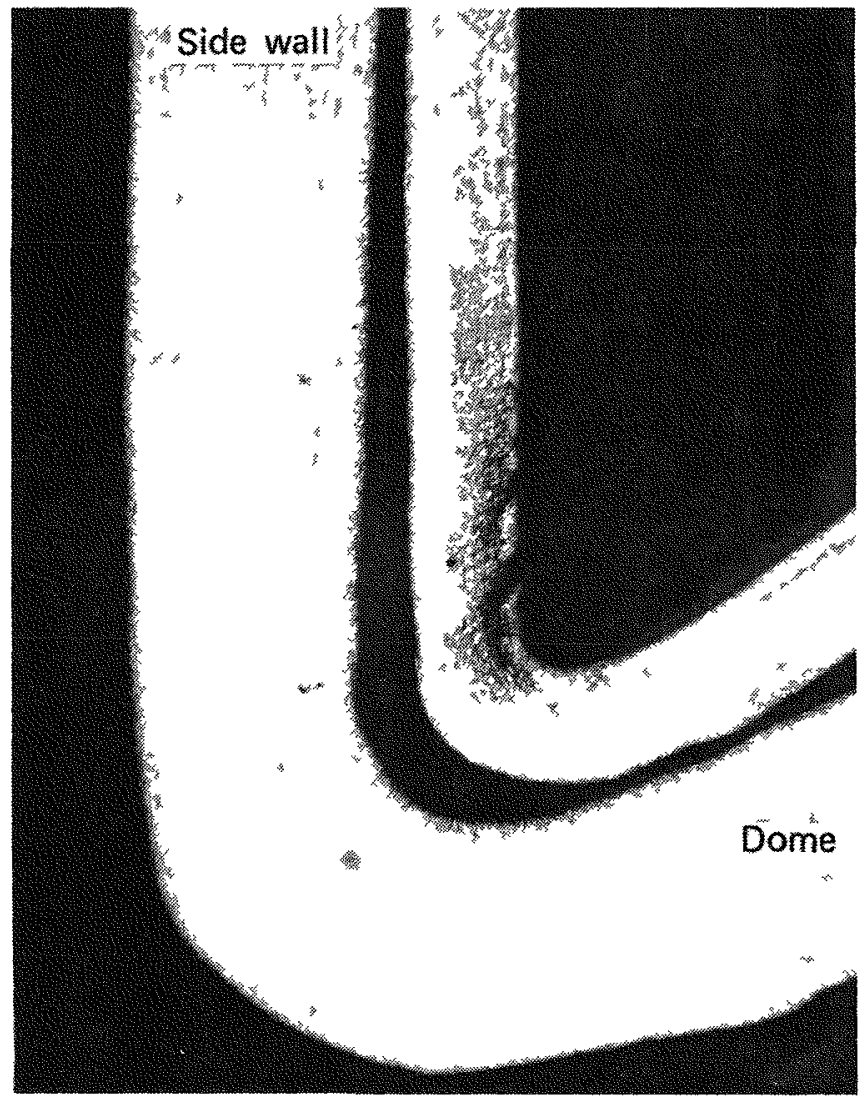

FIGURE 56 - WMT-14 liner and strength member impact face on dome end. (27 5X)

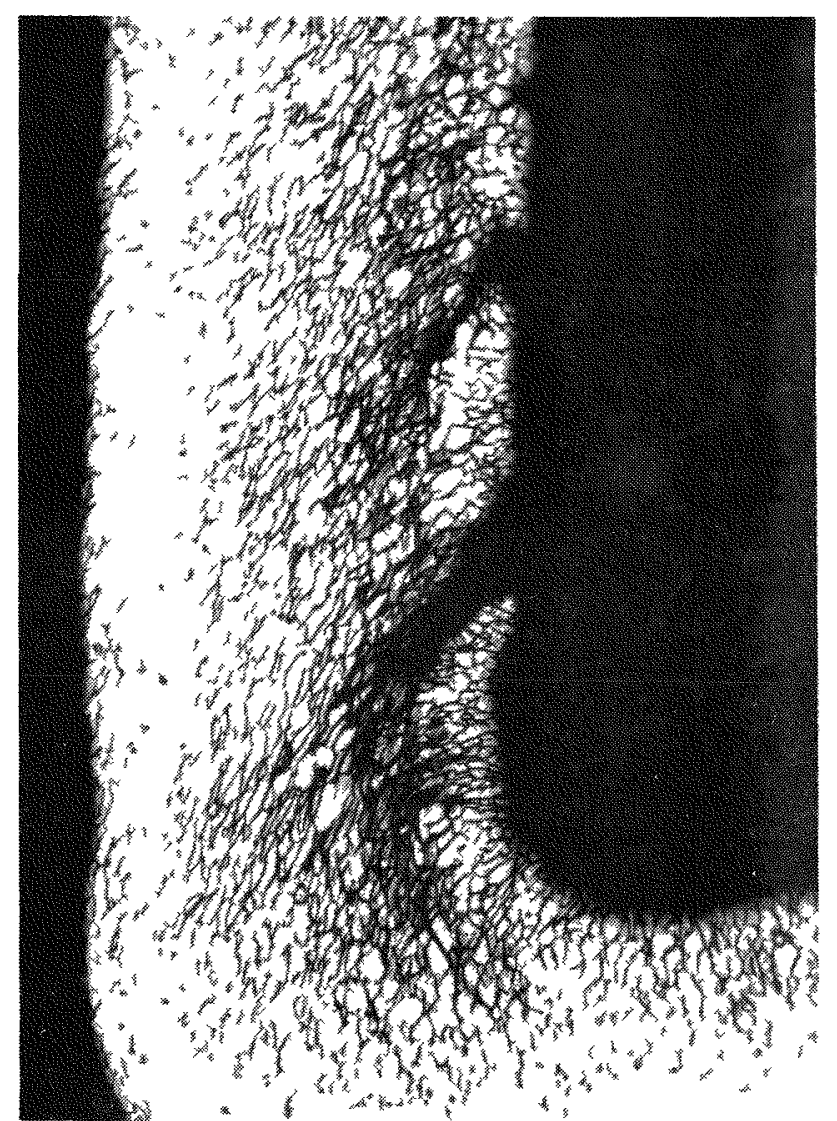

FIGURE 57 - WMT-14 liner impact face dome end. (100X) 


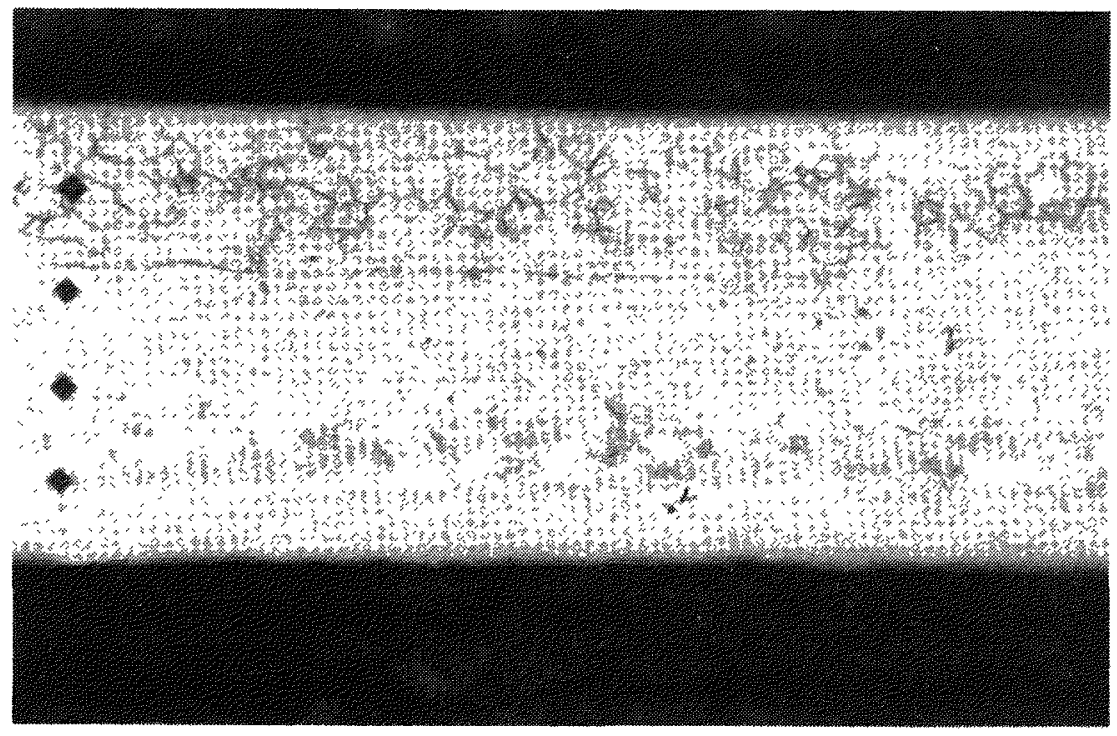

FIGURE 58 - WMT-14 shim. Note variation in grain structure from one side to other side due to embrittlement by oxygen from simulant fuel toward cap. (200X)
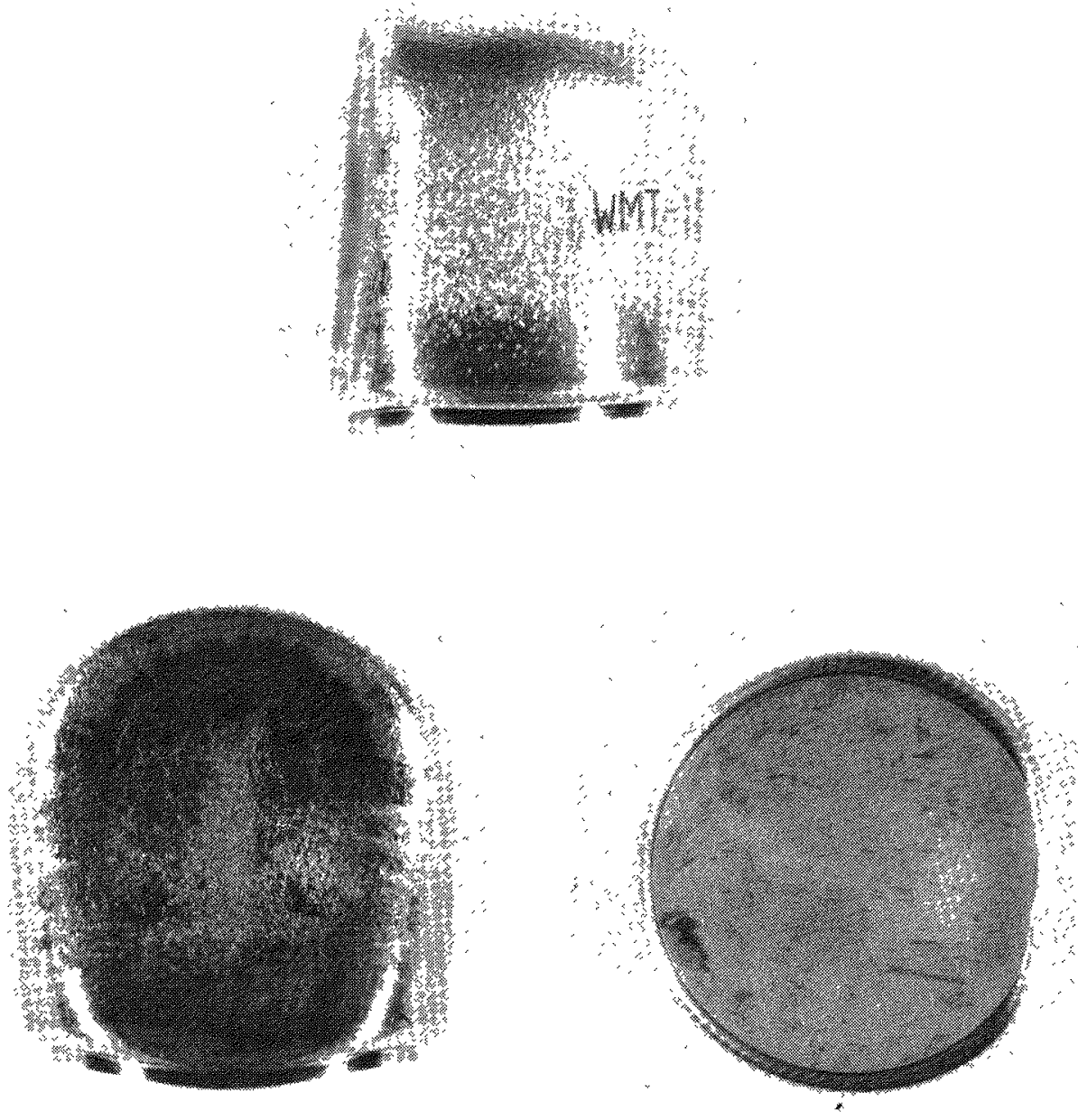

FIGURE 59 - Three views of WMT-15 showing the condition of the clad after side impact at 105.7 $\mathrm{m} / \mathrm{sec}$. Clad was not breached after first impact. 

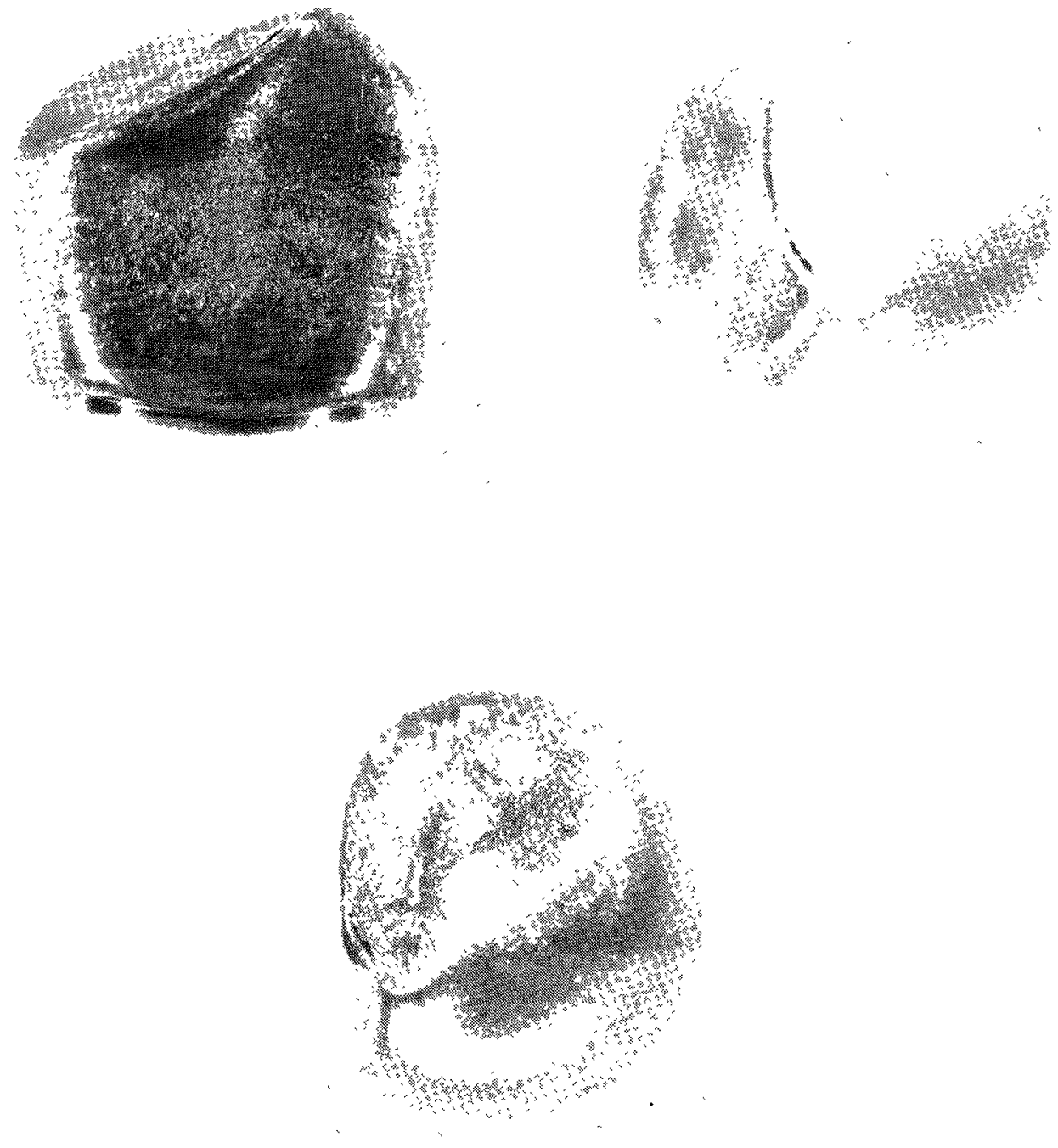

FIGURE 60 - Three views of WMT-15 showing the condition of the clad after the side impact at 105.7 and the dome impact at $104.0 \mathrm{~m} / \mathrm{sec}$. Clad breached in the dome where impact faces overlap. 

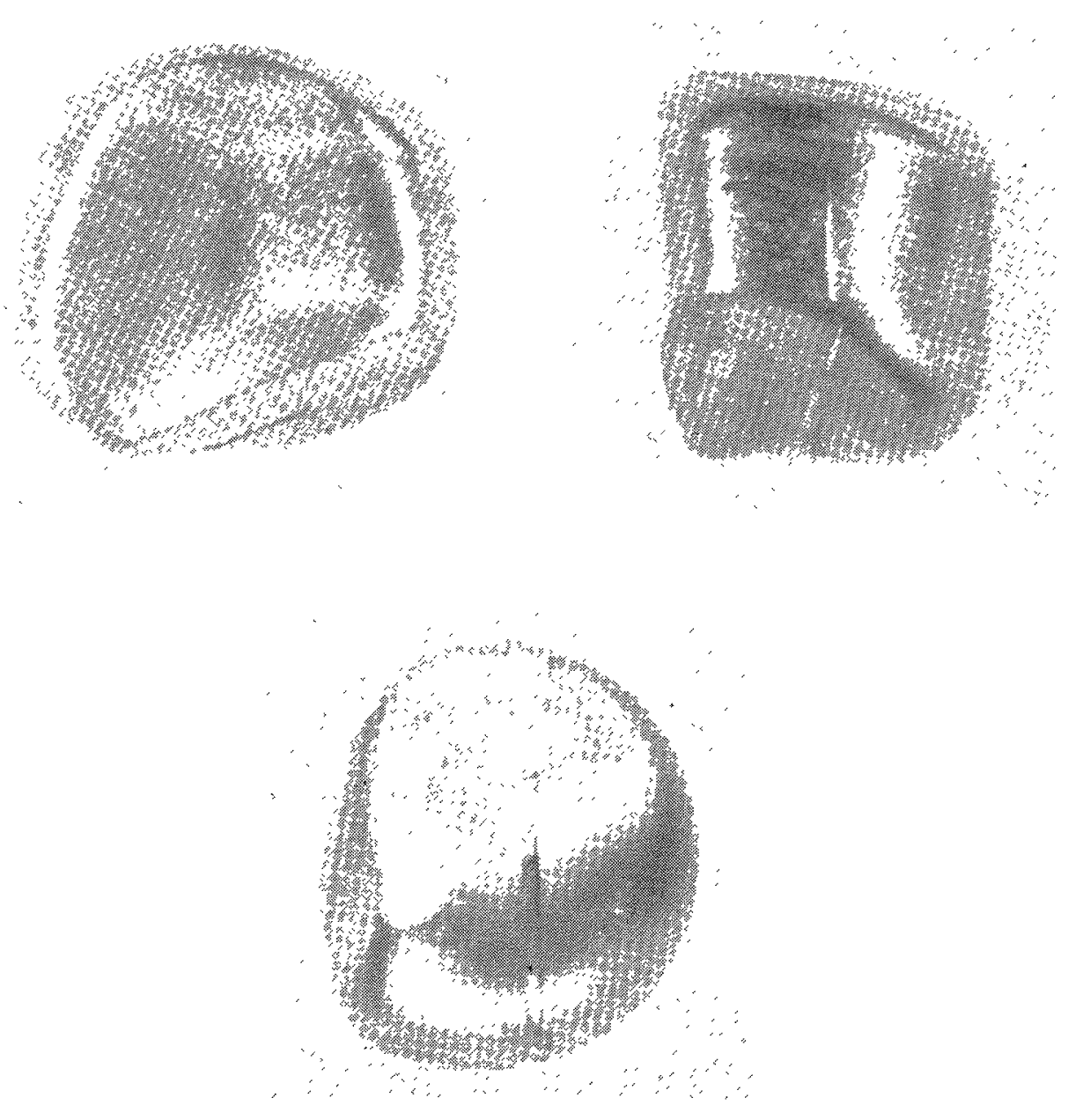

FIGURE 61 - Three views of WMT-15 strength member after double impact. Strength member was not breached.

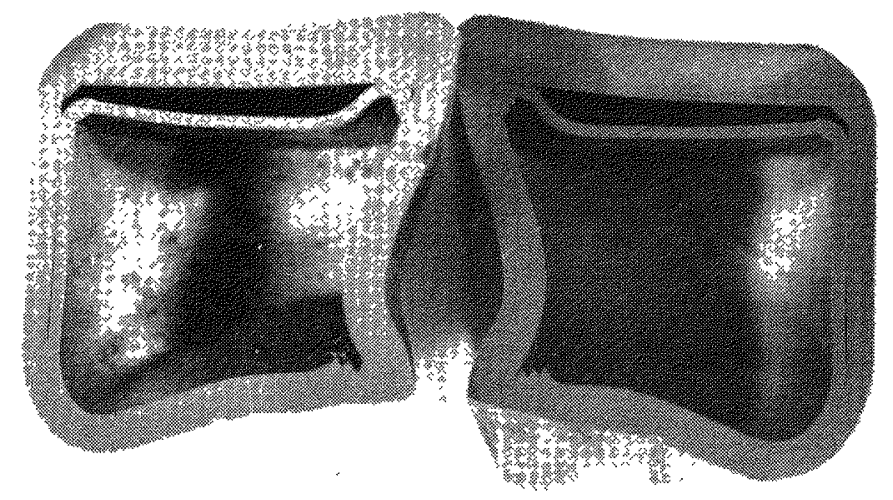

FIGURE 62 - The cross-sectioned strength member and liner of WMT-15 indicated that the liner was severely distorted at the intersection of the impact faces. (See Figure 65) 

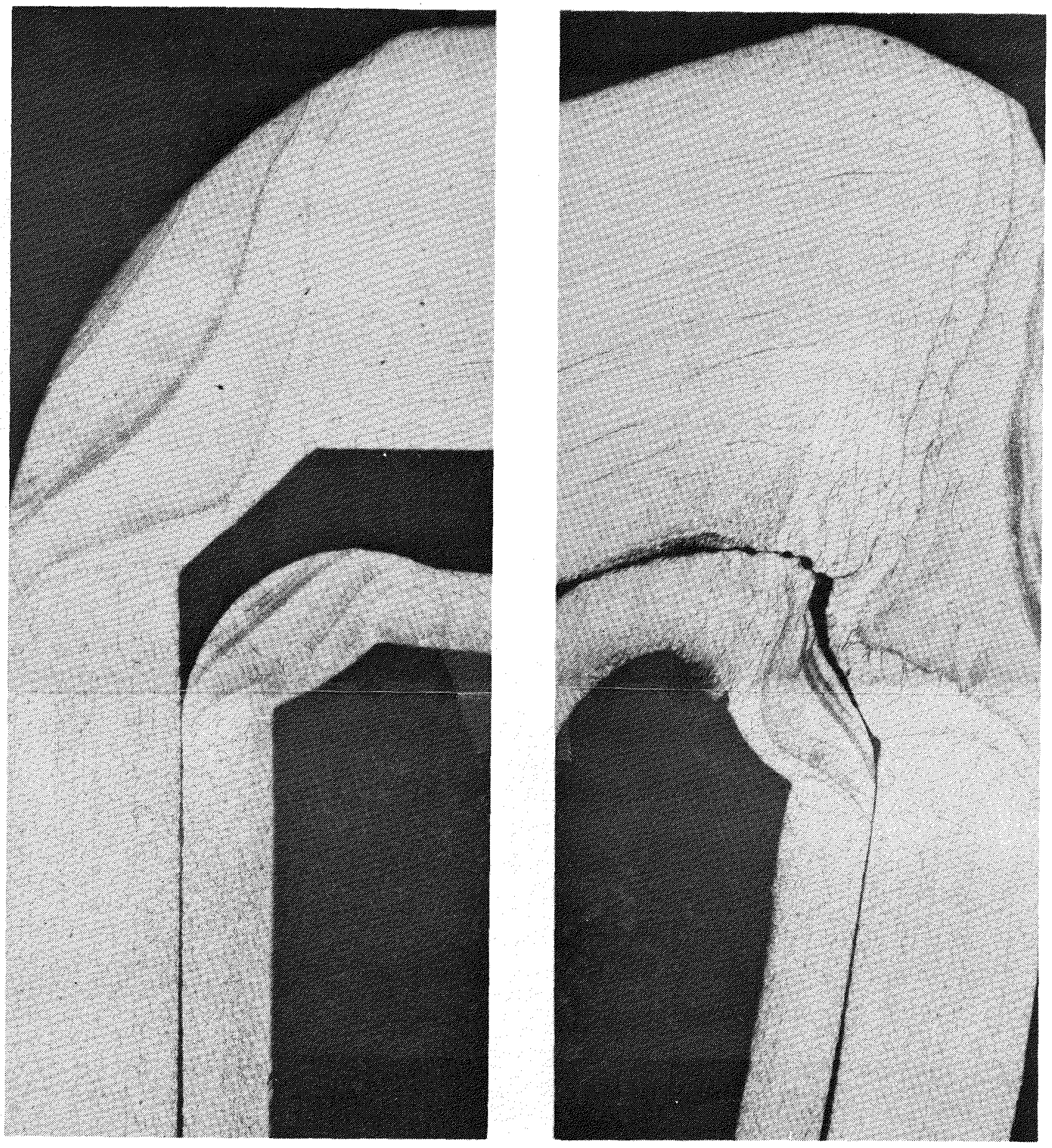

FIGURE 63 - WMT-15 cross section of liner and strength member weld through impact face and $180^{\circ}$ of impact. (27.5X) 

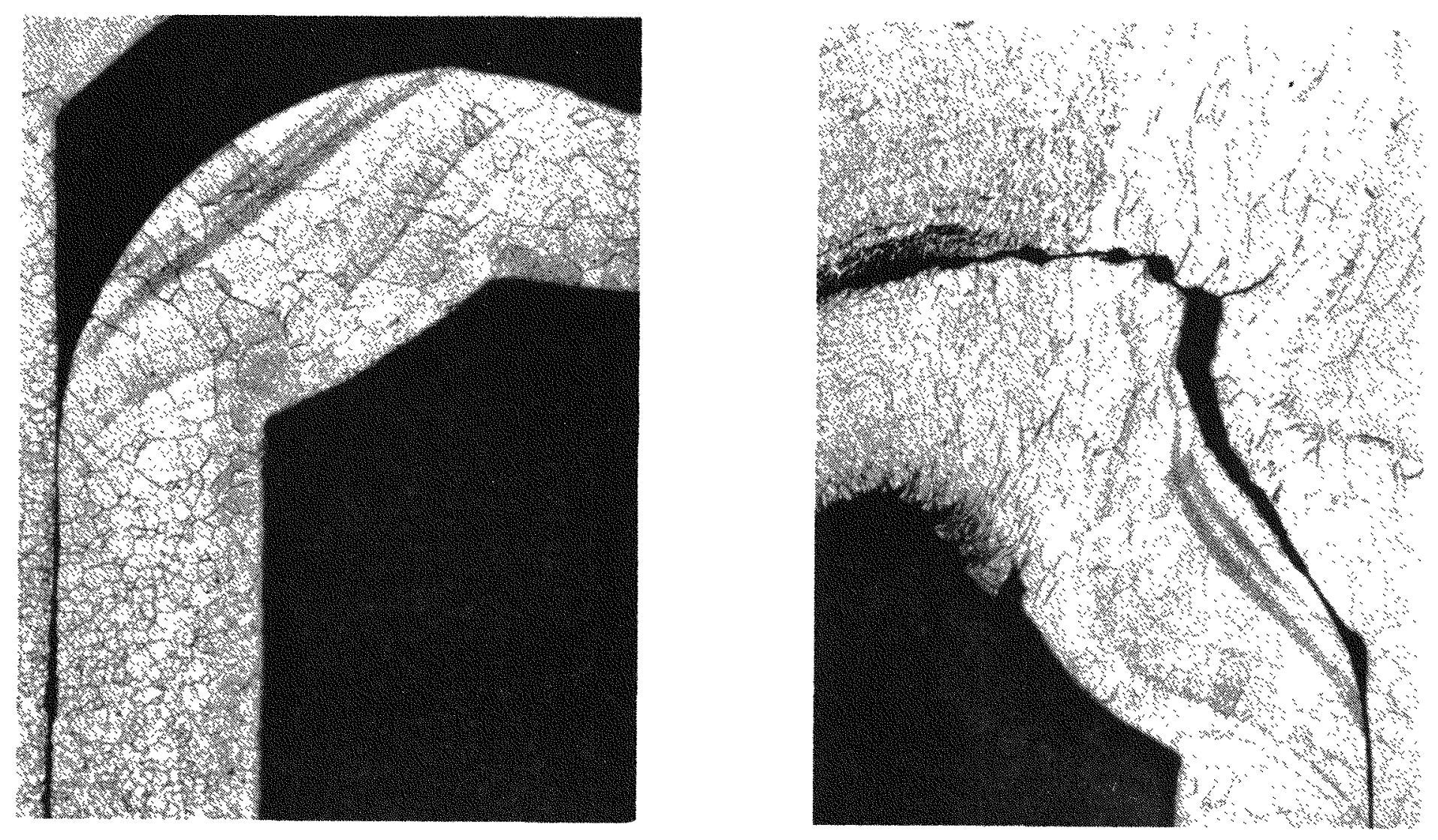


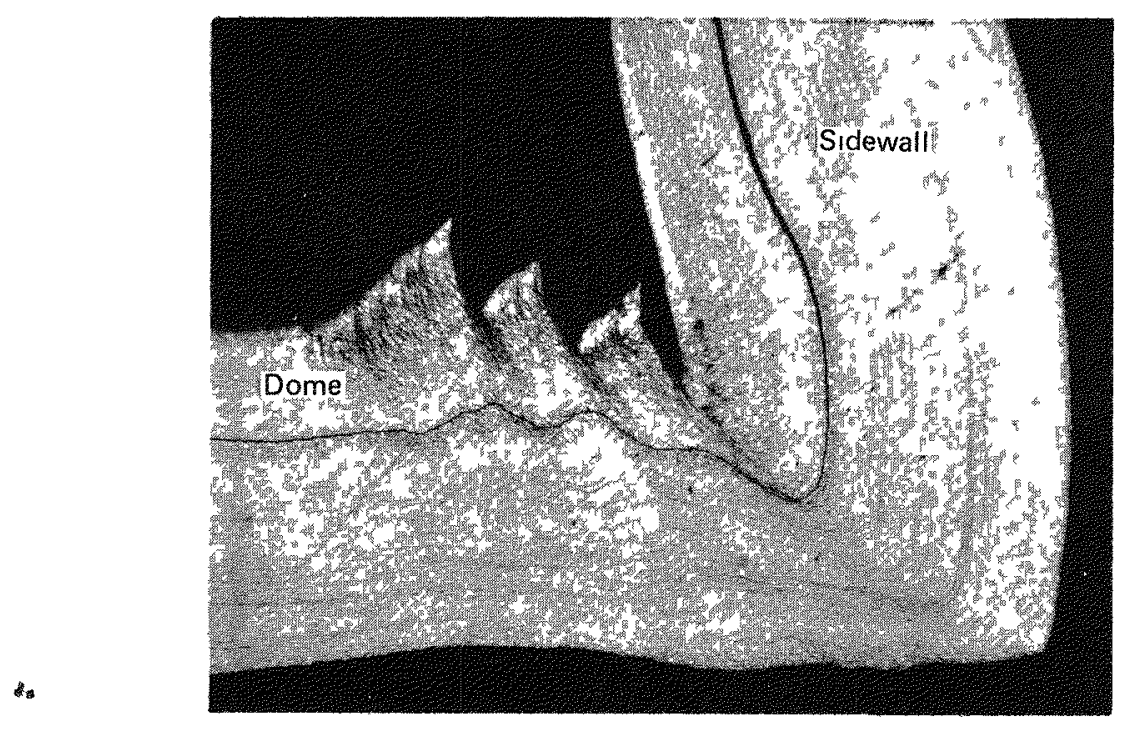

FIGURE 65 - Metallographic examination of the strength member and liner at the intersection of the impact faces indicated that although the liner was severely sheared, it did not breach

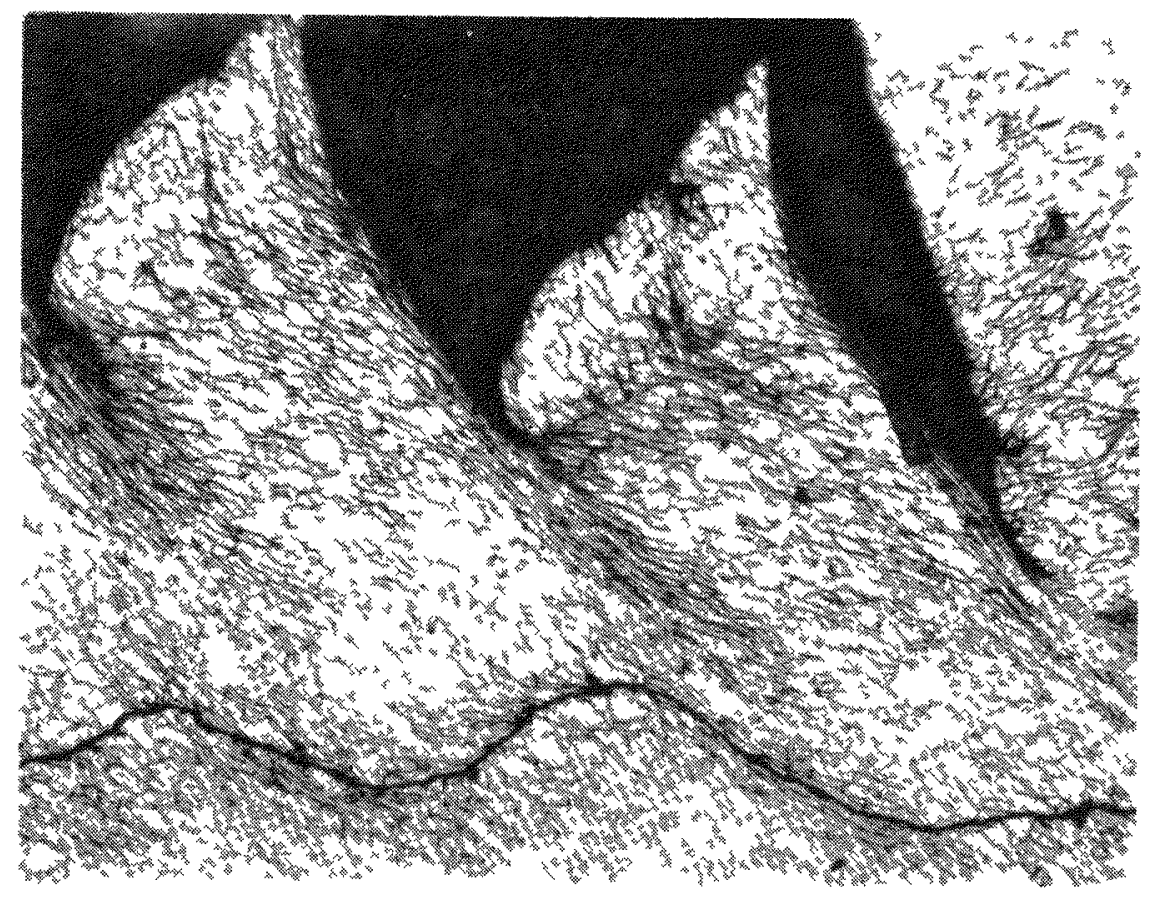

FIGURE 66 - WMT-15 liner, dome end, higher magnification of stressed area (100X) 

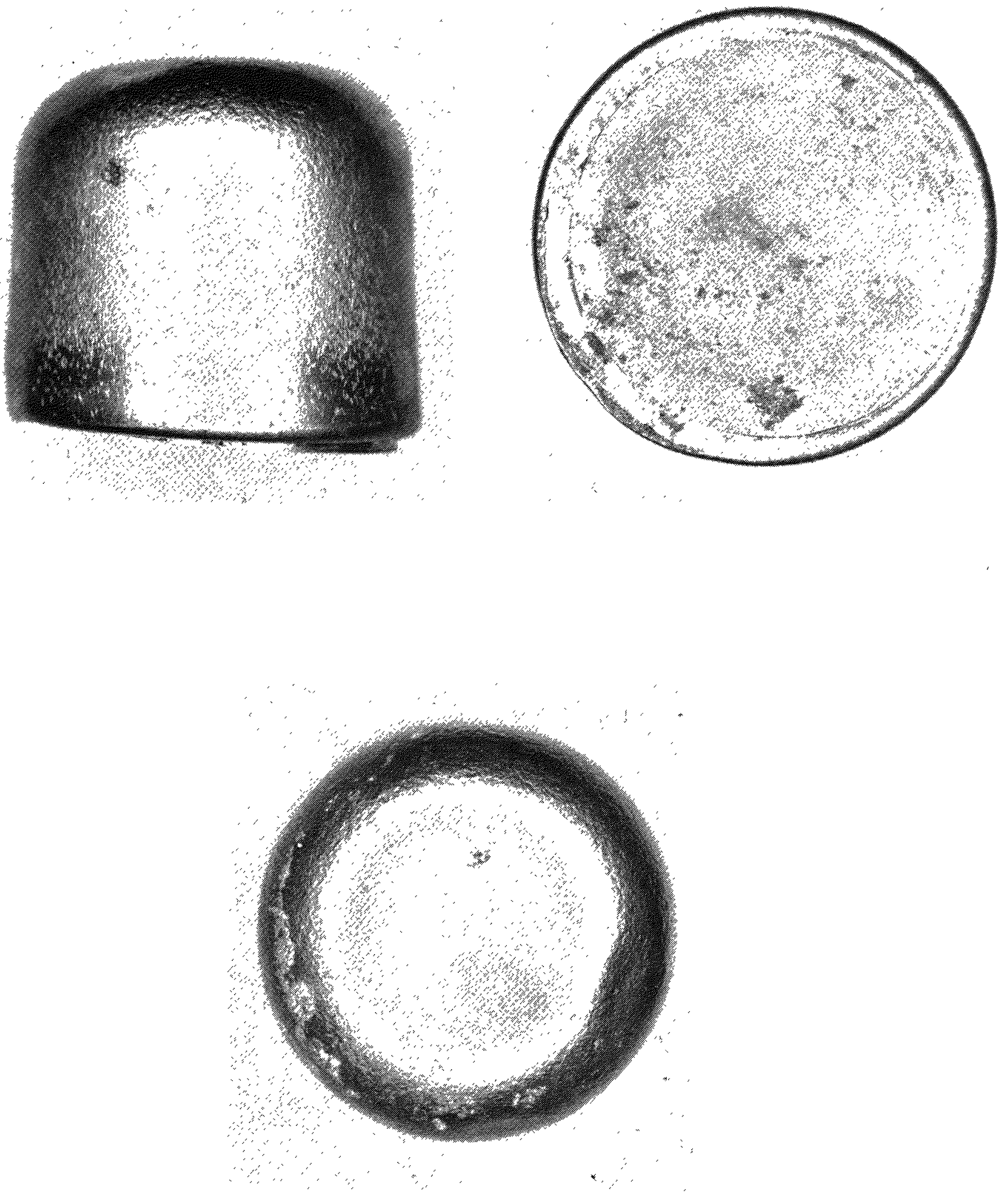

FIGURE 67 - Three views of WMT-17 showing the condition of the clad after first impact at 80.5 $\mathrm{m} / \mathrm{sec}$. The clad was breached in the heat affected zone of the cap to body weld. 

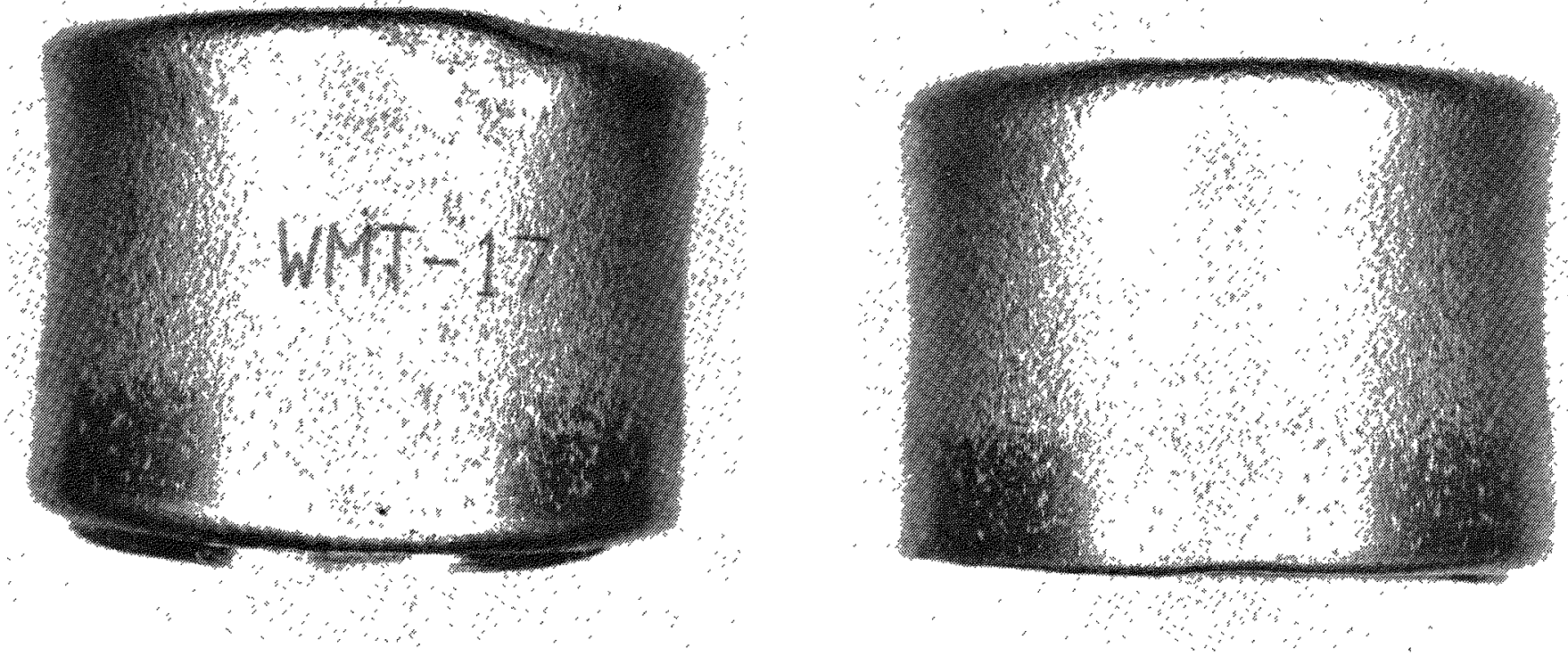

FIGURE 68 - WMT-17 after the cap was impacted at $80.5 \mathrm{~m} / \mathrm{sec}$ and the dome at $80.7 \mathrm{~m} / \mathrm{sec}$.

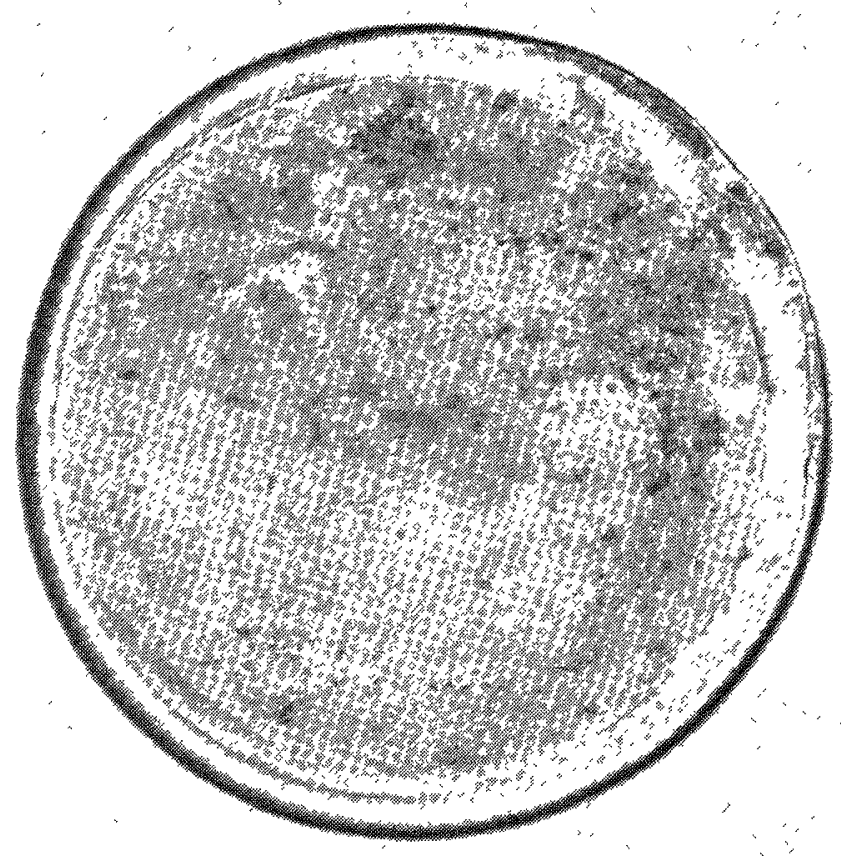

(A)

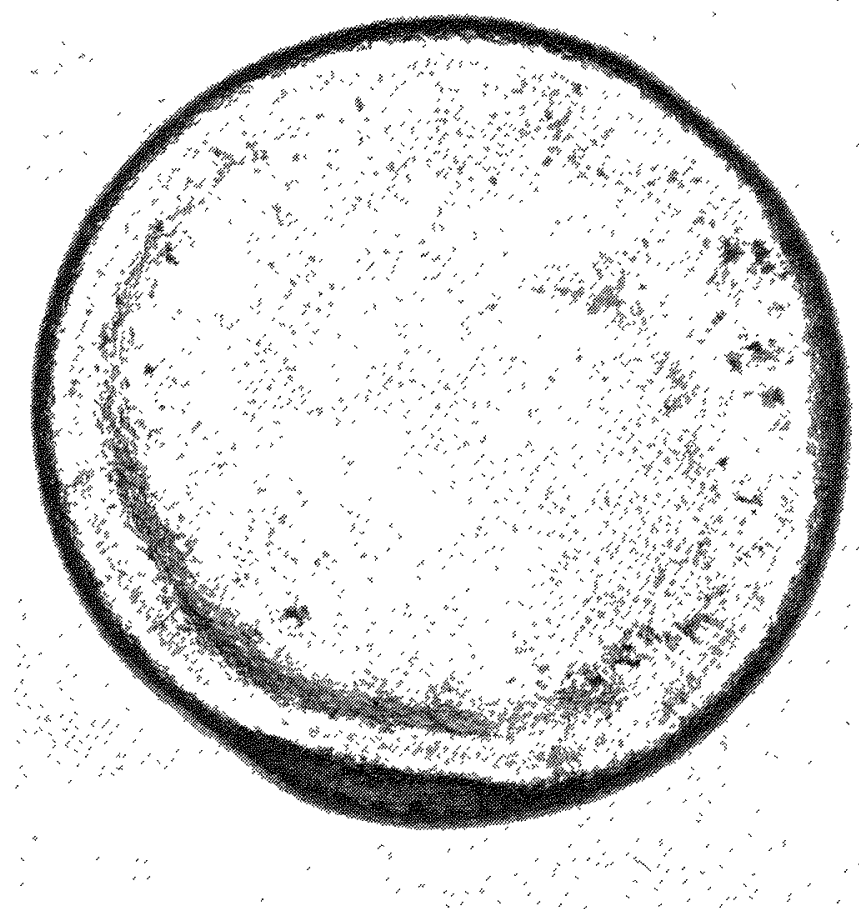

(B)

FIGURE 69 - Showing cap after first impact (A) and dome after second impact (B). Clad was breached in the heat affected zone of the cap to body weld. 


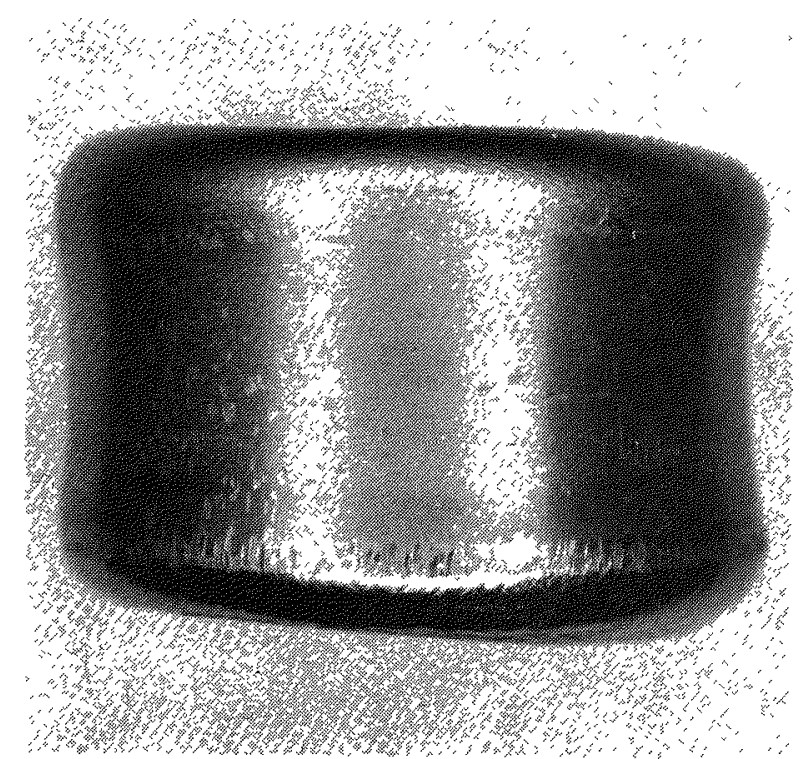

(A)

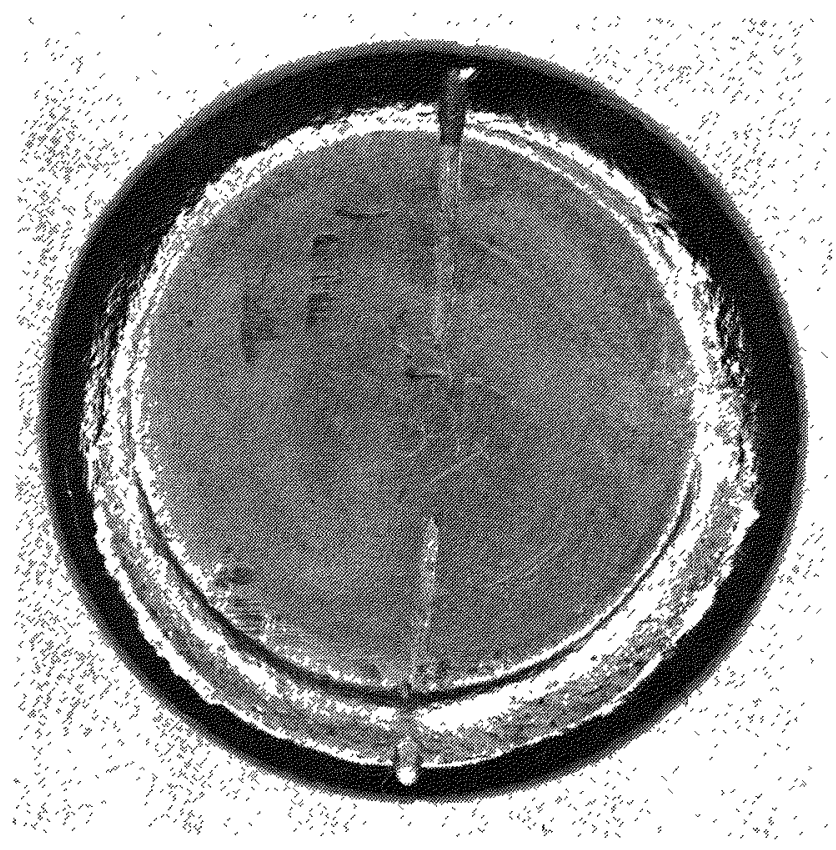

(B)

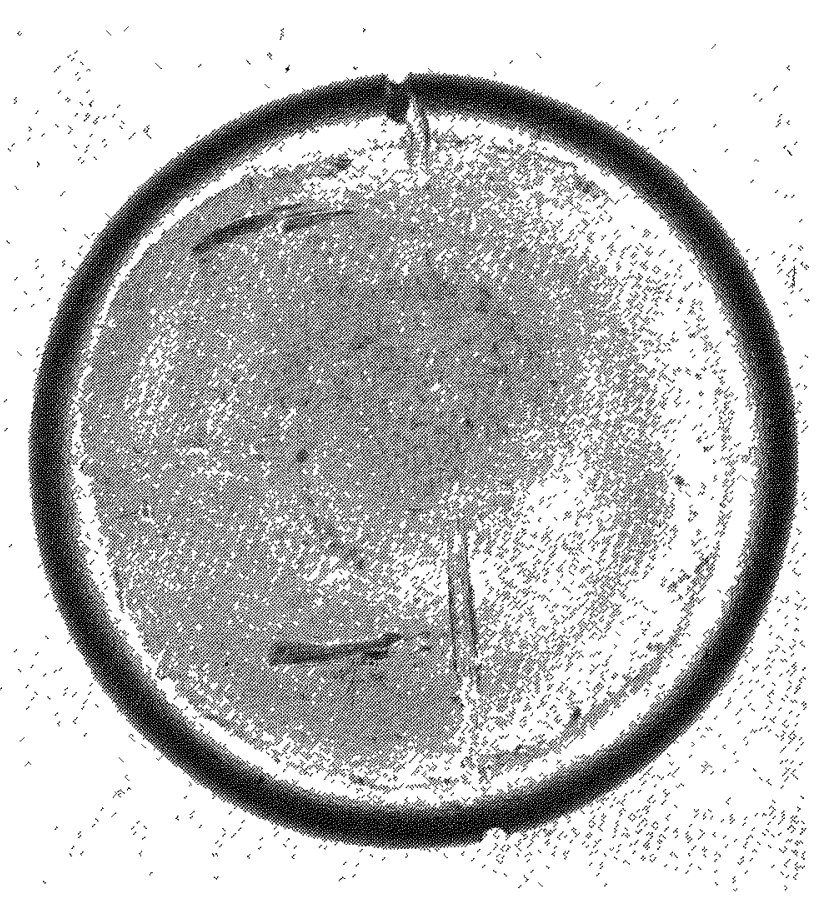

(C)

FIGURE 70 - WMT-17, three views of the strength member after the double impact. The strength member was not breached. Cuts and marks in (B) and (C) occurred during removal of the clad. 

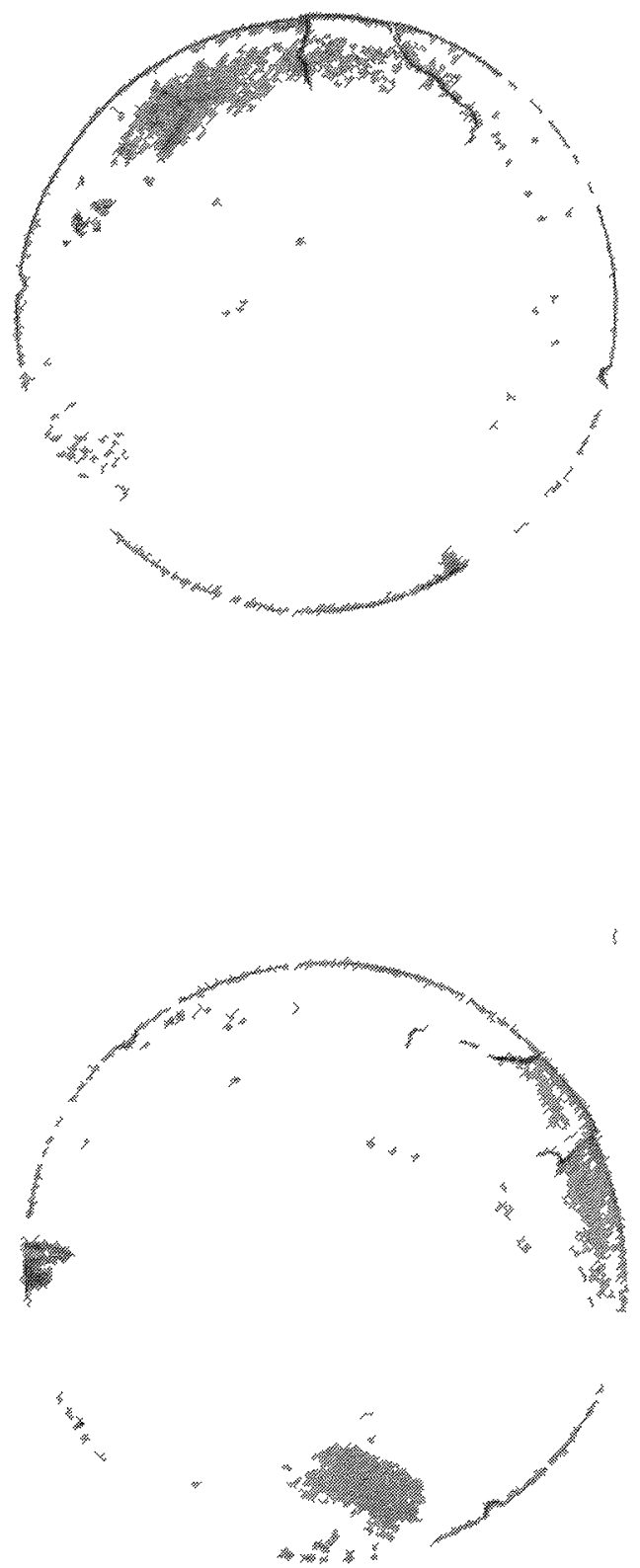

FIGURE 71 - The shım from WMT-17 showed evidence of embrittlement prior to impact 


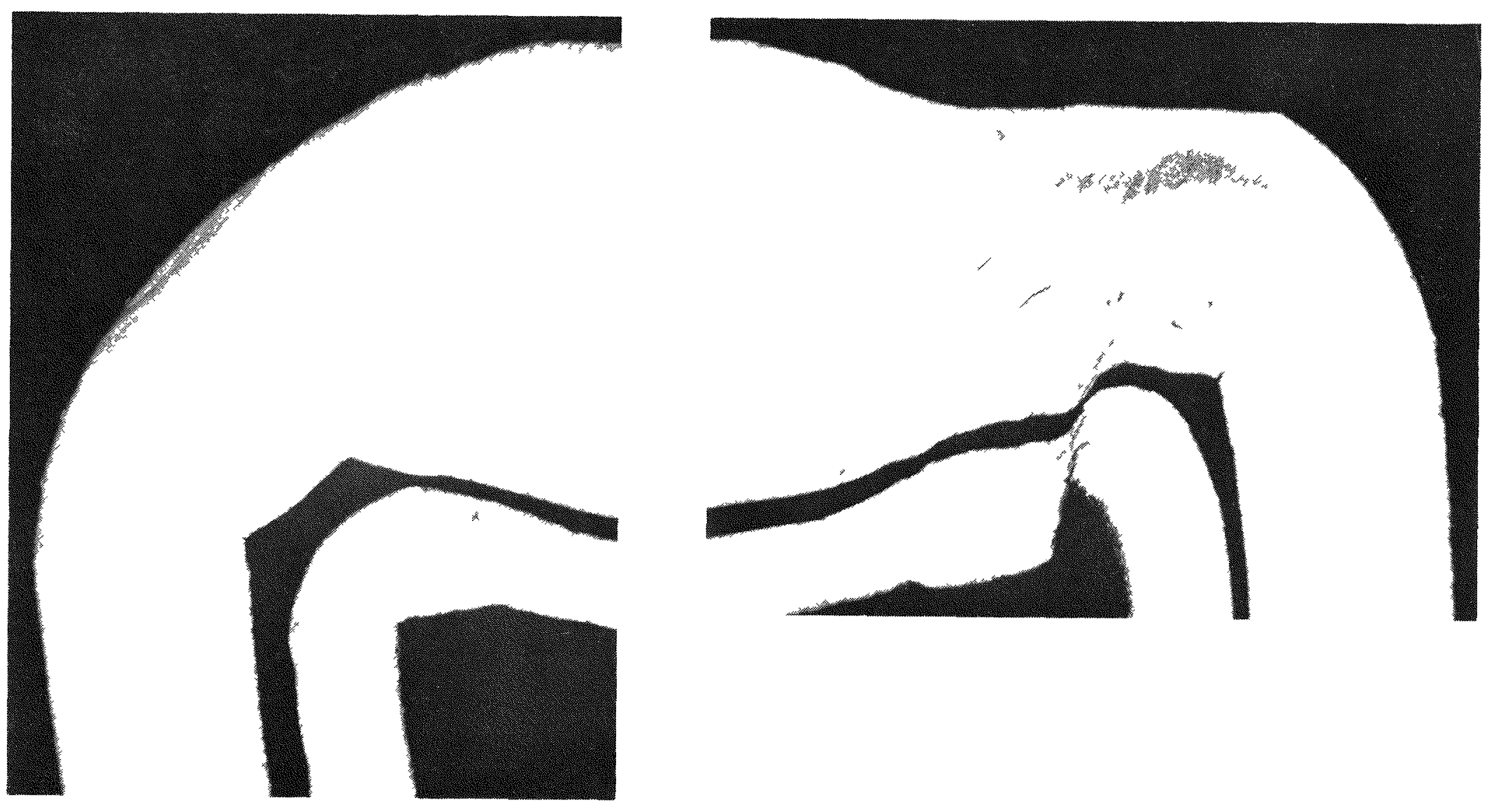



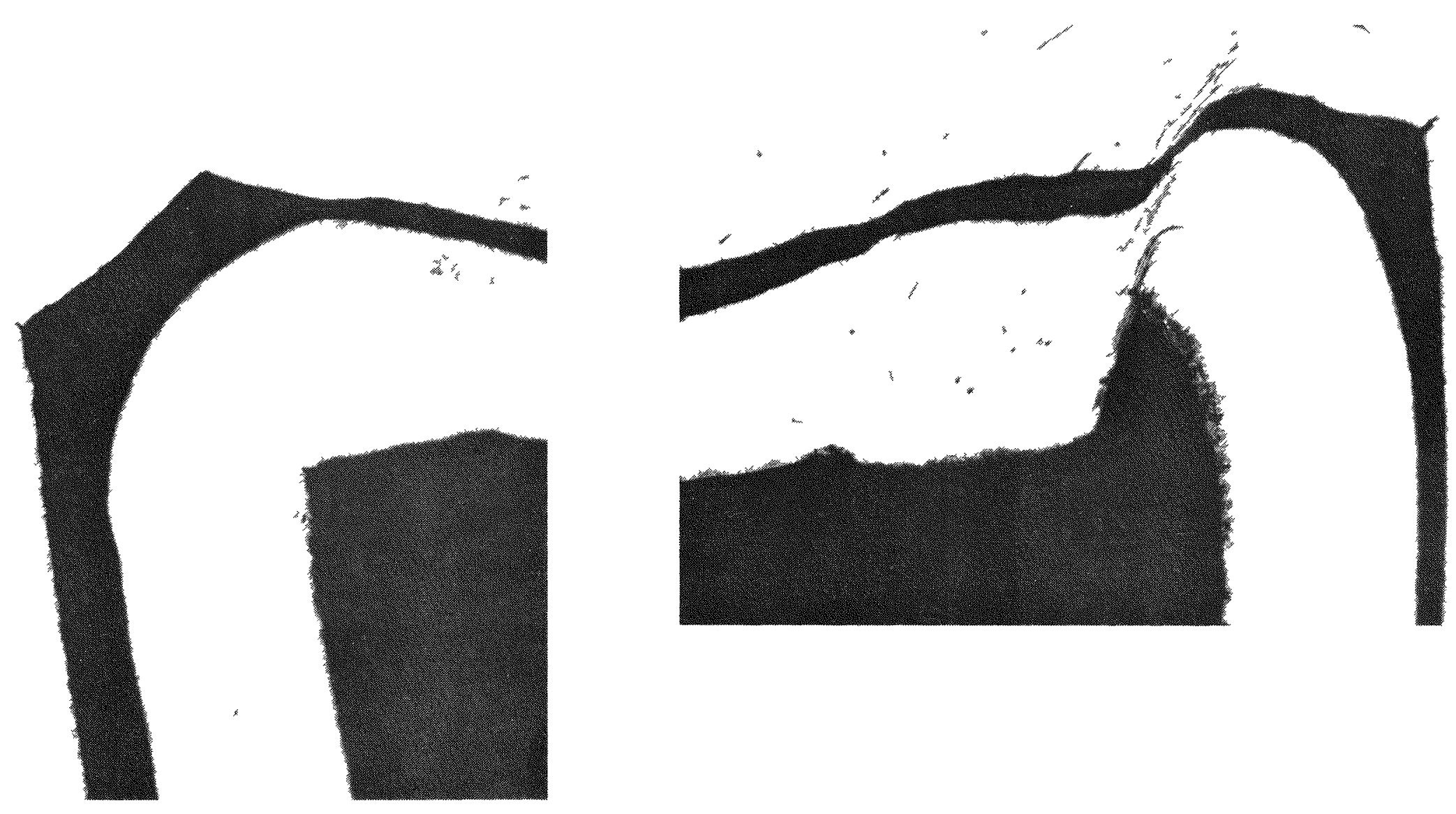

FIGURE 73 WMT 17 cross section of liner weld through impact tace and $180^{\circ}$ of impact at higher maynitication Note shear eftect on liner weld (50X) 

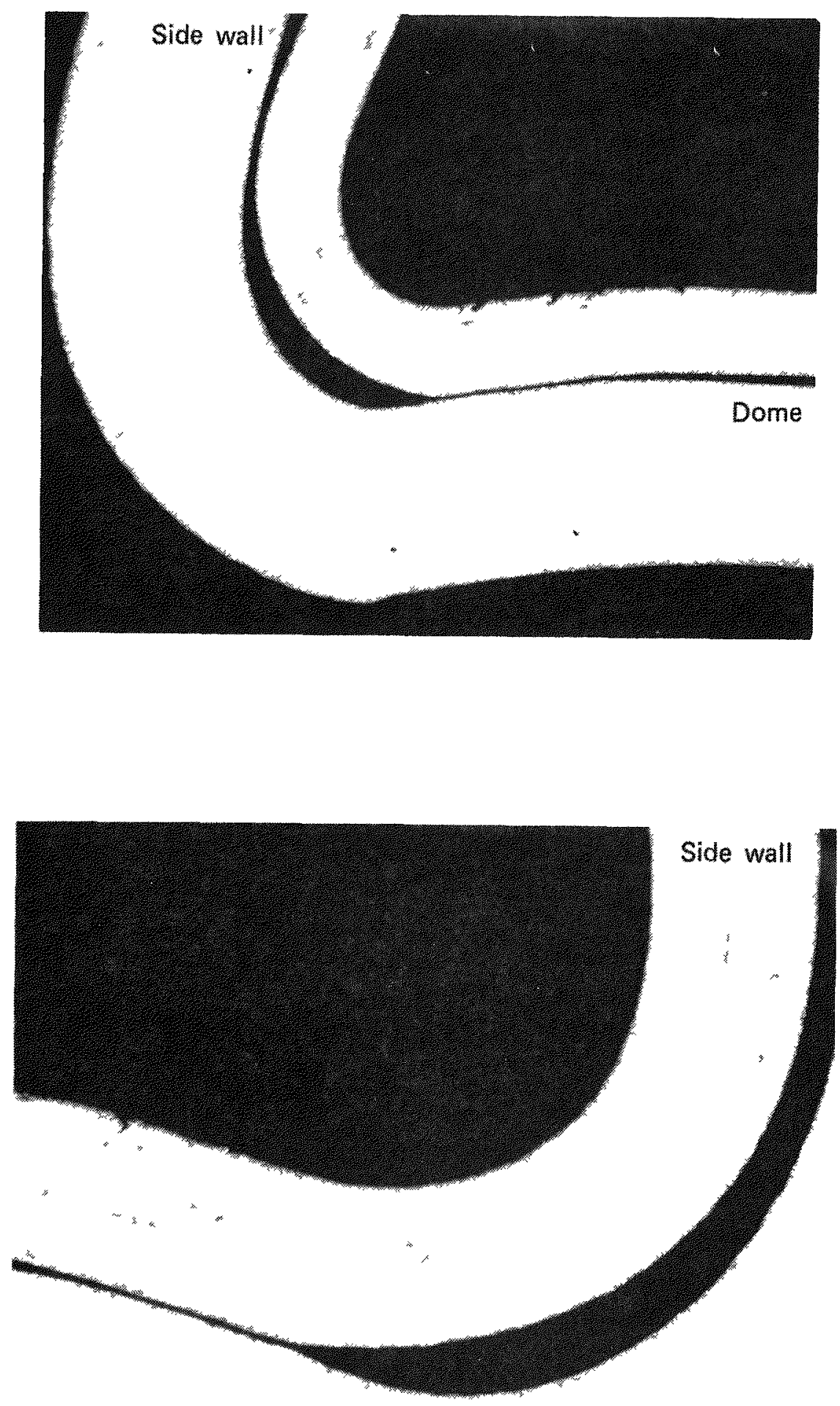

FIGURE 74 WMT 17 cross section of liner and strength member dome end. Note difference in mic ro structure of inside edge of liner and cracks across the dome end. (27 5X) 


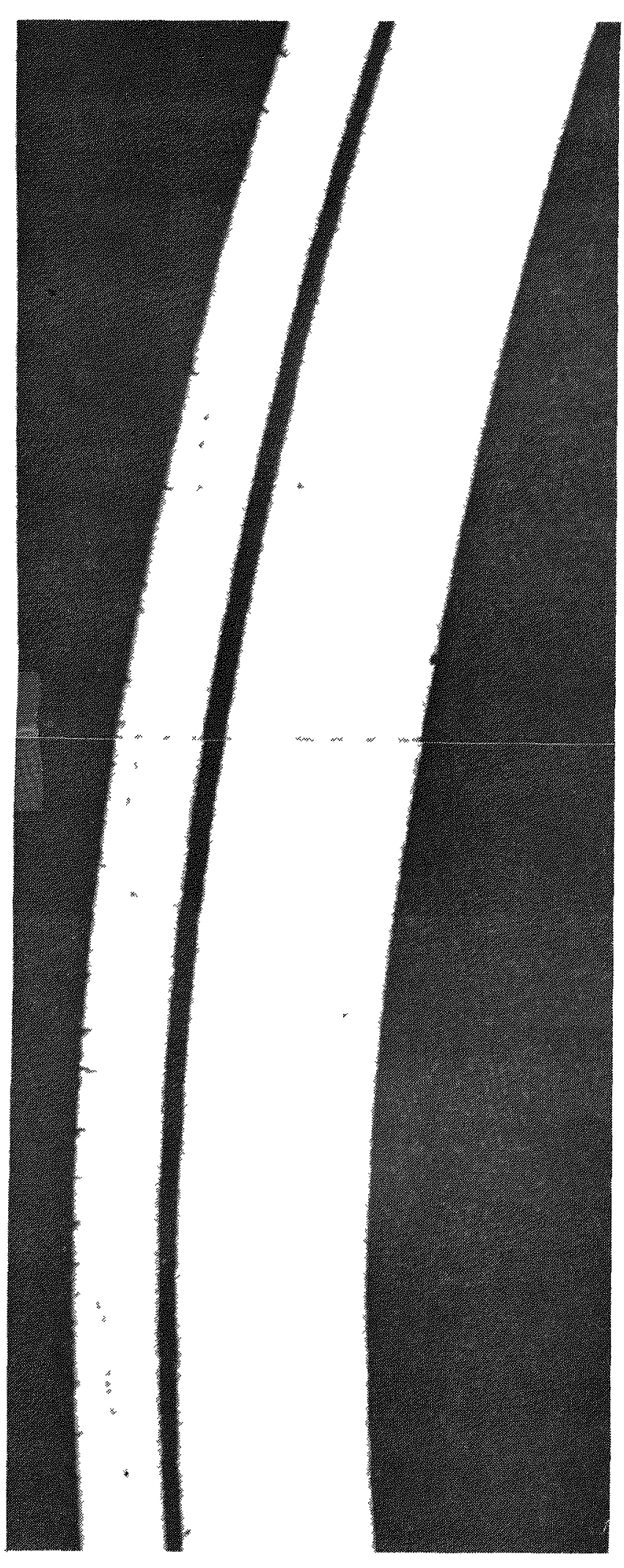

FIGURE 74 contınued 

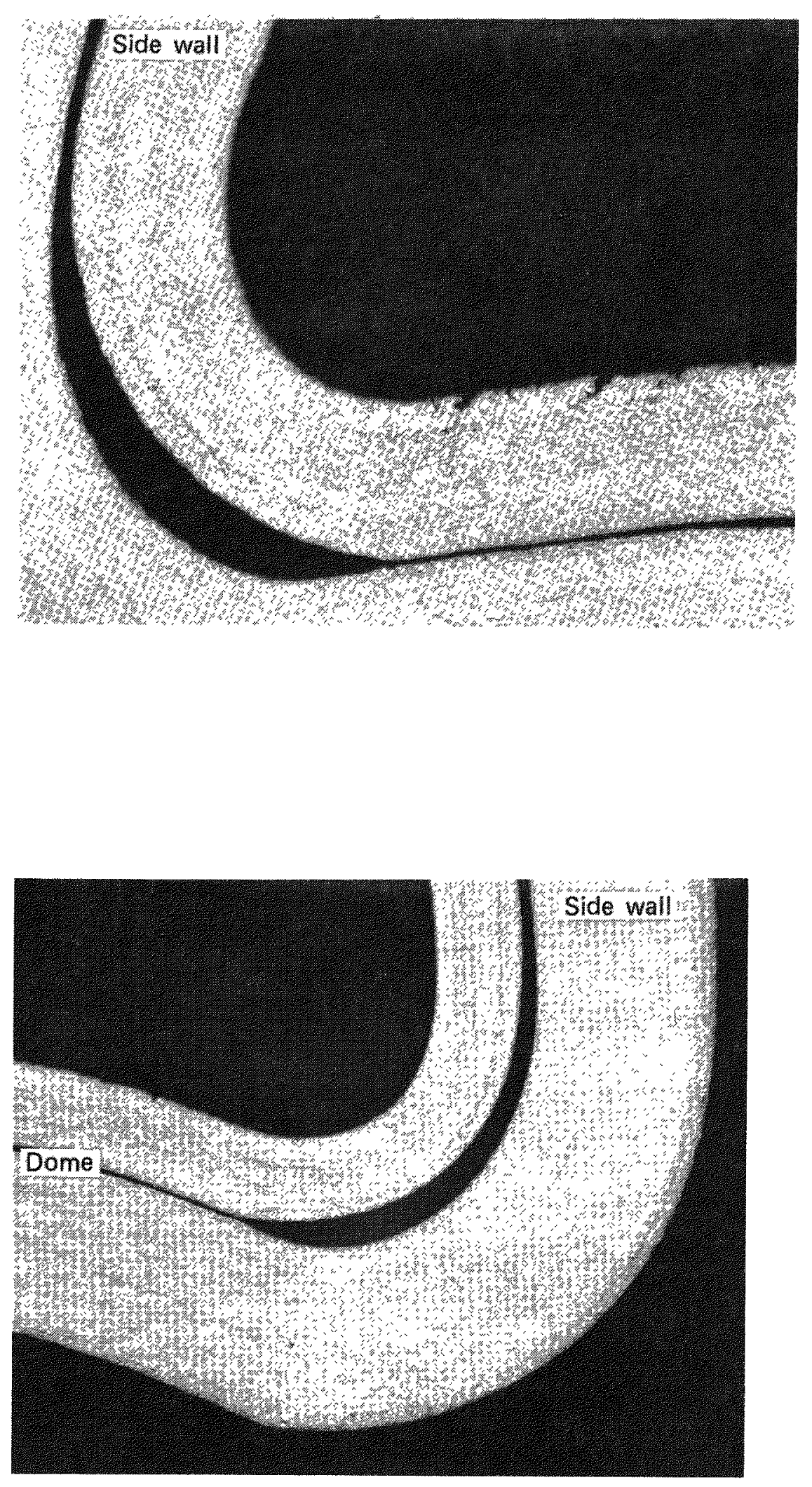

FIGURE 75 - WMT-17 cross section of liner (dome end) at 50X. 


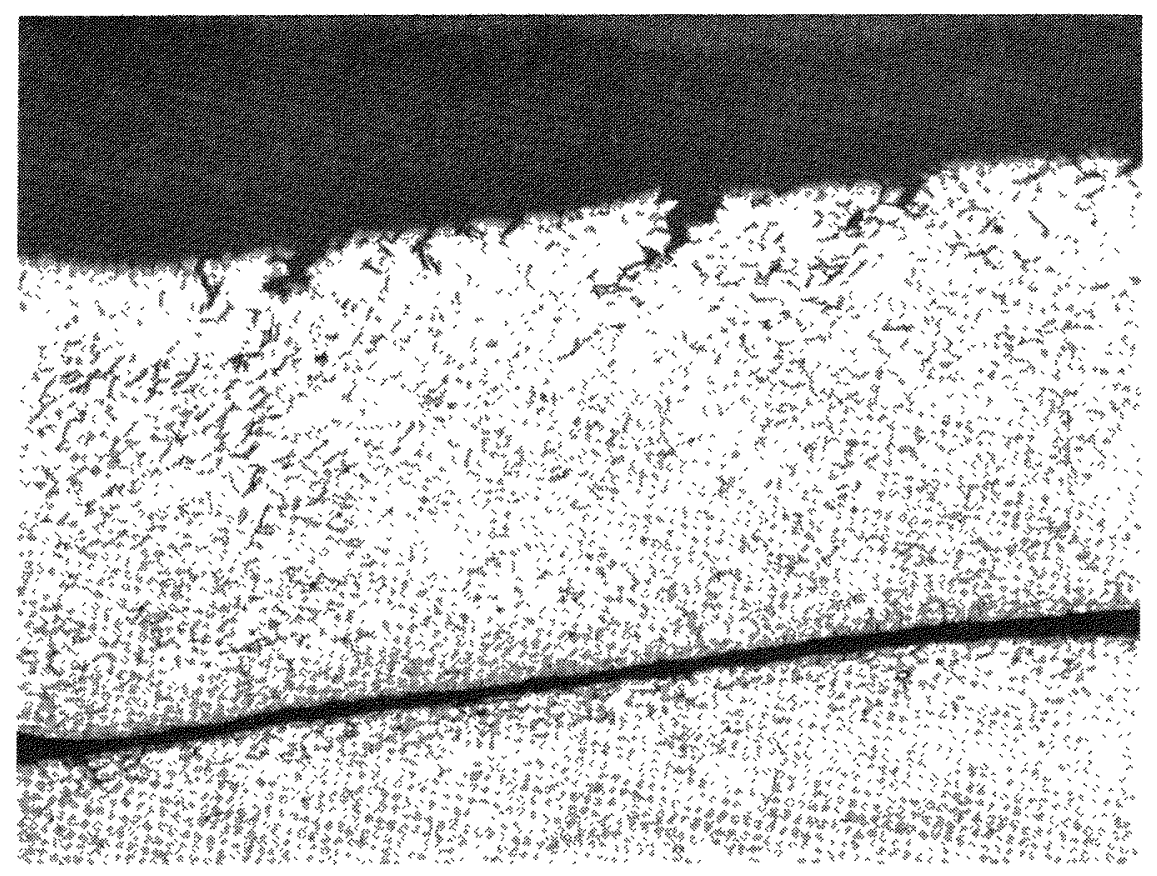

FIGURE 76 - WMT-17 cross section of liner (dome end) at 100X. Micro-structure and cracks indicated that the inside surface of the liner was embrittled. 

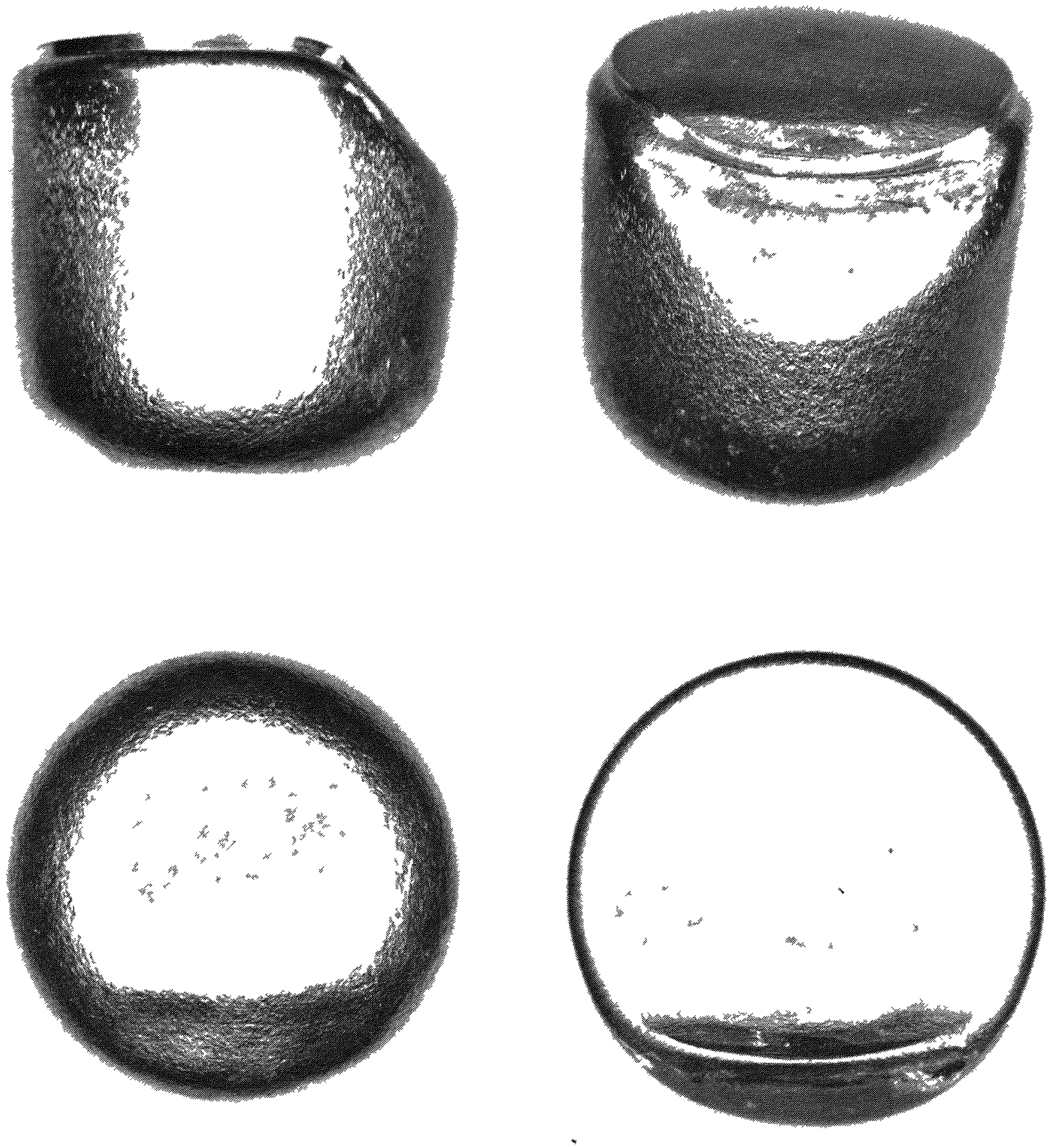

FIGURE 77 Four views of WMYT-05 clad after first impact Clad was not breached 

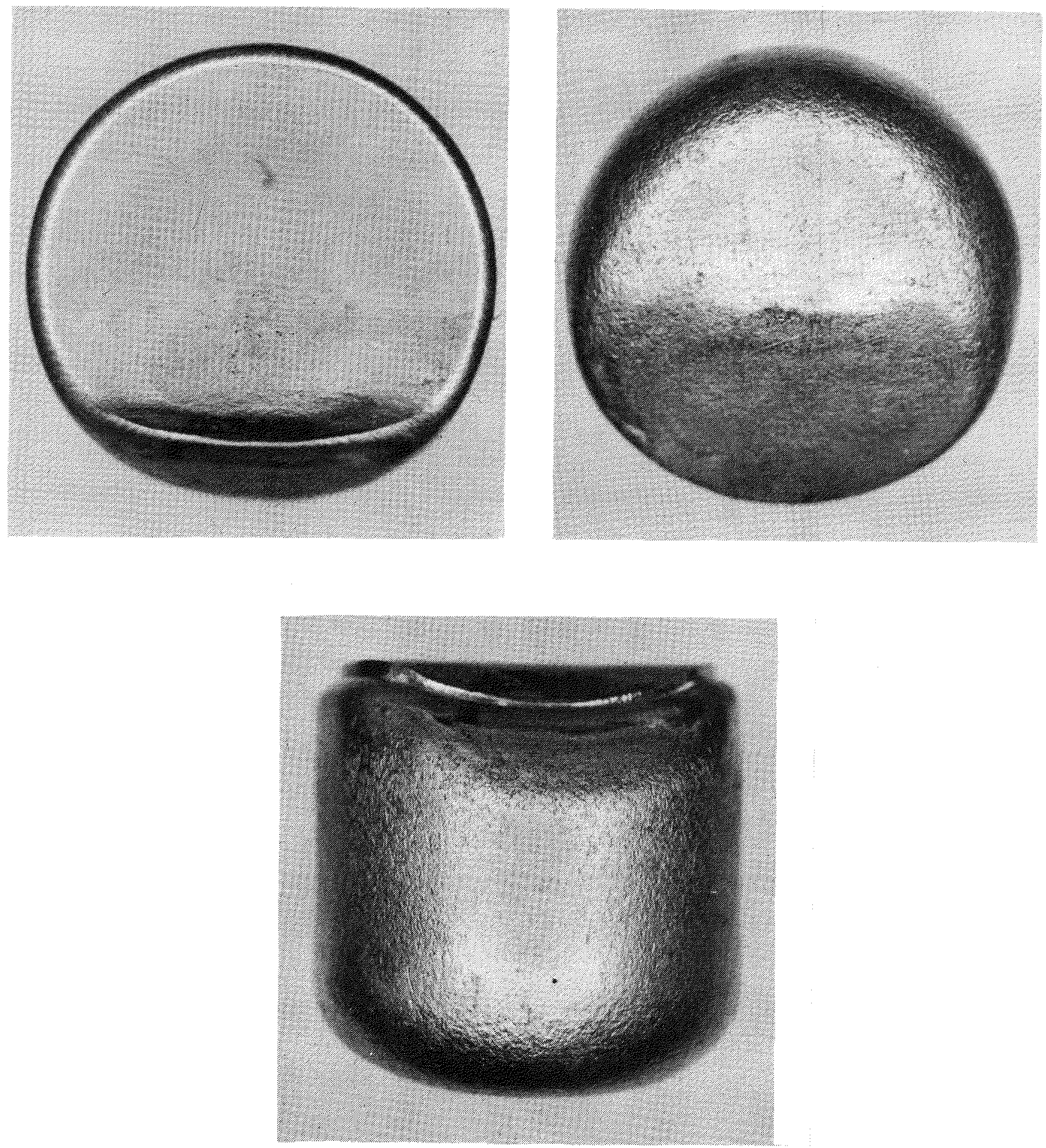

FIGURE 78 - Three views of WMYT-05 after second impact. Clad was not breached. 

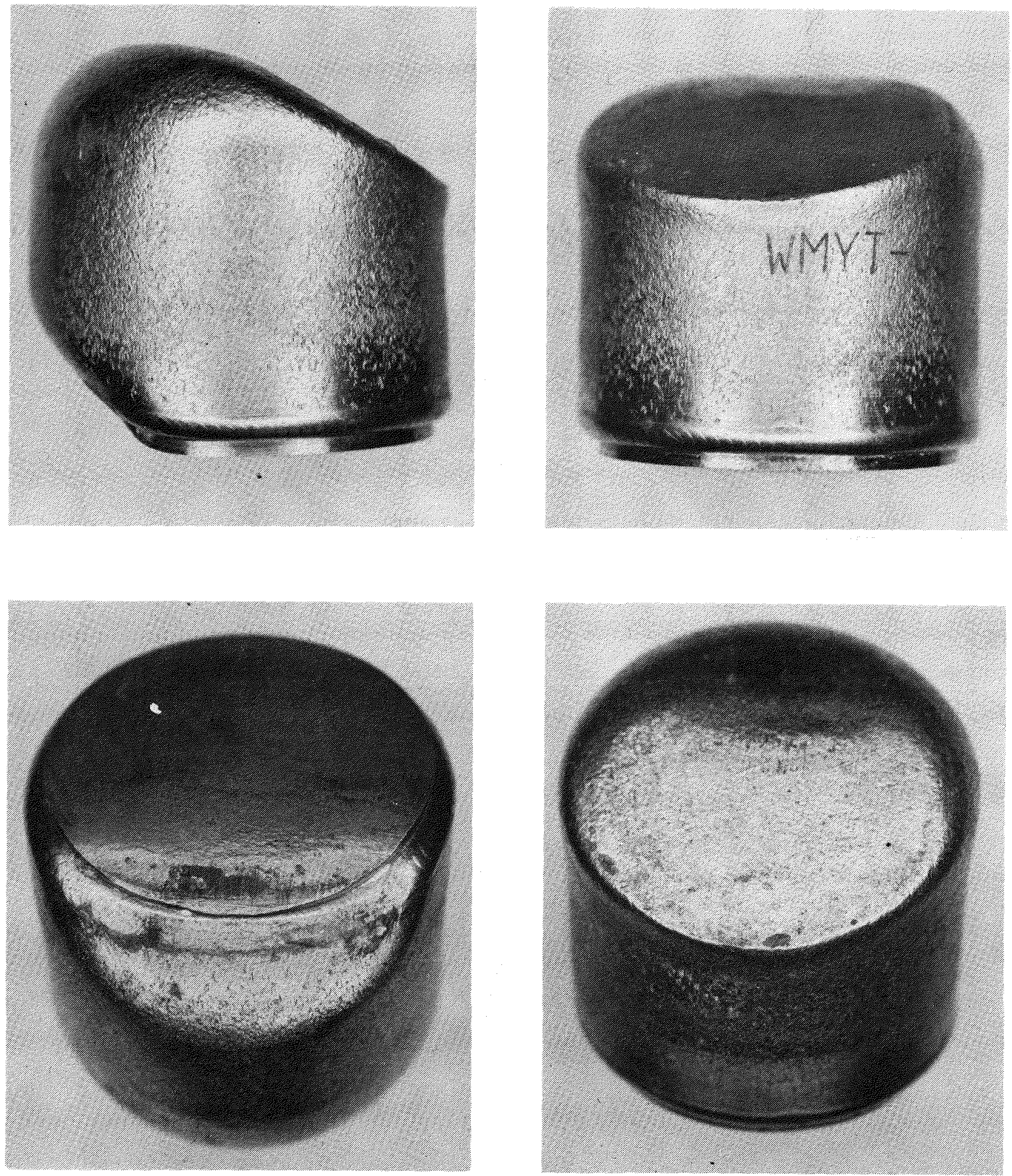

FIGURE 79 - WMYT-05 after the cap corner was impacted at $81.6 \mathrm{~m} / \mathrm{sec}$ and the dome corner at $80.5 \mathrm{~m} / \mathrm{sec}$. 

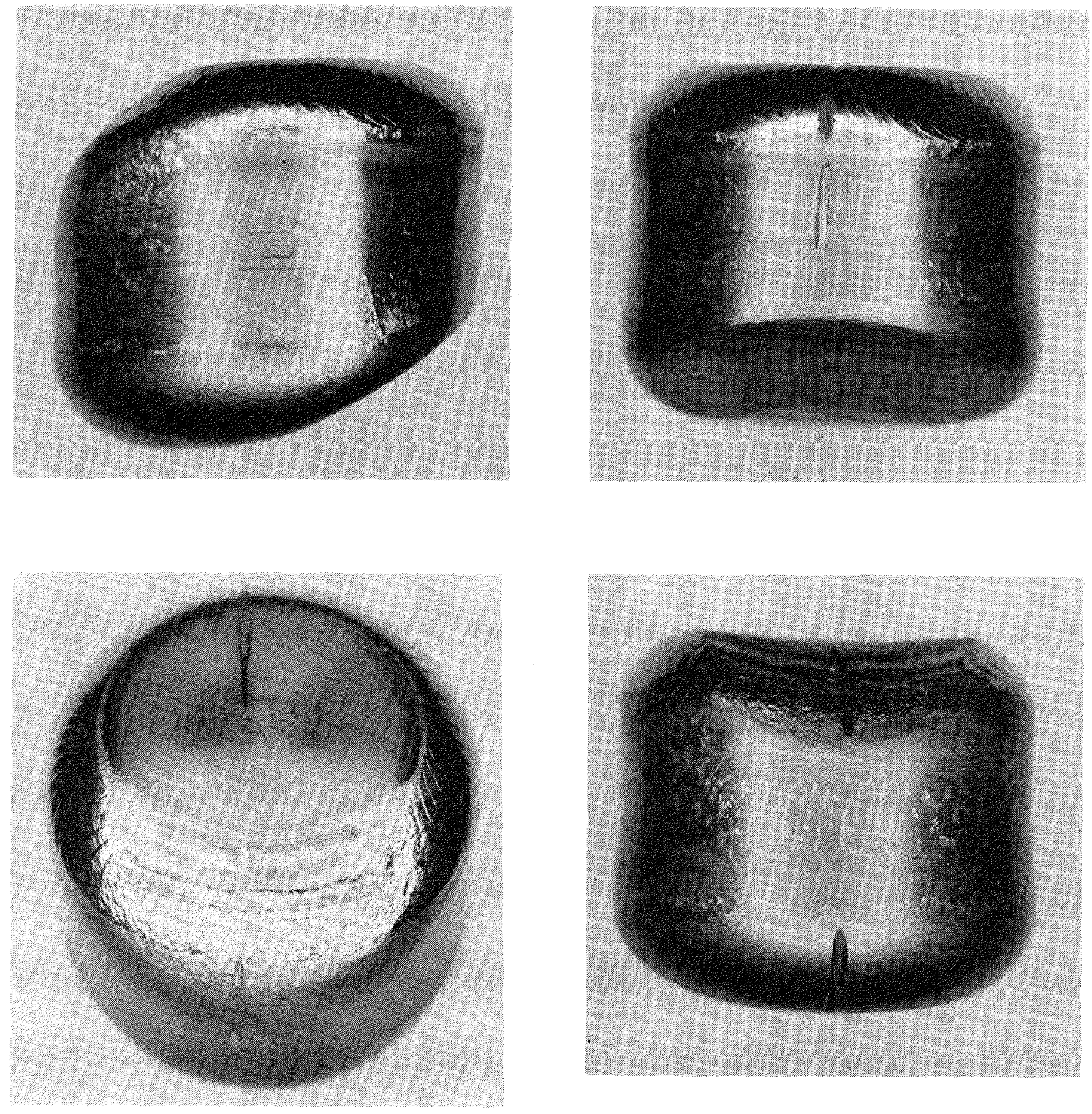

FIGURE 80 - Five views of WMYT-05 strength member. Both liner and strength member emerged in relatively good condition. 


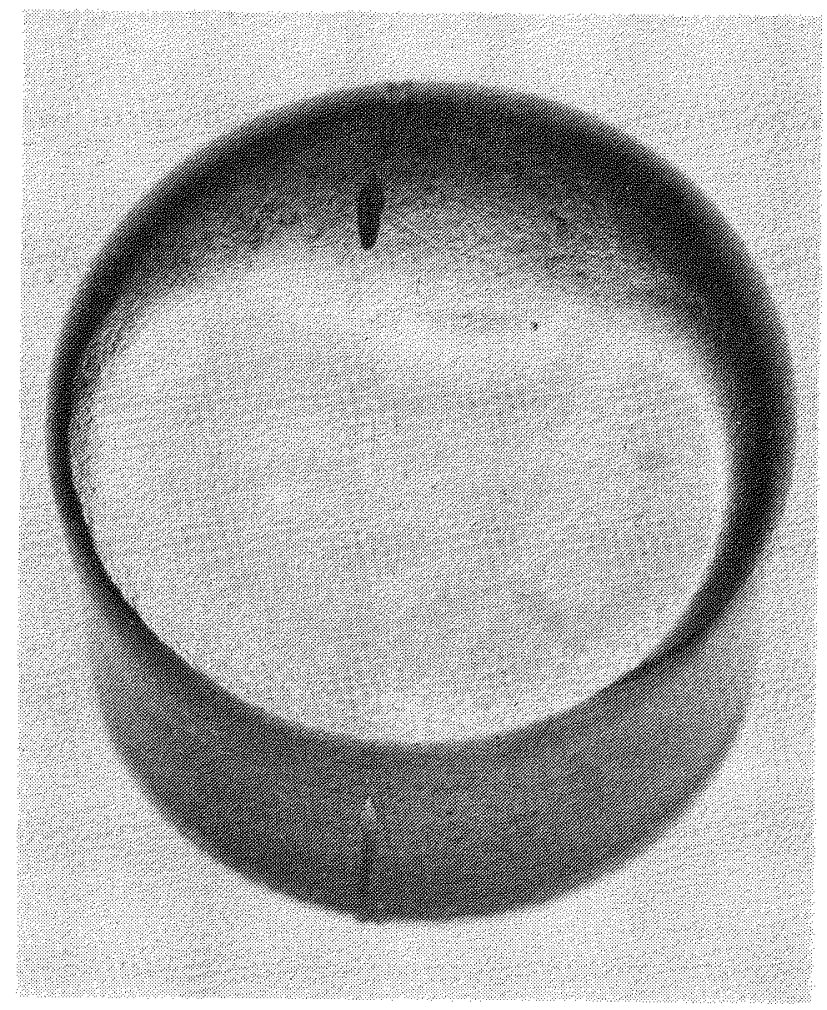

FIGURE 80 - Continued. 


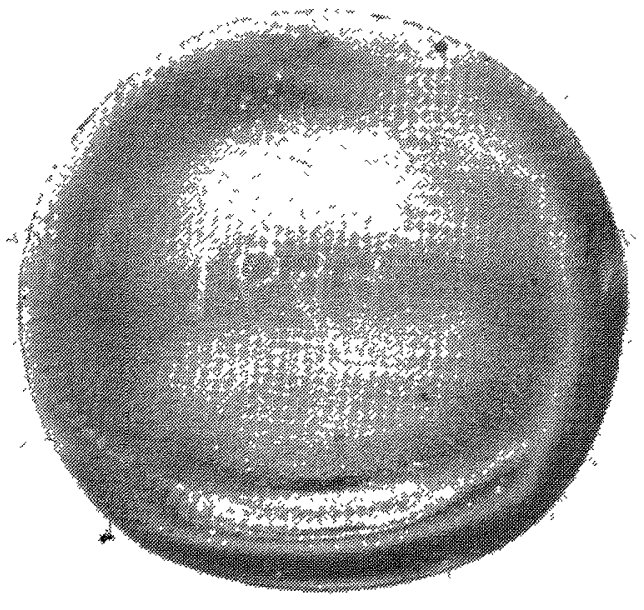

(A)

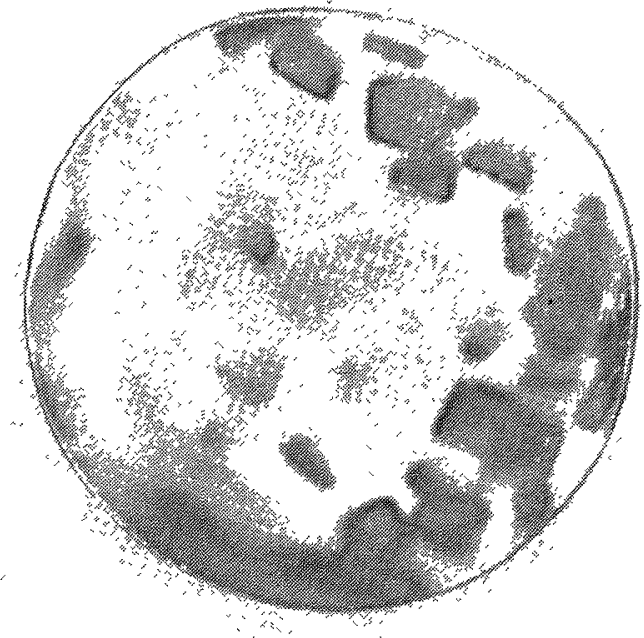

(B)

FIGURE 81 - WMYT-05 shim. As a result of the impact, the impression of the serial number and weld underbead of the liner cap were left on the top side of the shim (A) indicating that the shim was ductile. The discolored zones on the underside of the shim (B) occurred at locations of contact with the yttrium chips during pretreatment. 

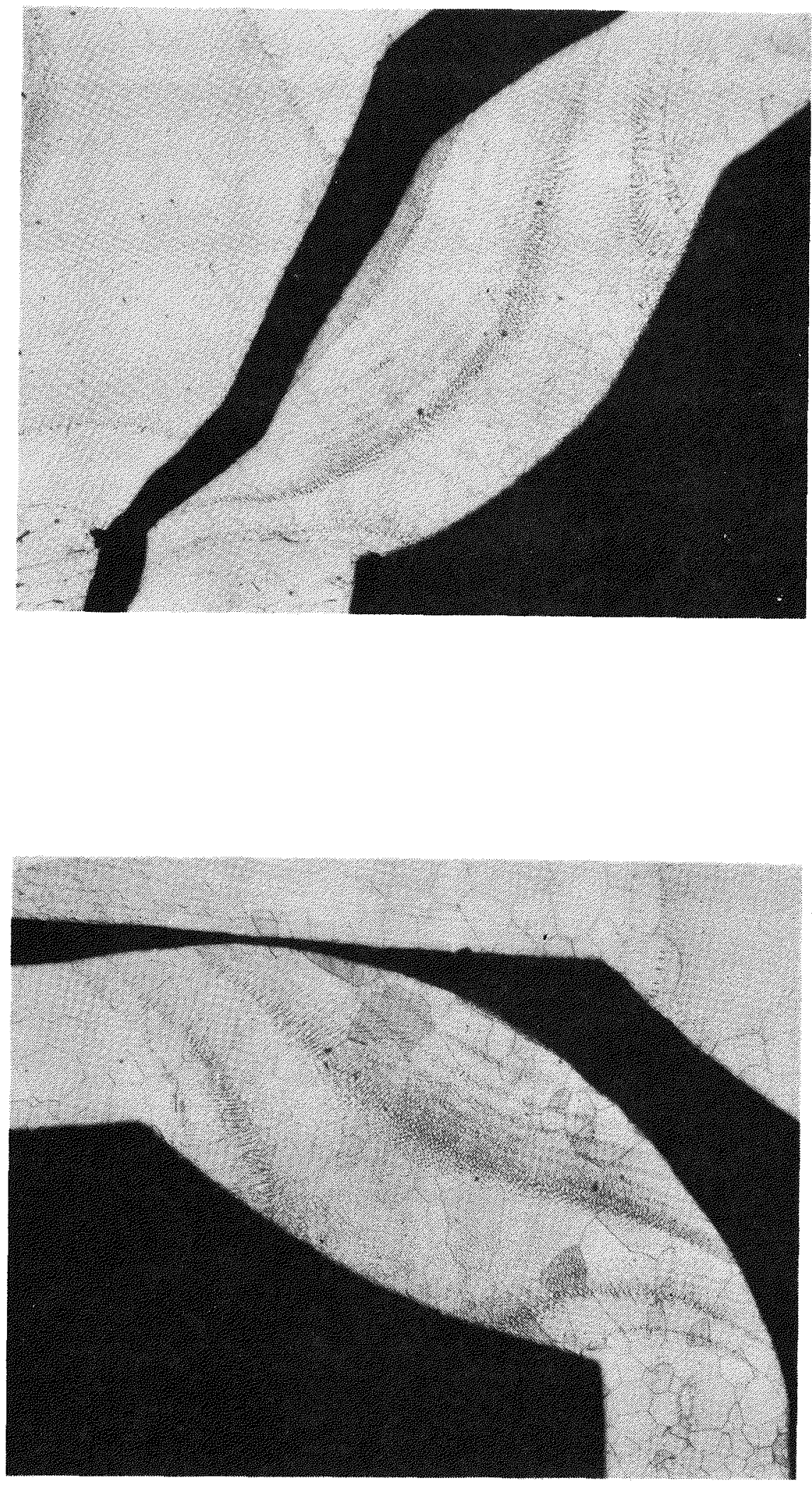

FIGURE 82 - WMYT-05 cross section of liner weld through impact and $180^{\circ}$ of impact. (50X) 


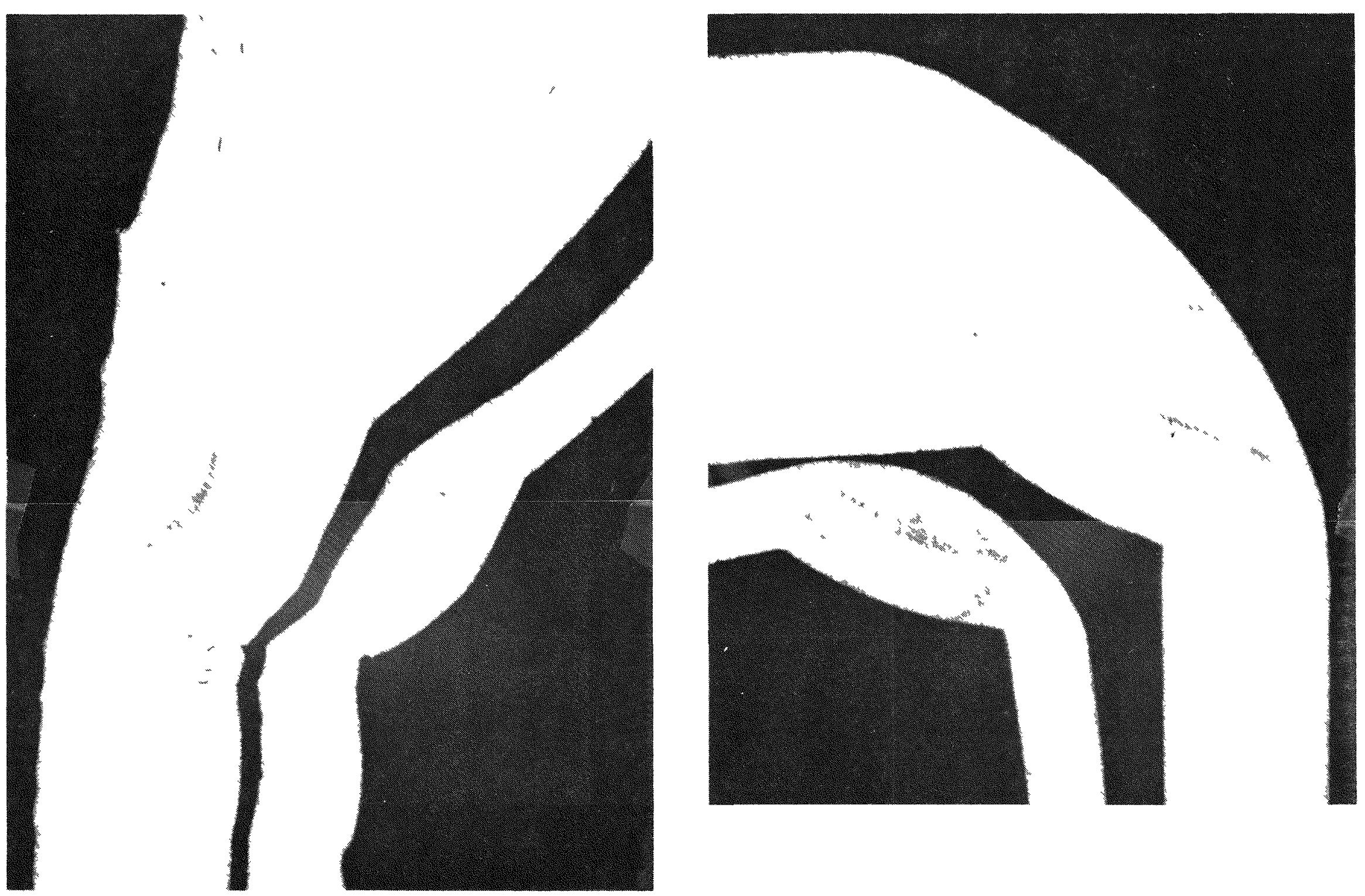

FIGURE 83 - WMYT-05 cross section of liner and strength member welds through impact face and $180^{\circ}$ of impact. $(27.5 X)$ 

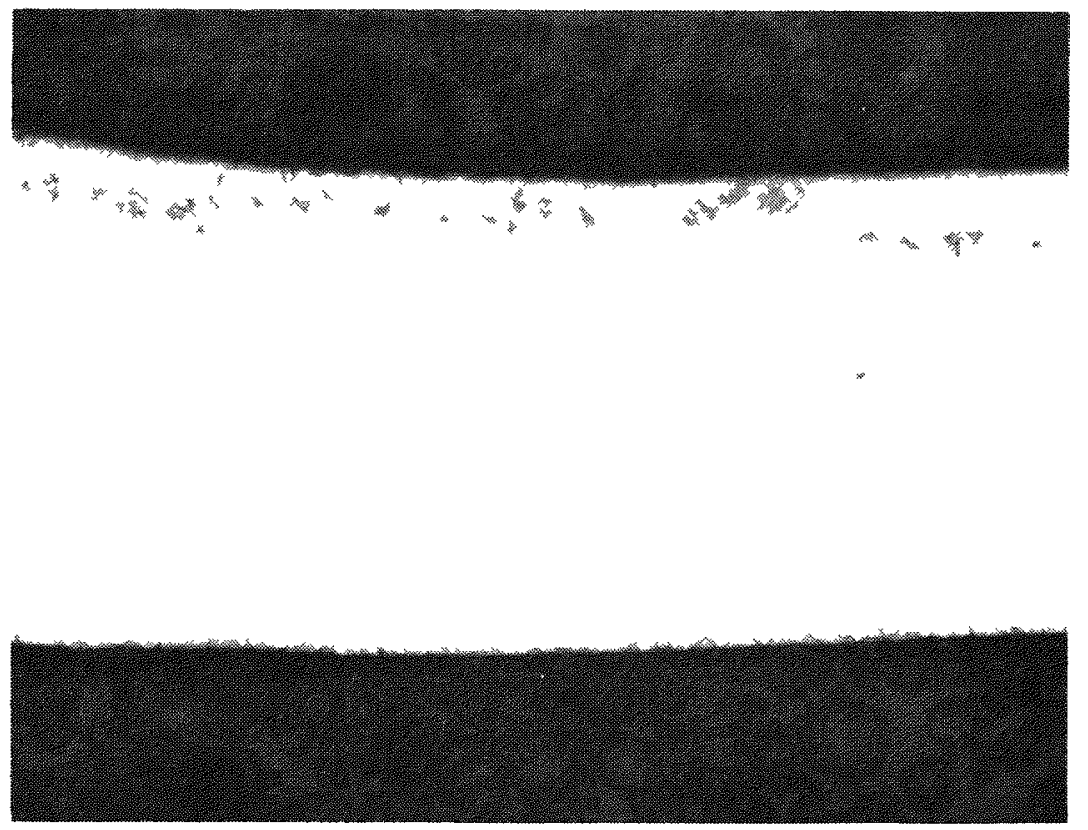

FIGURE 84 - WMYT-05 (100X) cross section of dome end (see Figure 86)
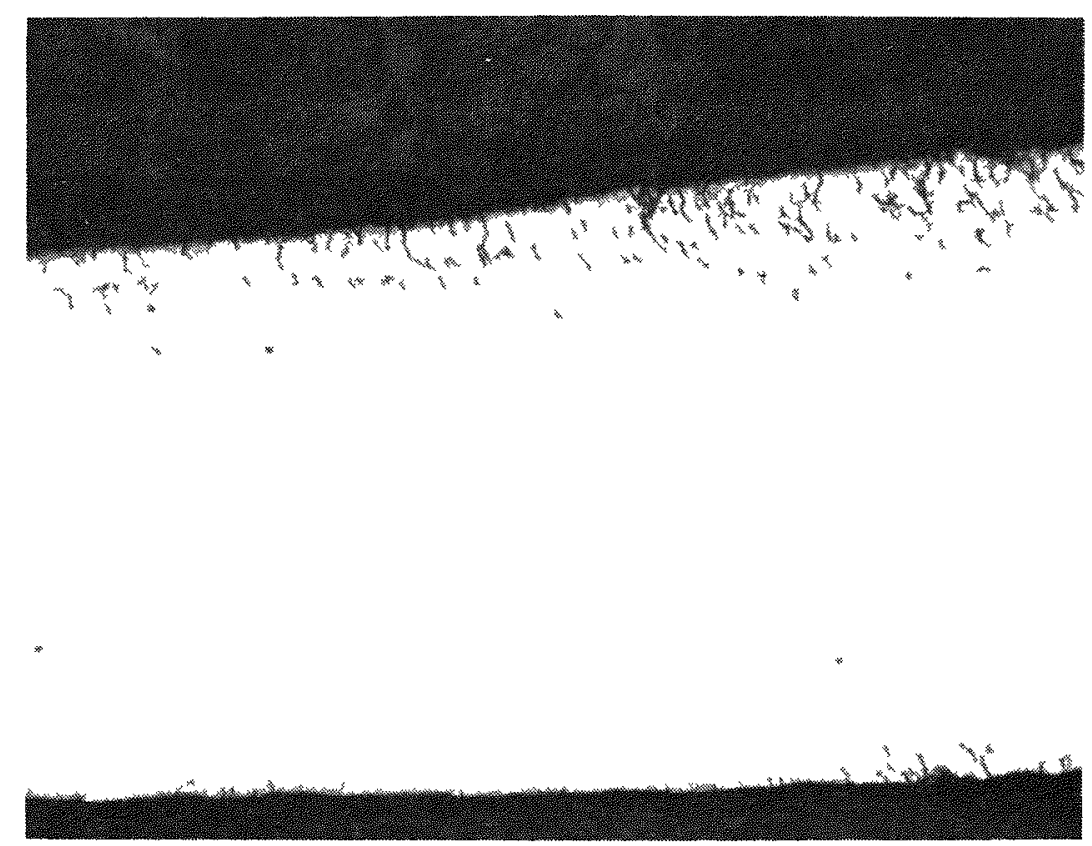

FIGURE 85 - WMYT-05 (100X)cross section of dome end through impact face (see Figure 86) 

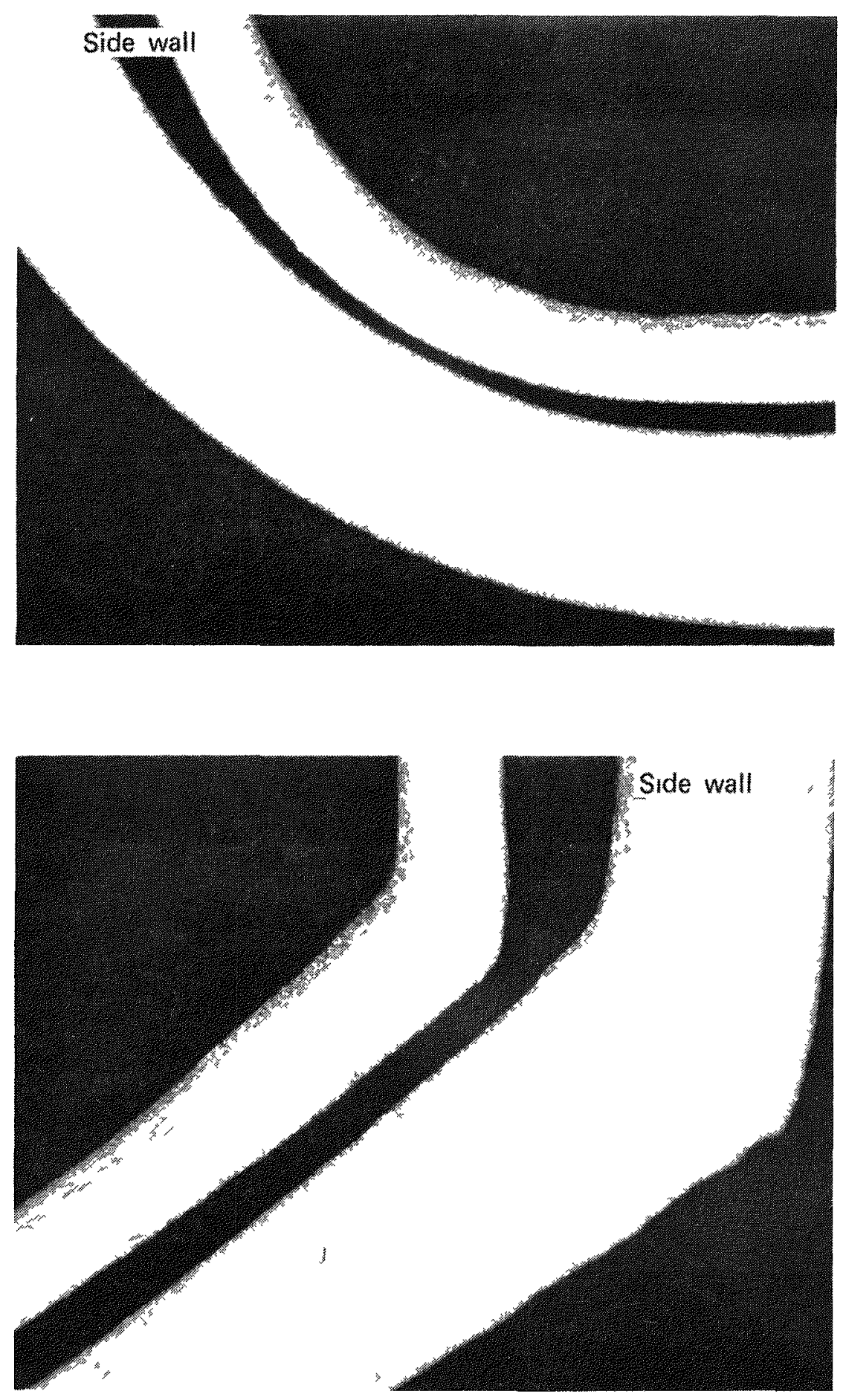

FIGURE 86 - WMYT-05 cross-section of liner and strength member (dome end) through impact face and $180^{\circ}$ of impact $(275 \mathrm{X})$ 

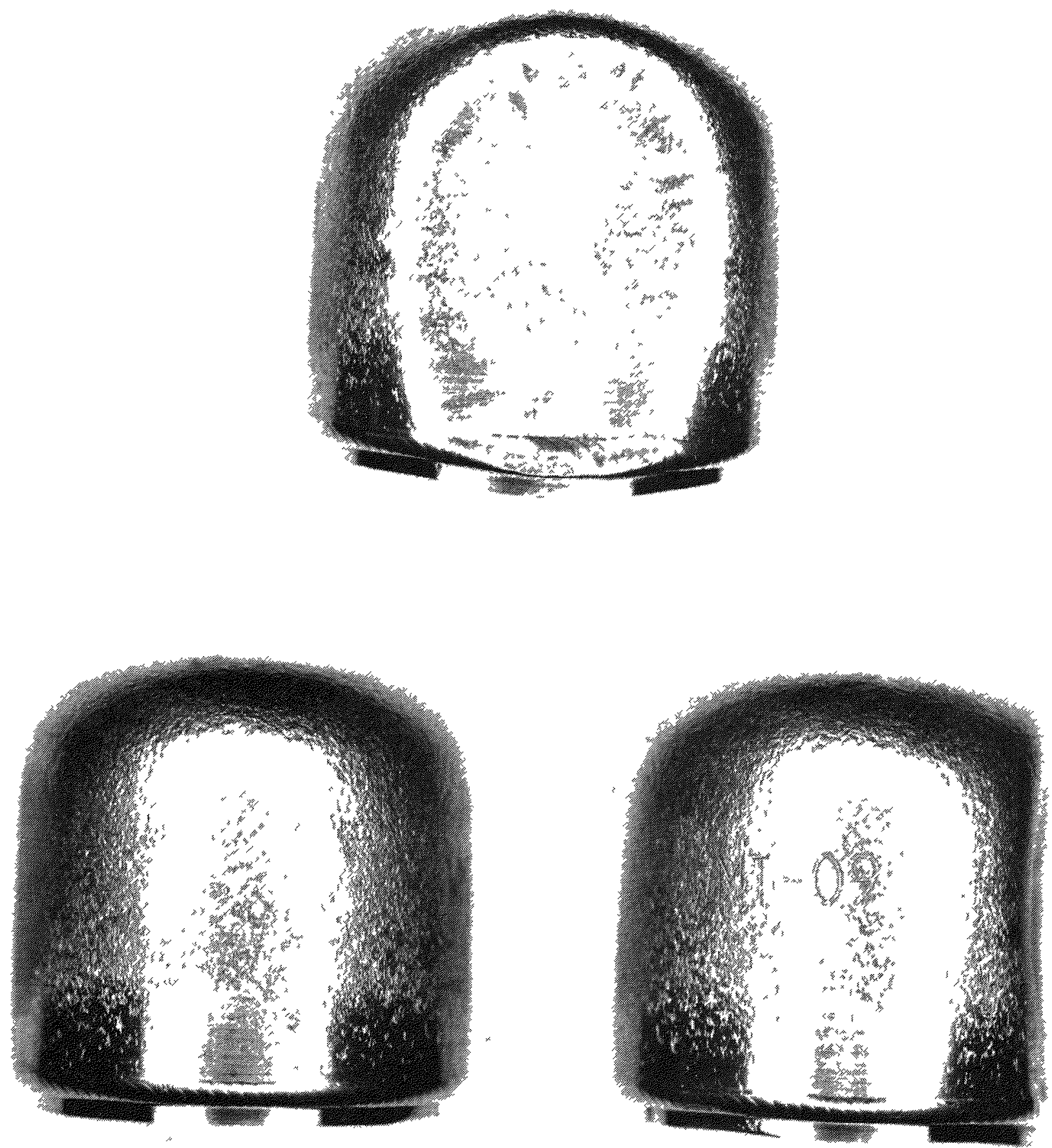

FIGURE 87 - Showing condition of WMT-09 clad after first side impact at $82.5 \mathrm{~m} / \mathrm{sec}$. 

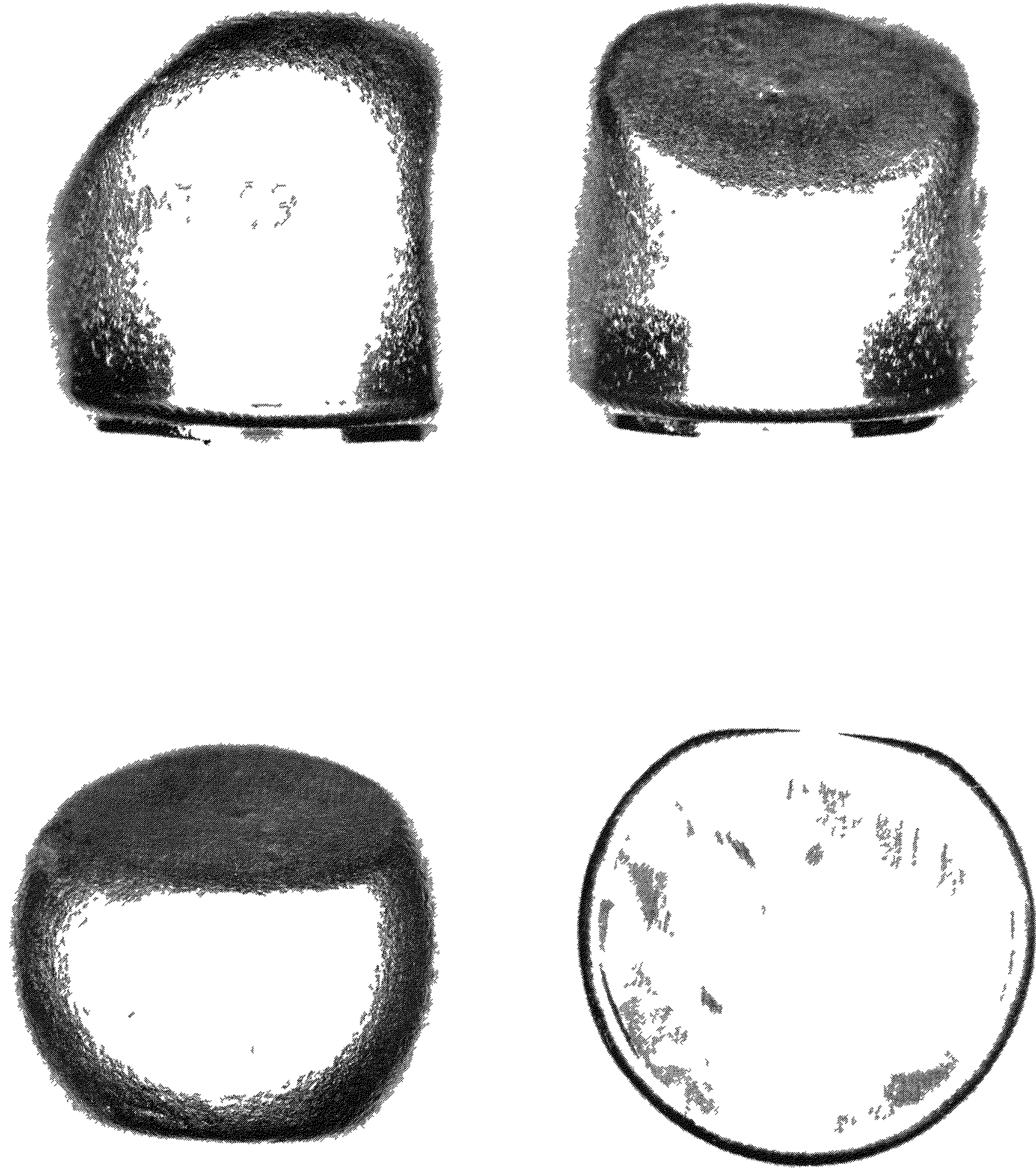

FIGURE 88 - Showing condition of WMT-09 clad after second impact Side was impacted at 825 $\mathrm{m} / \mathrm{sec}$ and the dome corner at $791 \mathrm{~m} / \mathrm{sec}$ 

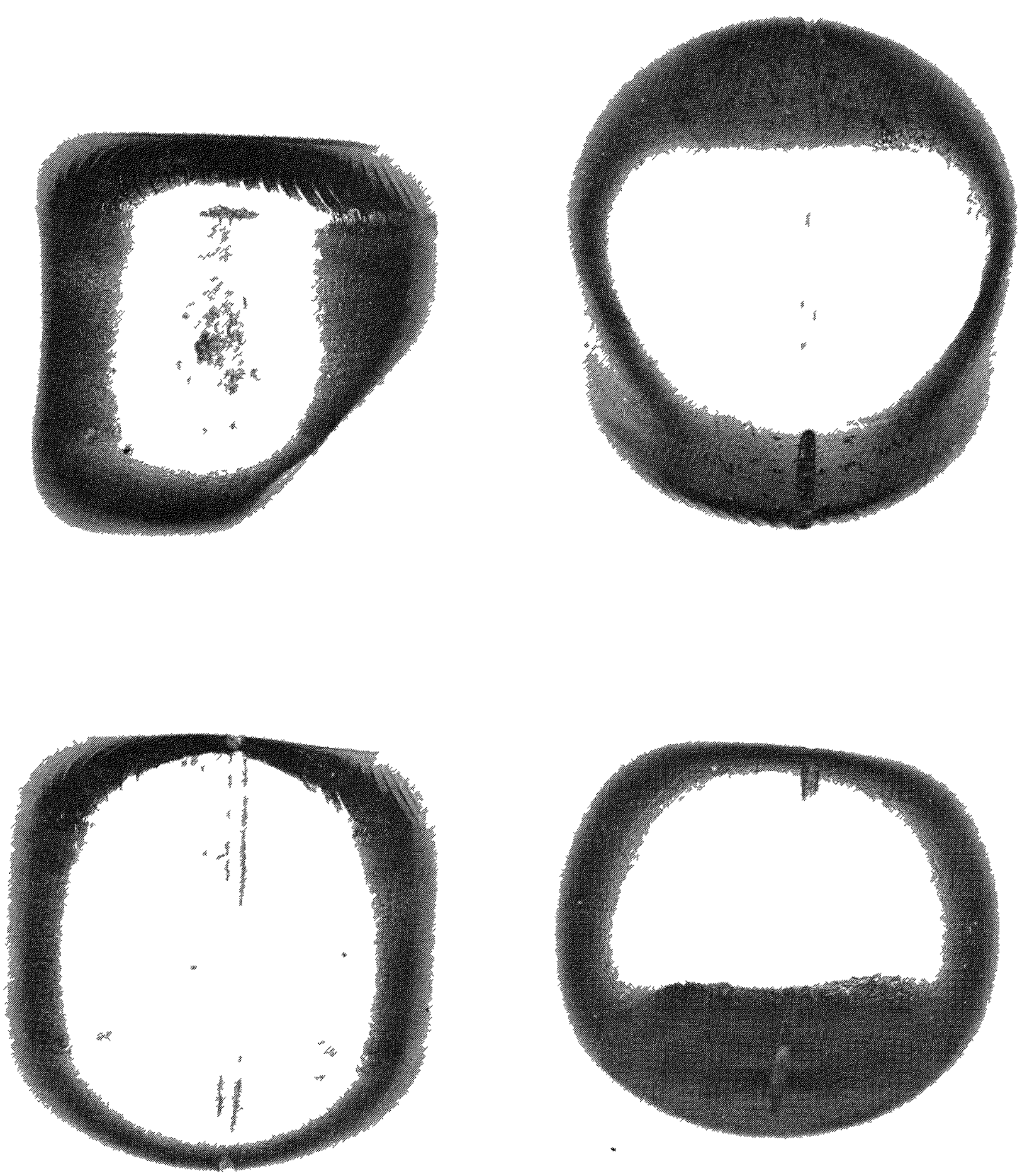

FIGURE 89 - Four views of WMT-09 strength member Strength member in good condition without cracks or breach 

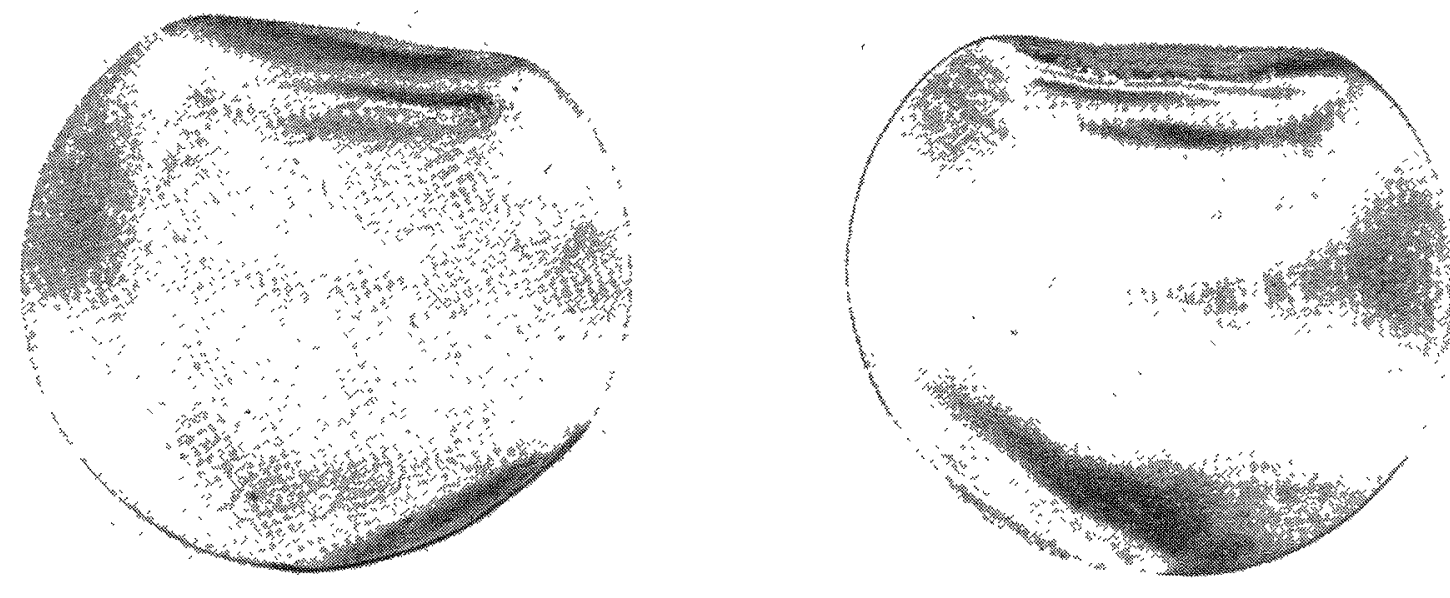

FIGURE 90 - Two views of WMT-09 shim. 

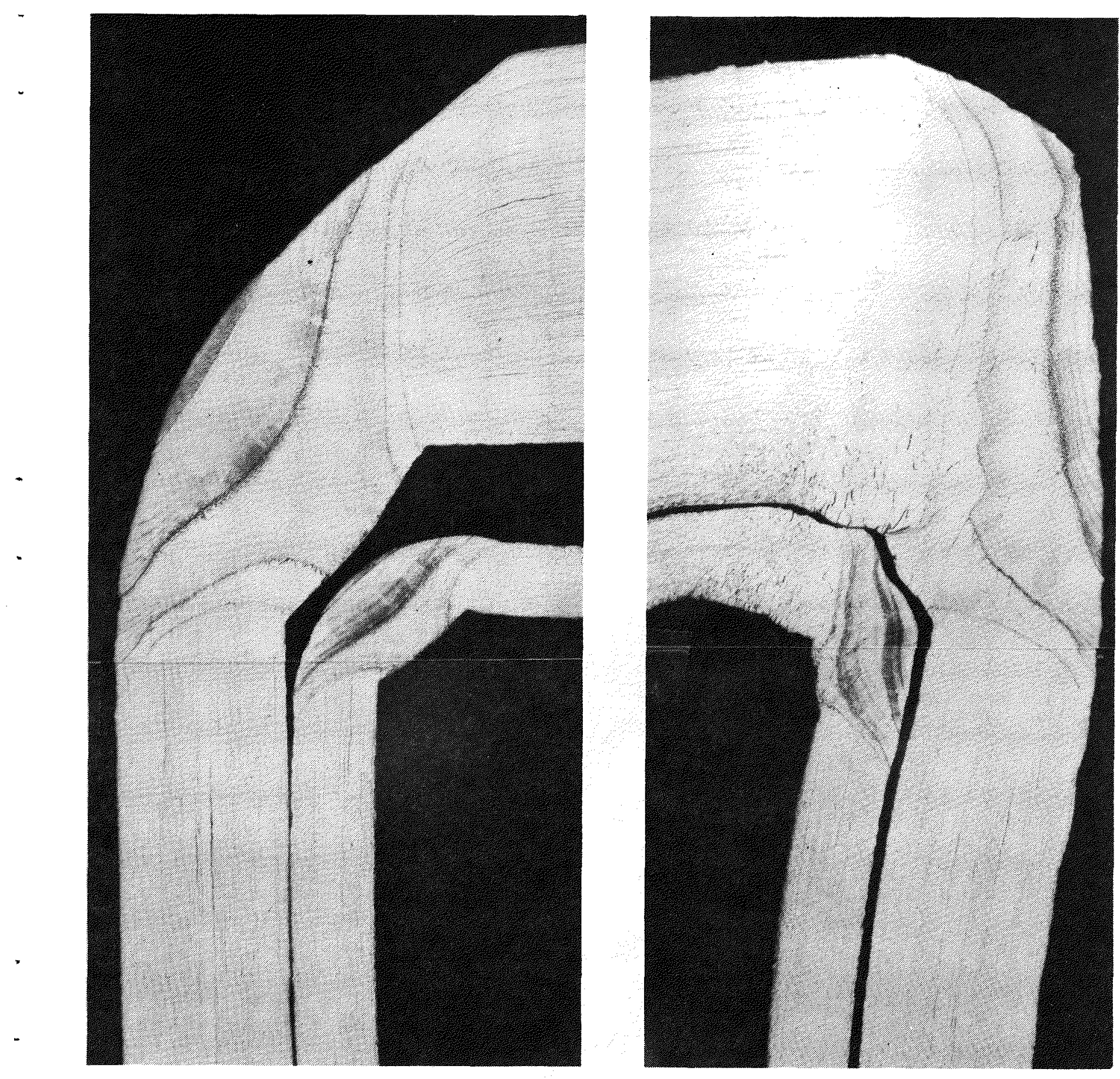

FIGURE 91 - WMT-09 cross section of liner and strength member welds through impact face and $180^{\circ}$ of impact. (27.5X) 

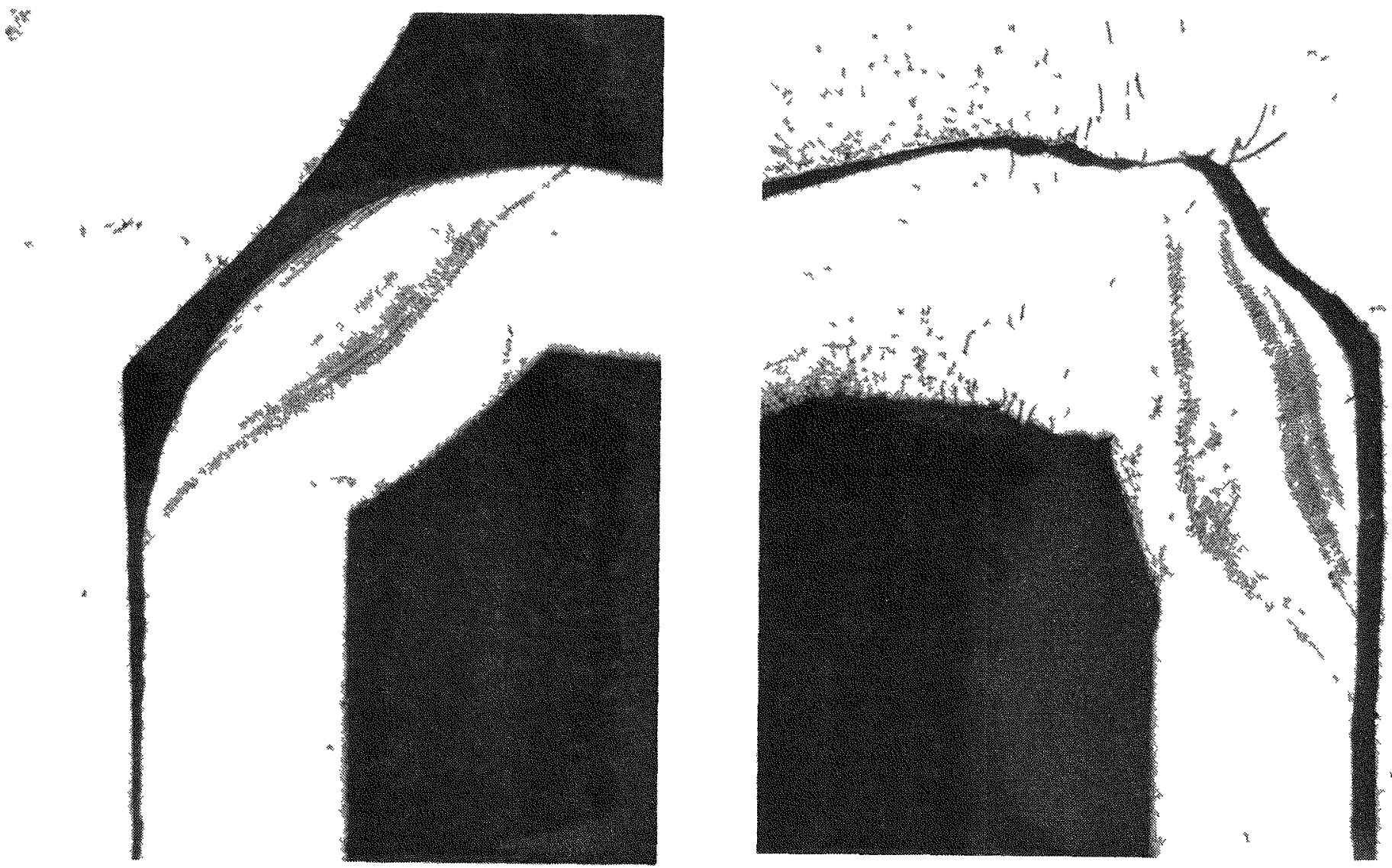

FIGURE 92 - WMT-09 cross section of liner weld through impact face and $180^{\circ}$ of impact (50X) 


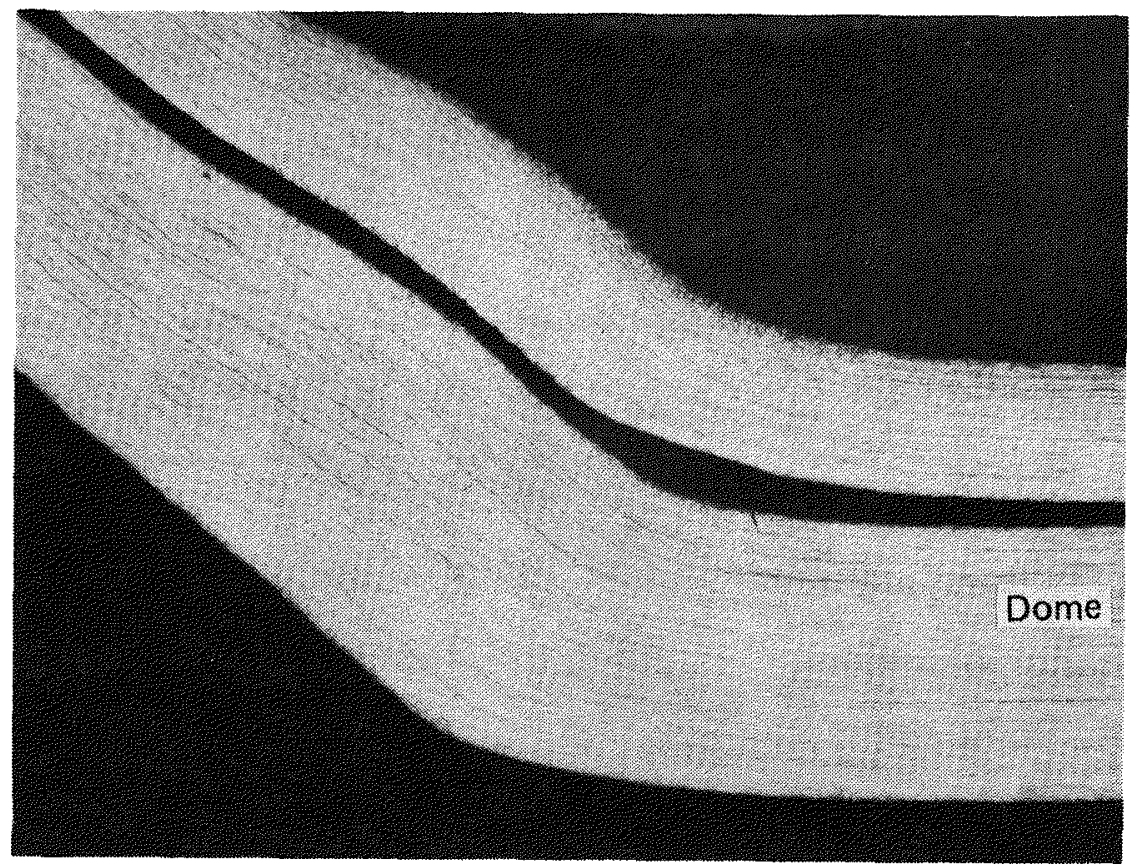

FIGURE 93 - WMT-09 cross section of liner and strength member at dome end in good condition without cracks or breach (27.5X) 

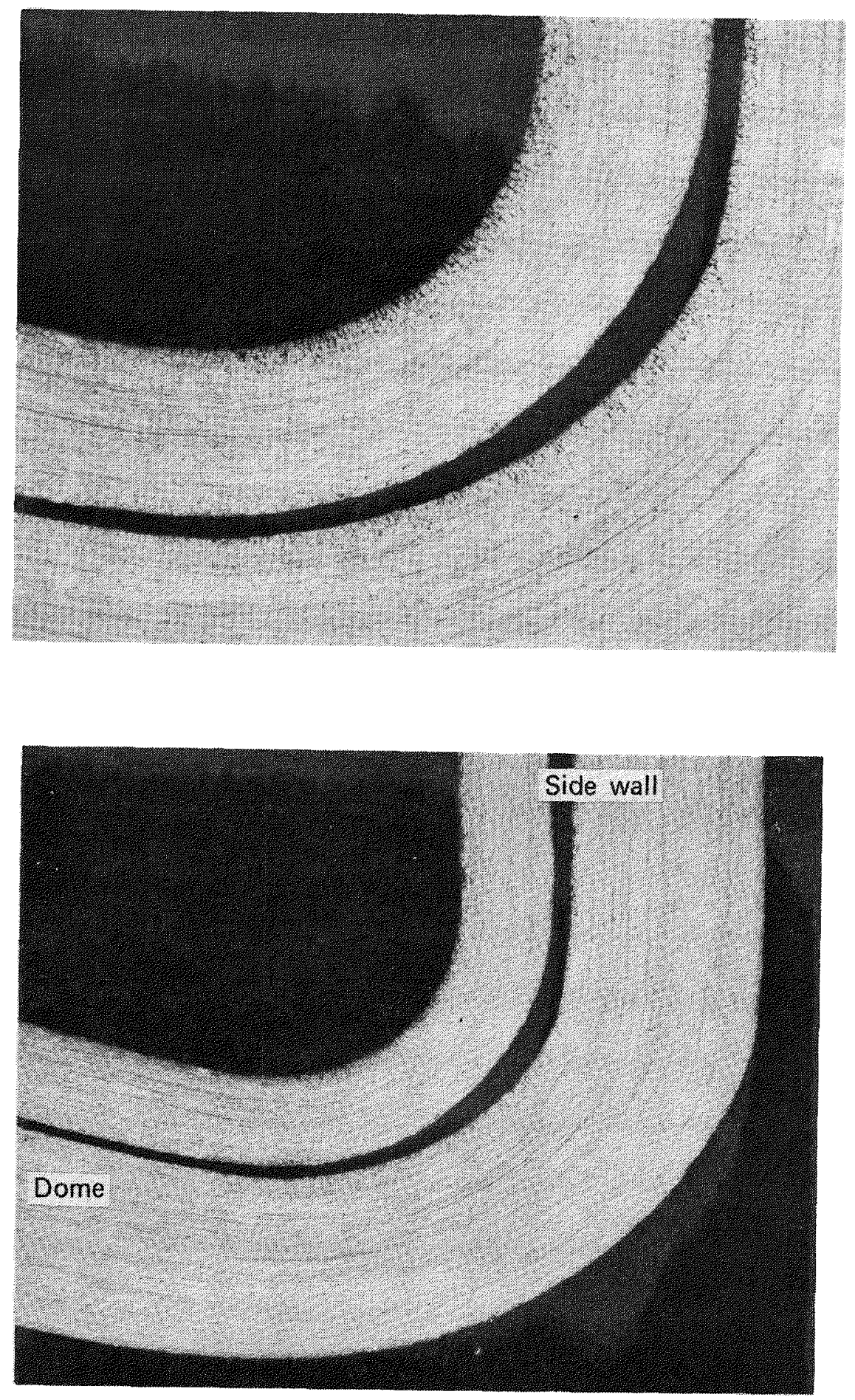

FIGURE 94 - WMT-09 liner dome end. (50X) 

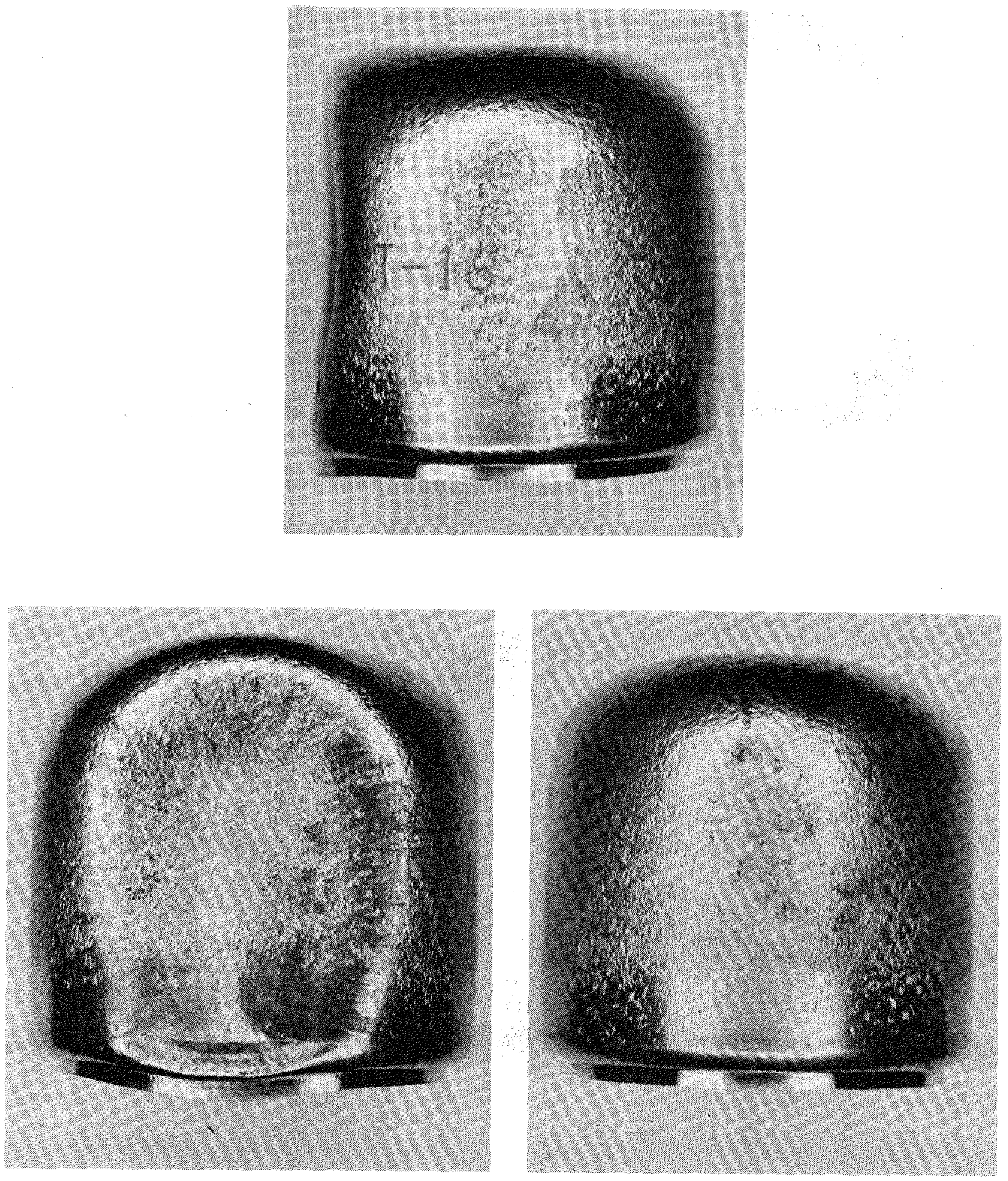

FIGURE 95 - Three views of WMT-16 after first impact at $81.7 \mathrm{~m} / \mathrm{sec}$. 

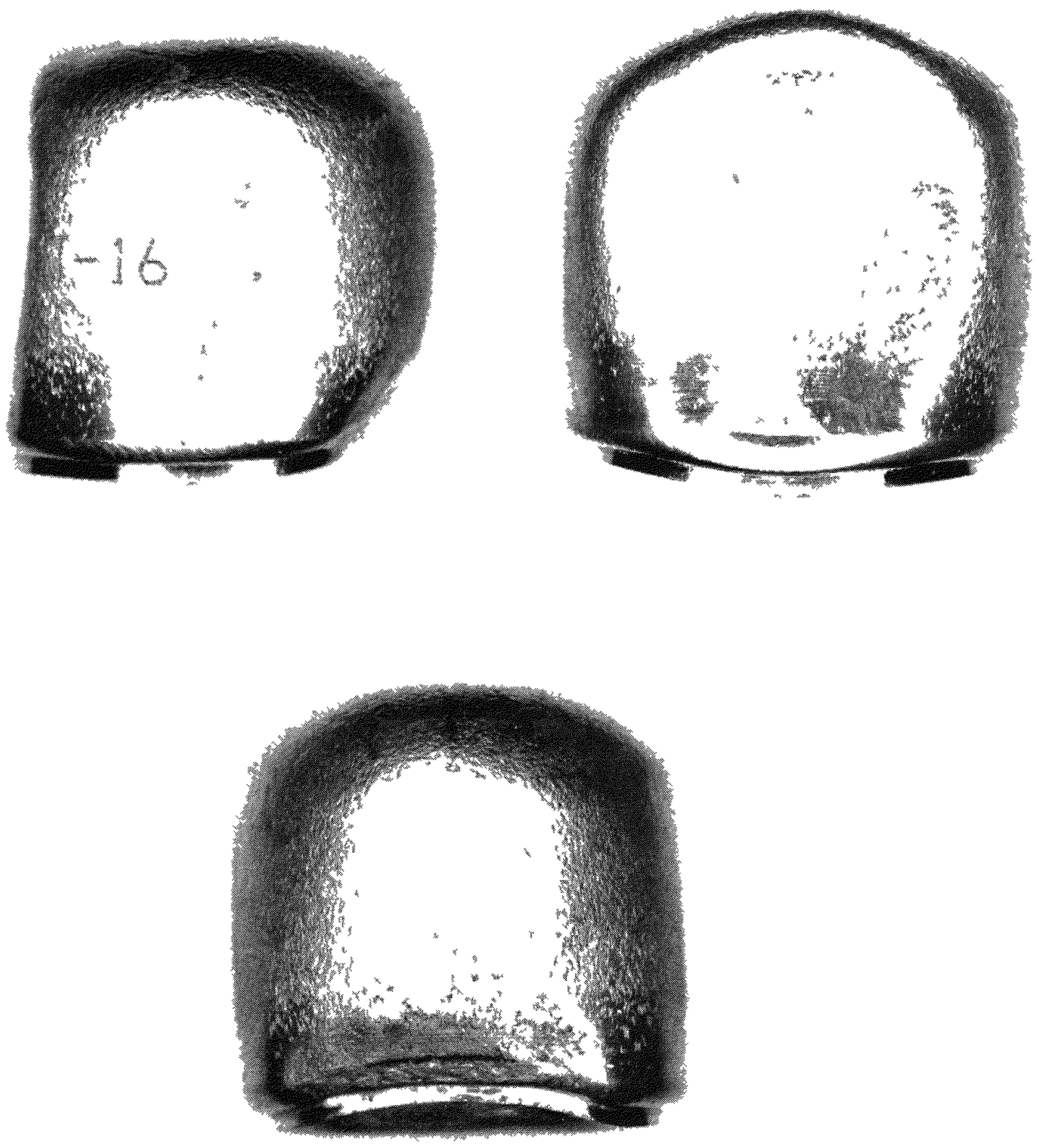

FIGURE 96 - Five views of WMT-16 after second impact A side was impacted at $817 \mathrm{~m} / \mathrm{sec}$ and a cap corner at $791 \mathrm{~m} / \mathrm{sec}$ 

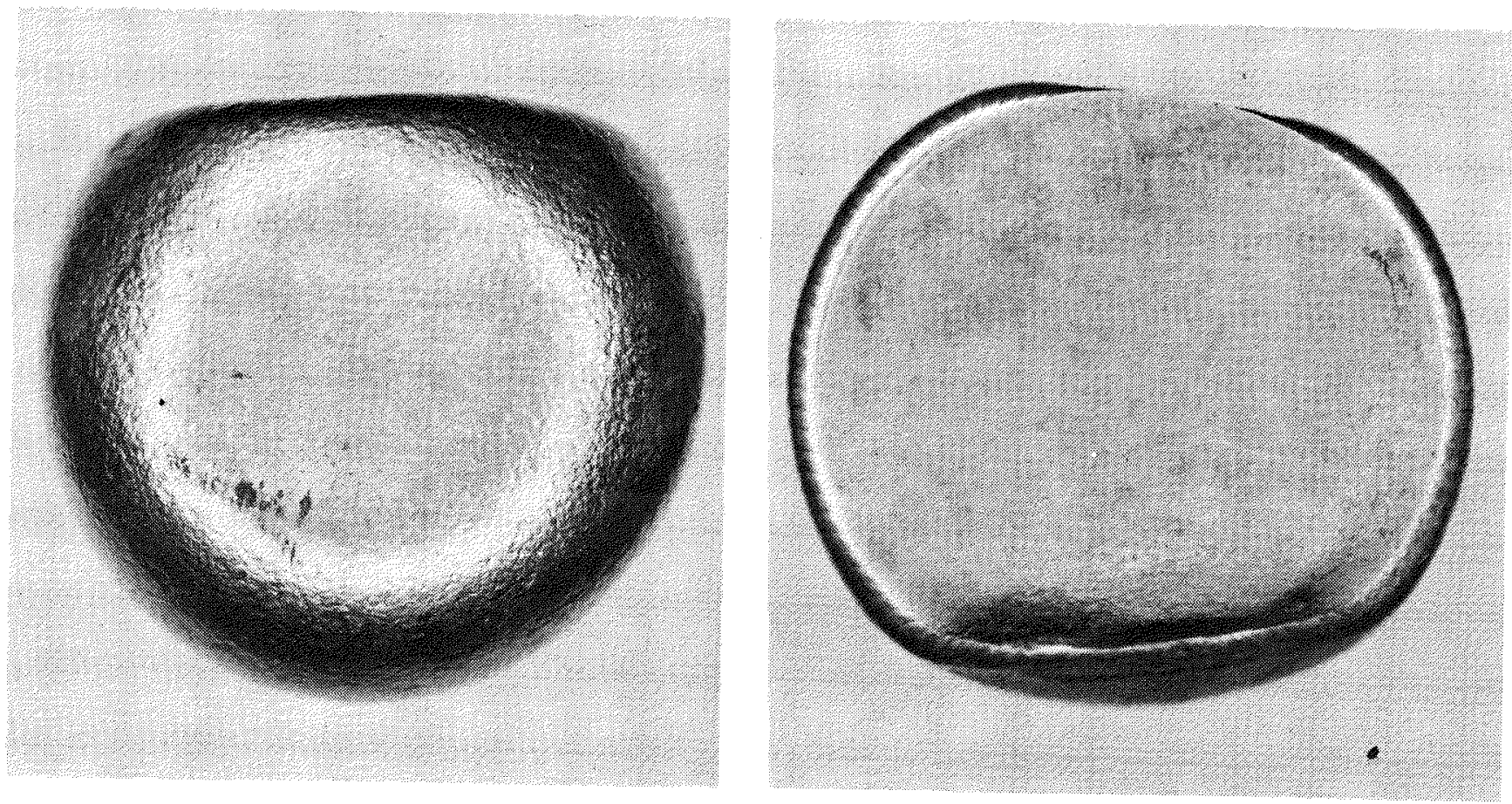

FIGURE 96 - Continued 

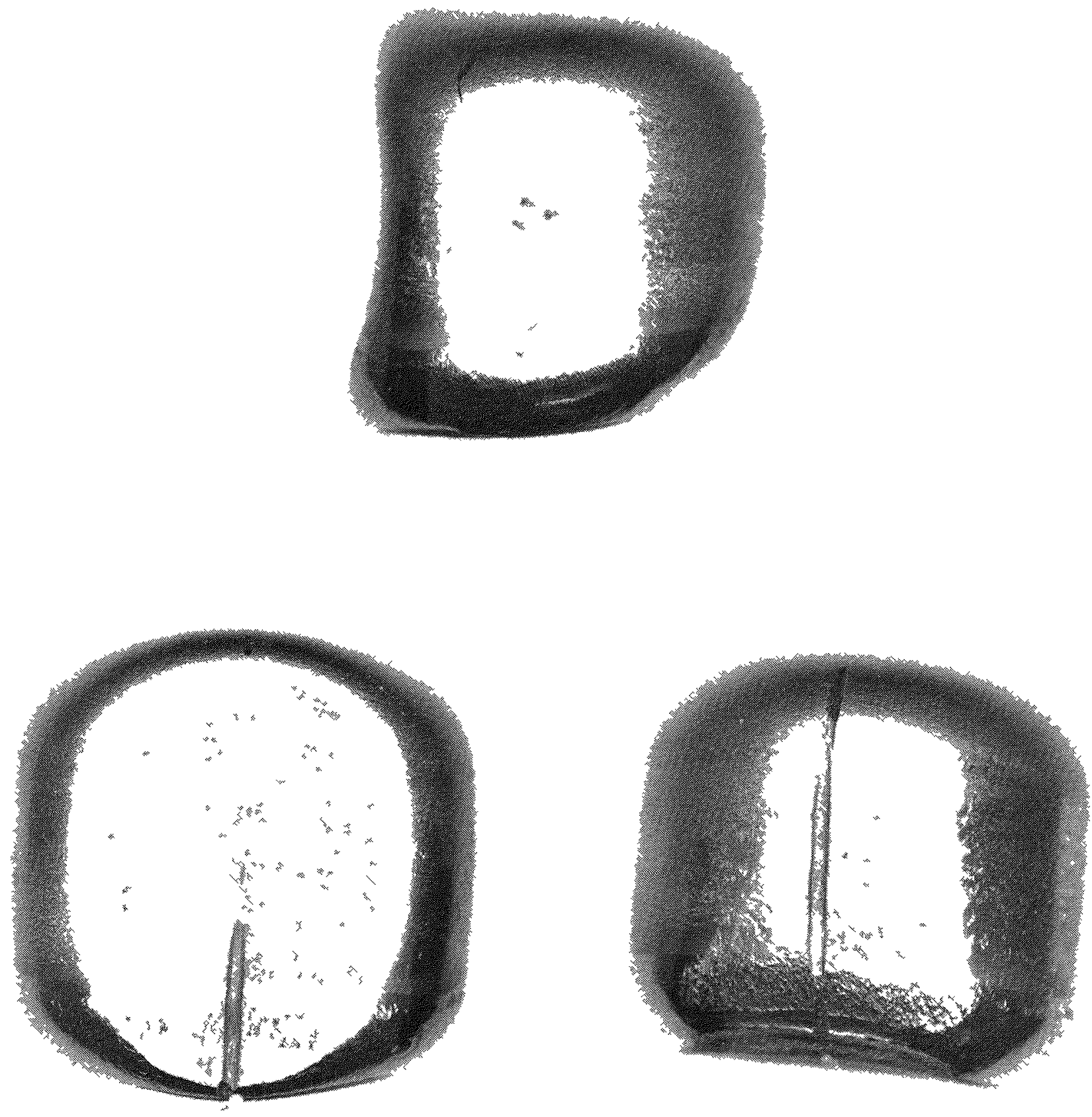

FIGURE 97 - WMT-16 strength member in good condition without cracks or breach 

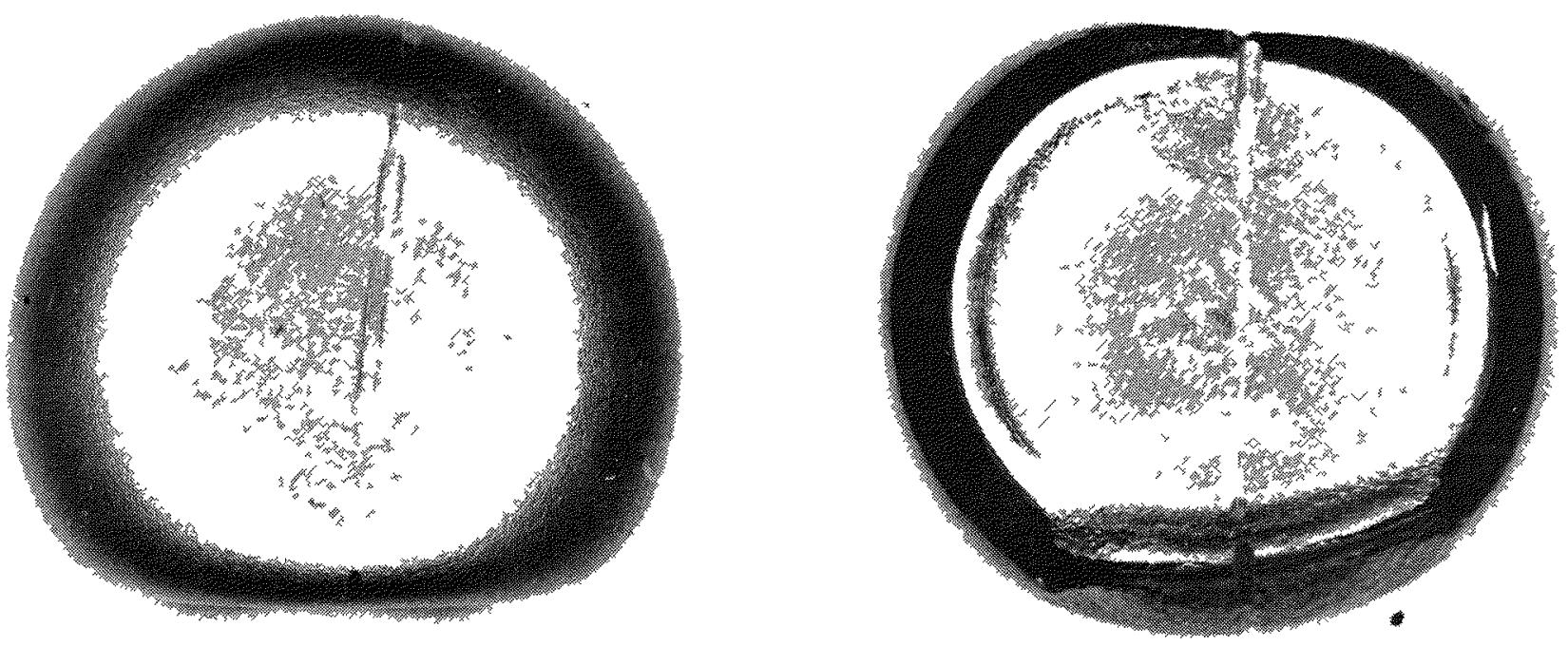

FIGURE 97 - Contınued. 

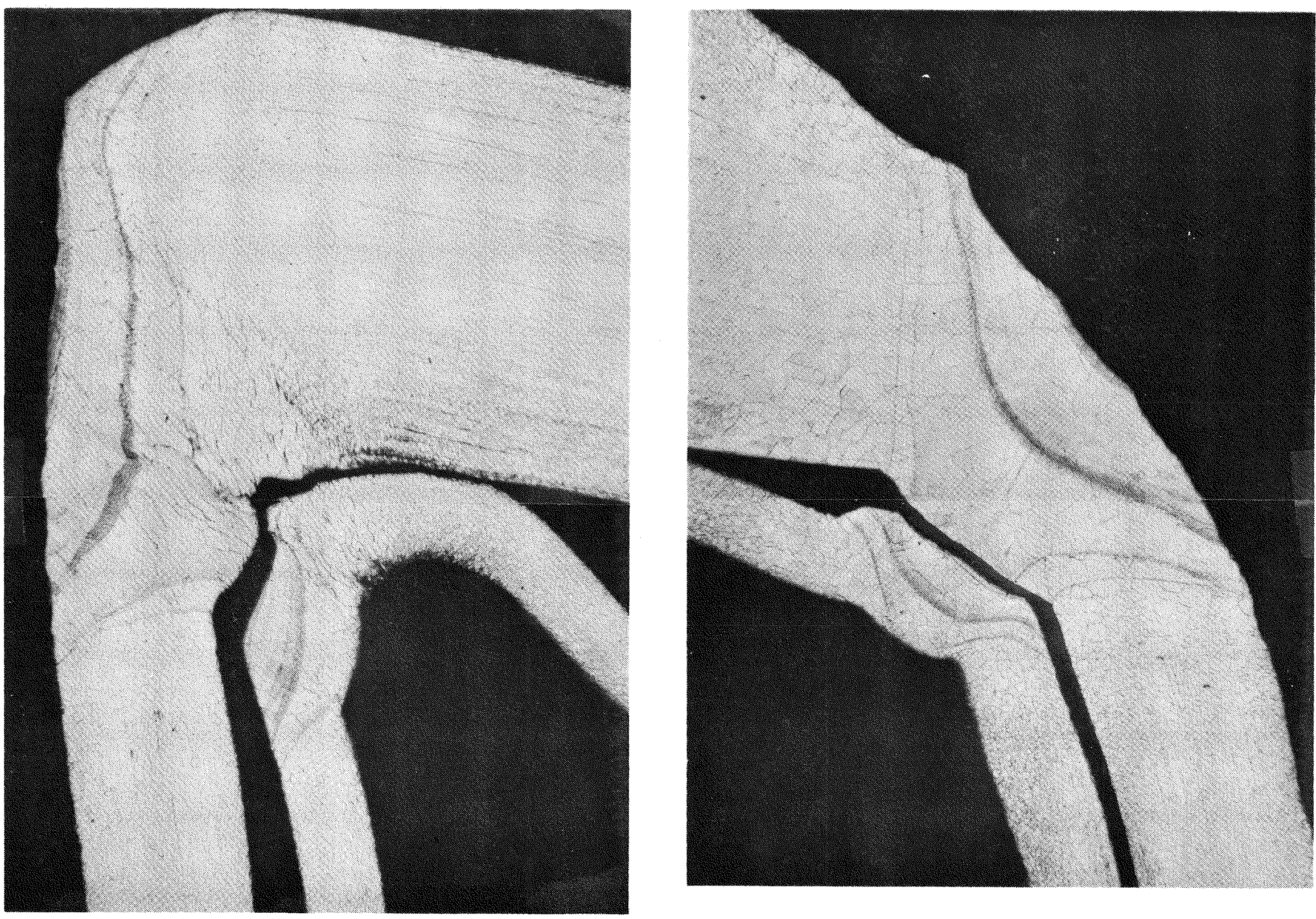

FIGURE 98 - WMT-16 liner and strength member welds through impact faces. (27.5X) 


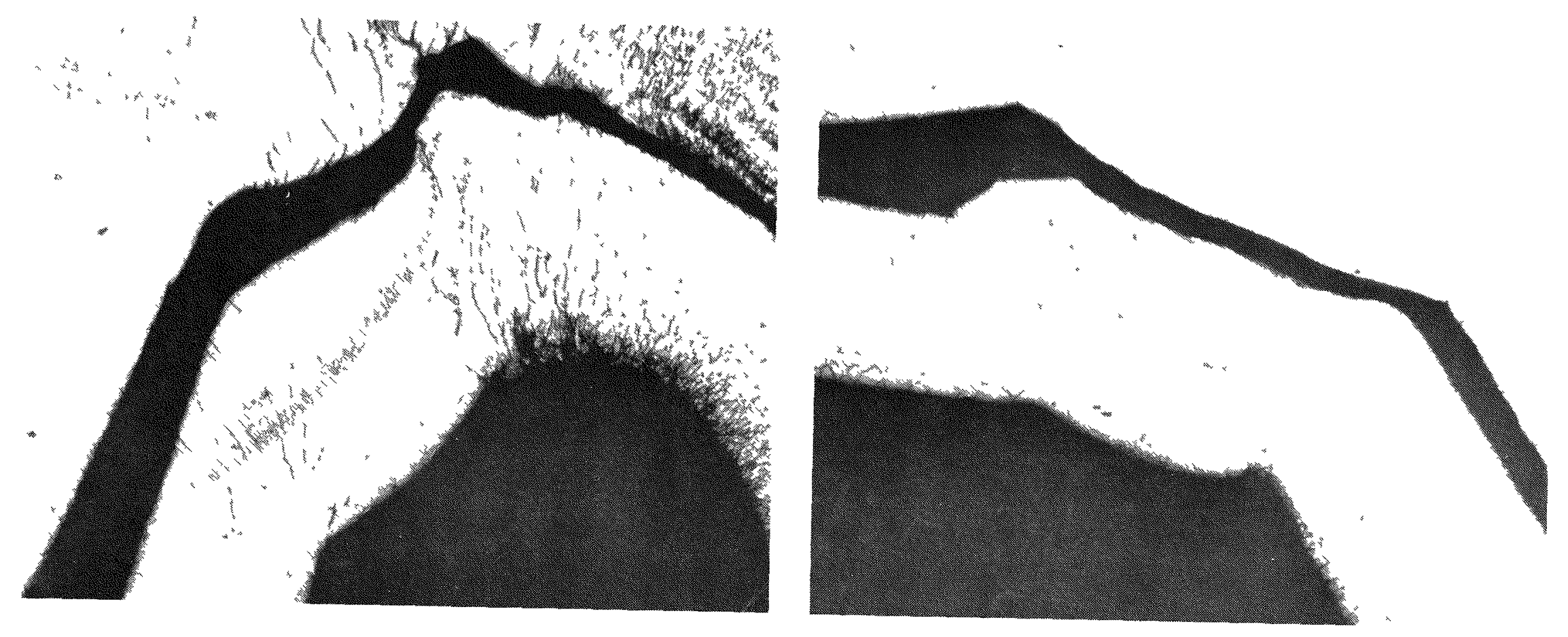




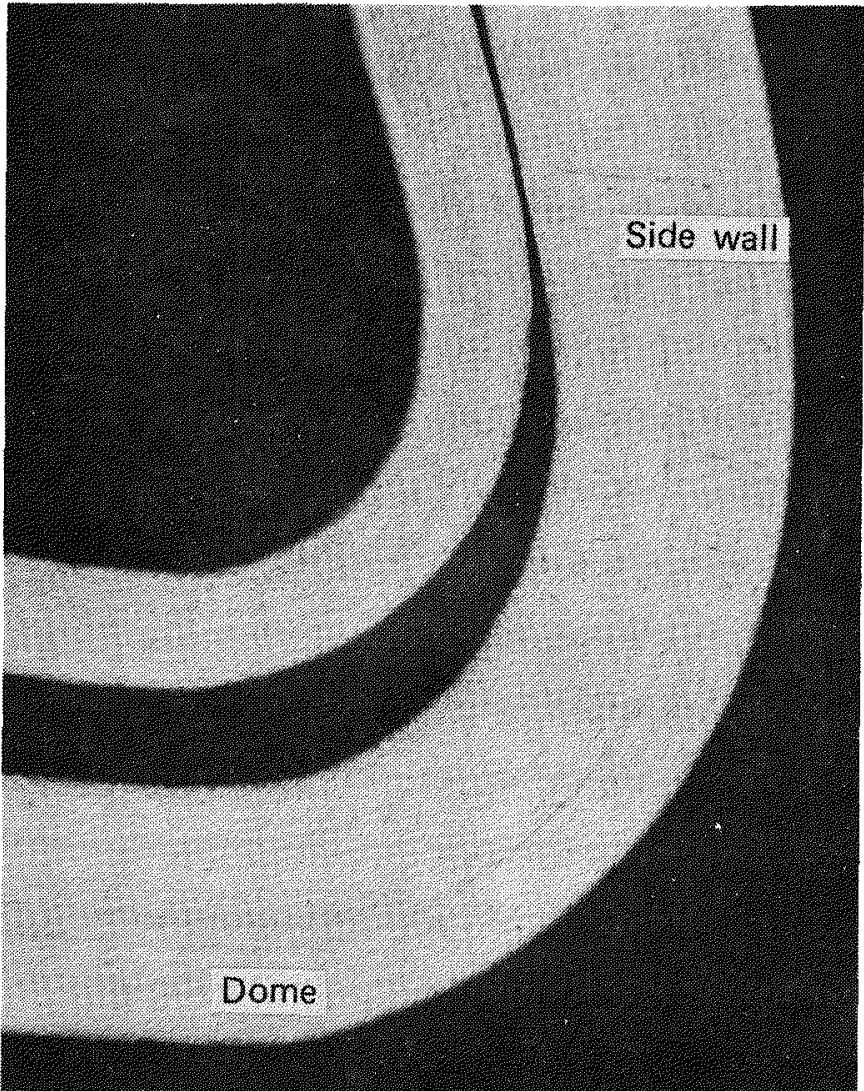

FIGURE 100 - WMT-16 cross section of liner and strength member on the dome end through impact face. (27.5X) 


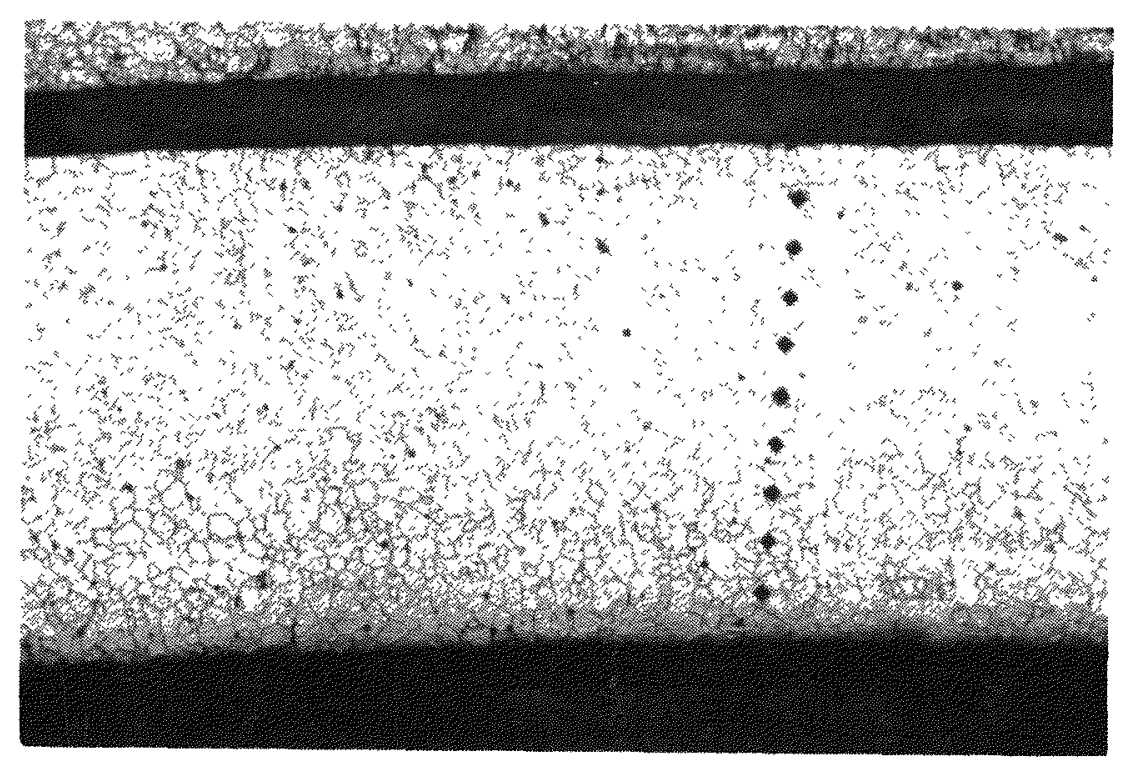

FIGURE 101 - WMT-16 cross section of cap. (100X)

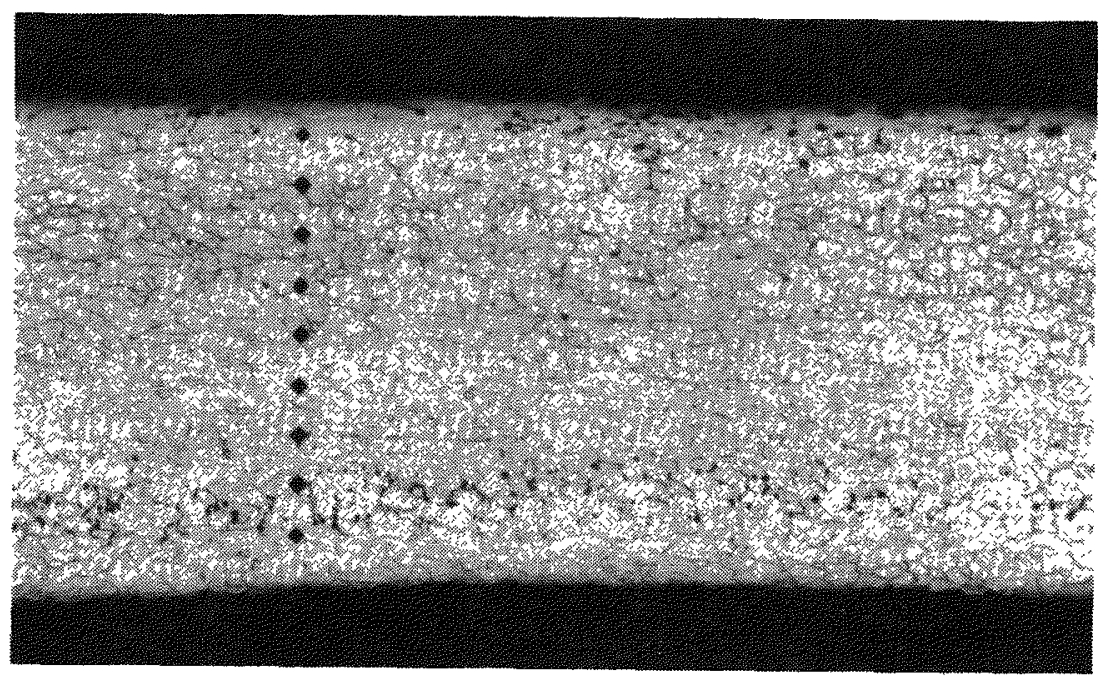

FIGURE 102 - WMT-16 cross section of side wall. (100X) 

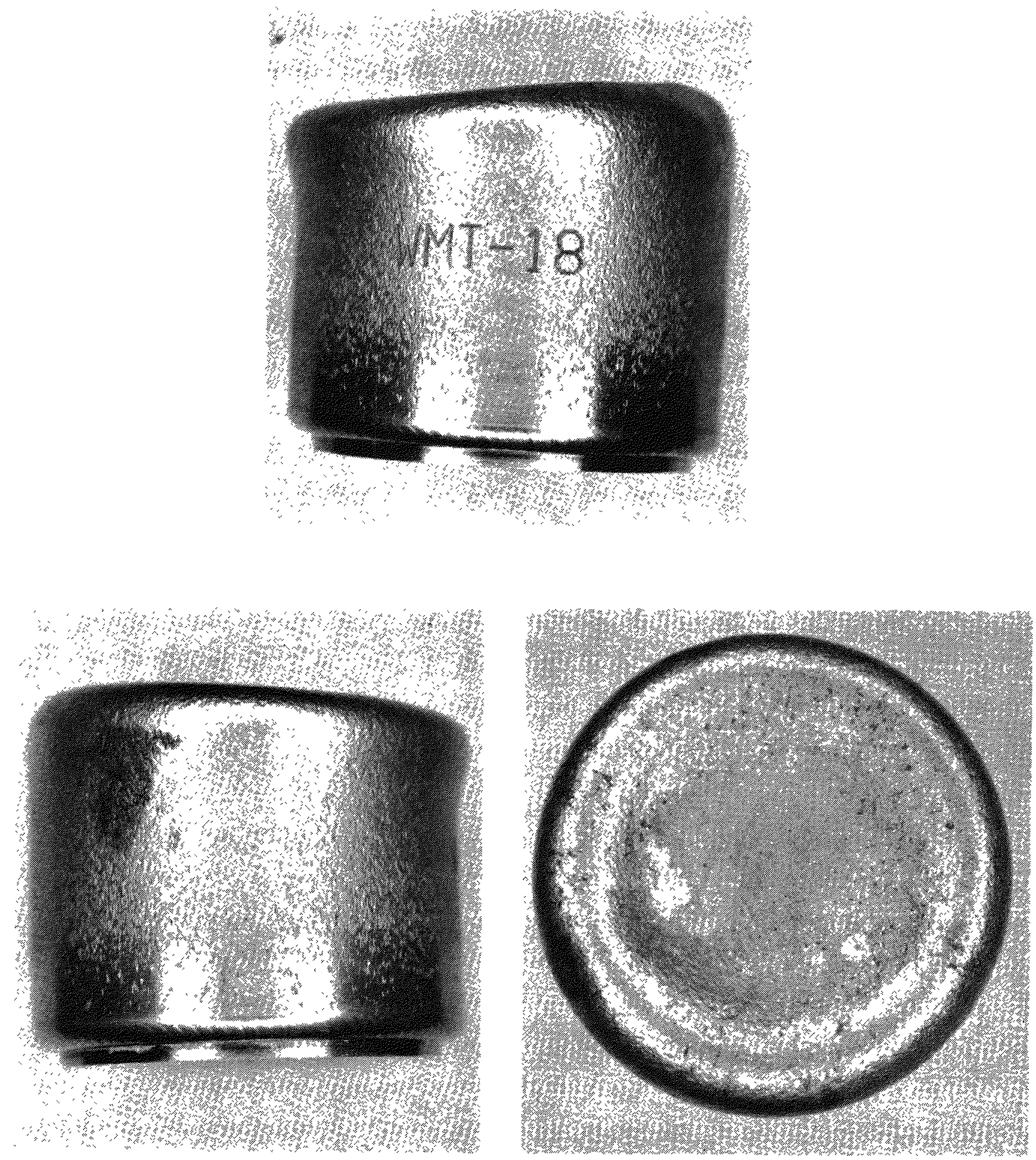

FIGURE 103 - Three views of WMT-18 after first impact at $80.6 \mathrm{~m} / \mathrm{sec}$. 

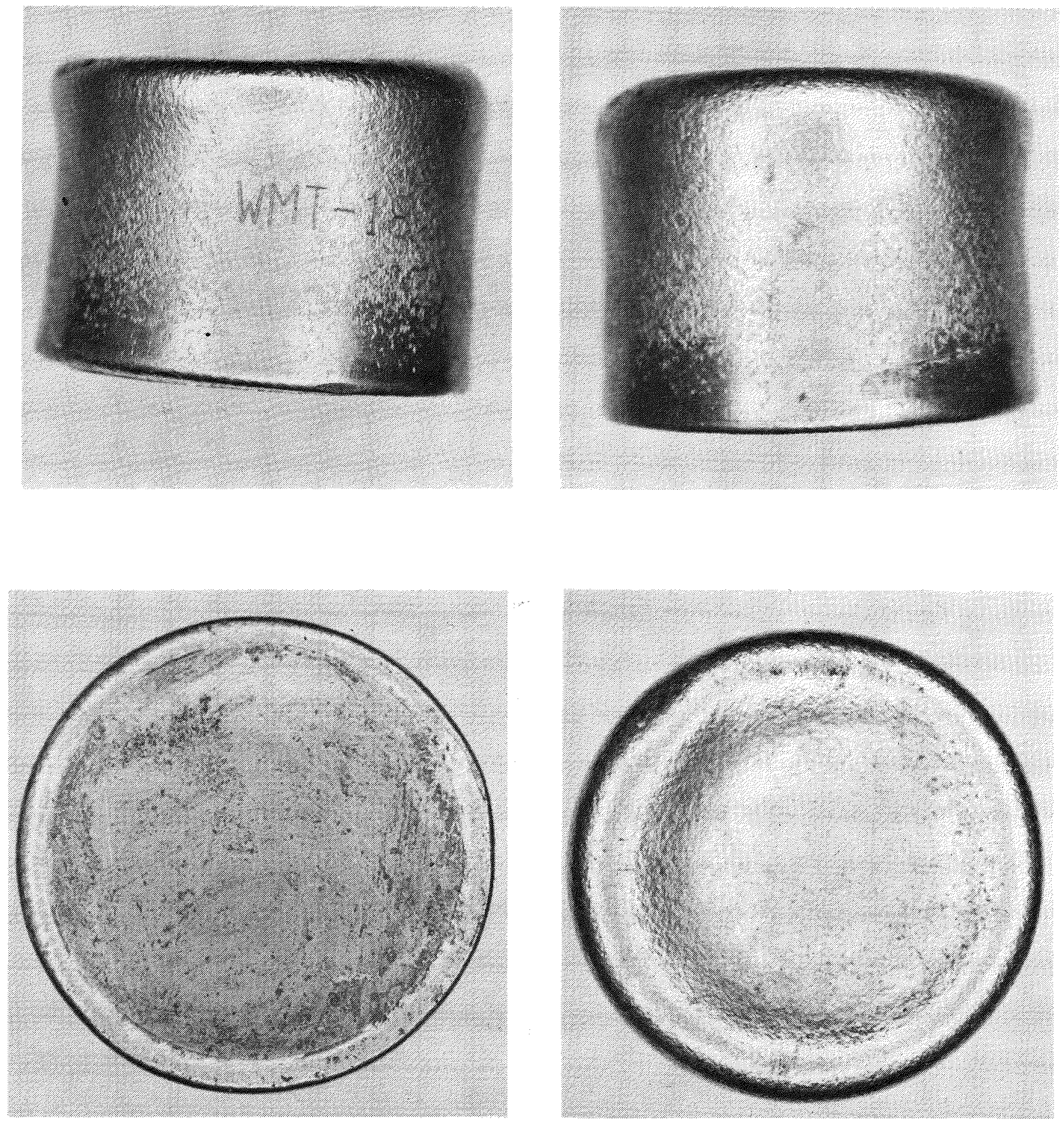

FIGURE 104 - WMT-18, second impact, after the dome was impacted at $80.6 \mathrm{~m} / \mathrm{sec}$ and the cap at $78.4 \mathrm{~m} / \mathrm{sec}$. 

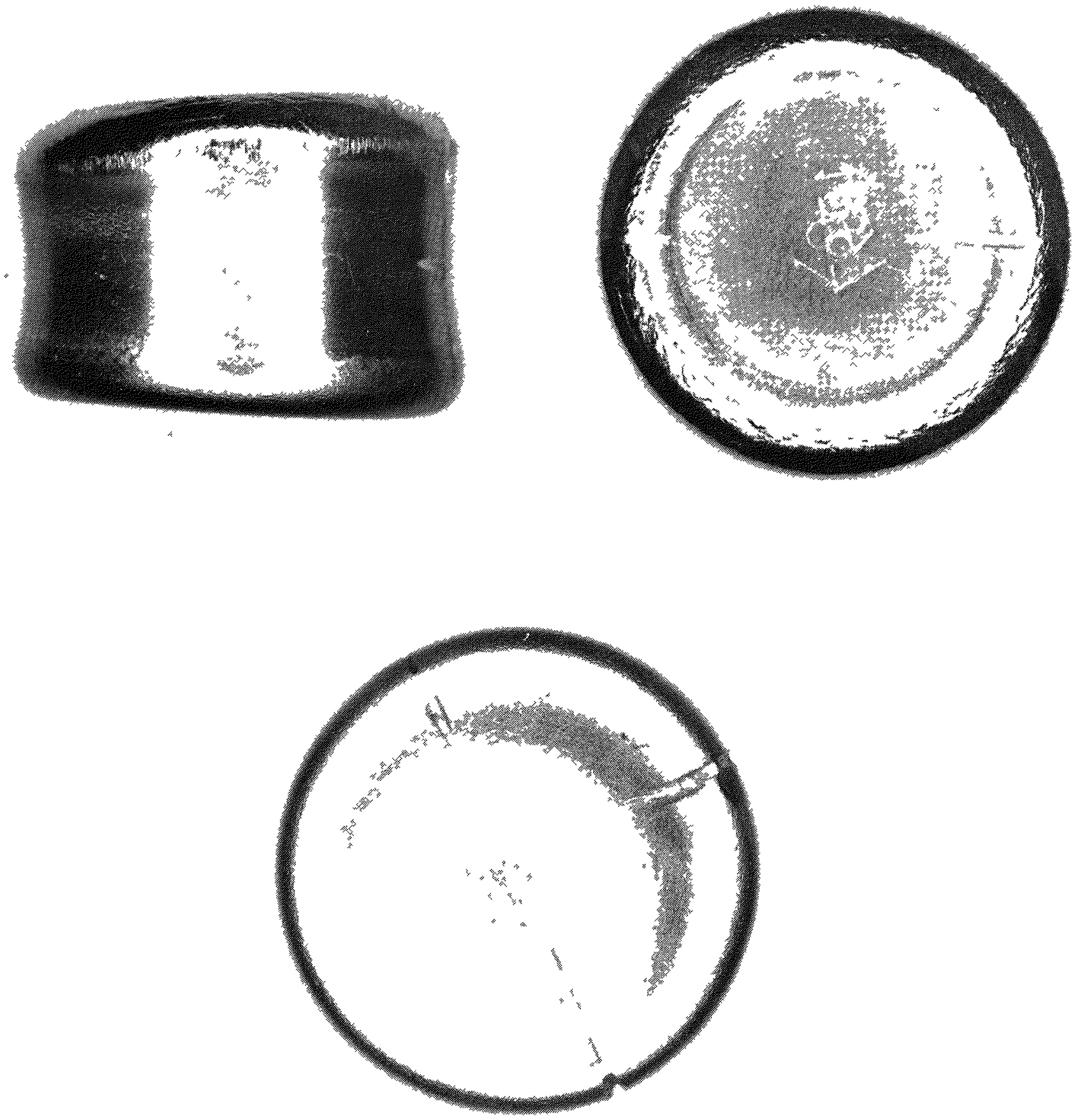

FIGURE 105 - WMT-18 strength member. Note the laser marking of the strength member cap \#1884, and the mirror image of the number of the clad cap \#1797 Impressed into the strength member cap as a result of the impact. 

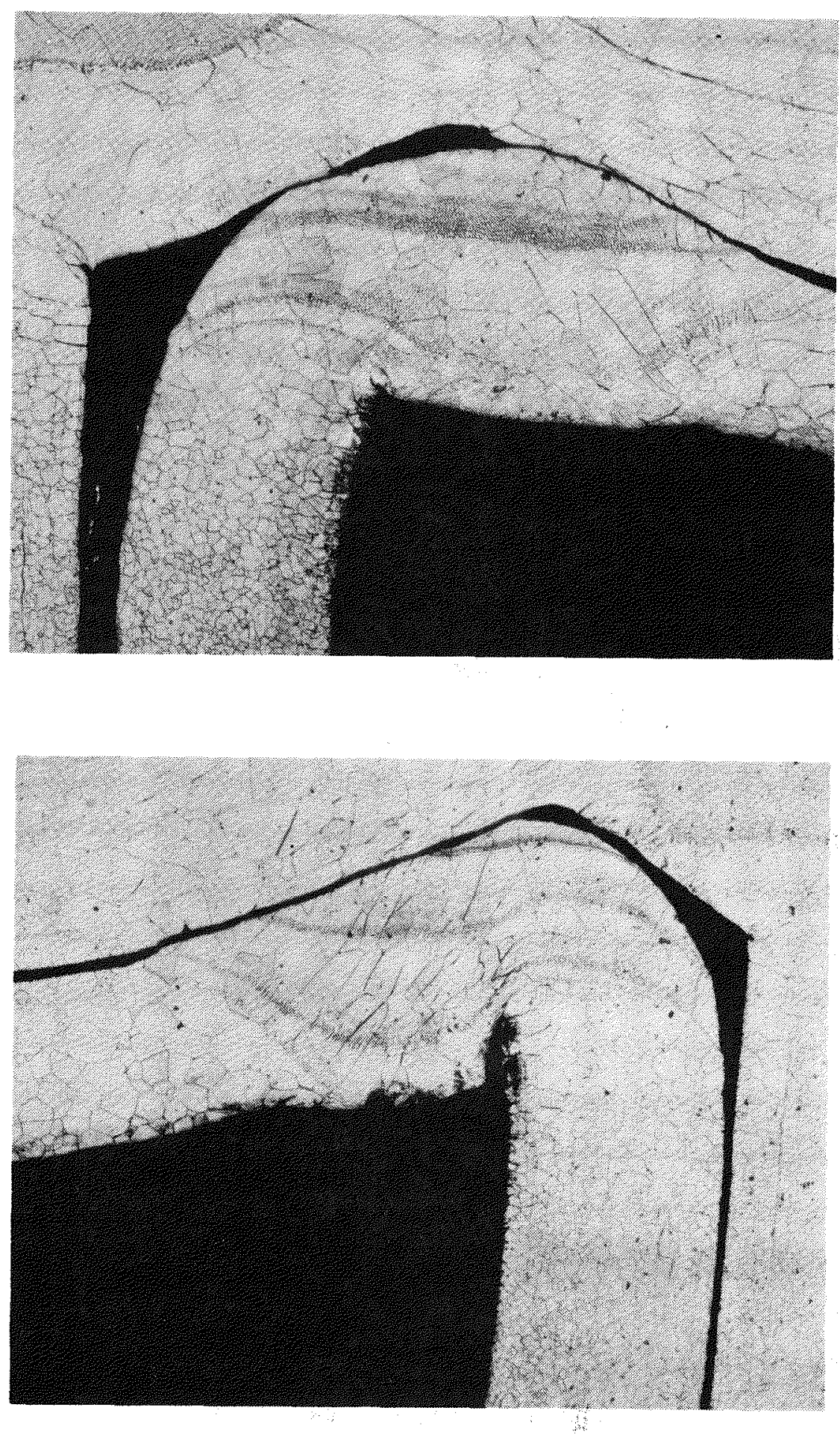

FIGURE 106 - WMT-18 cross section of liner weld. (50X) 

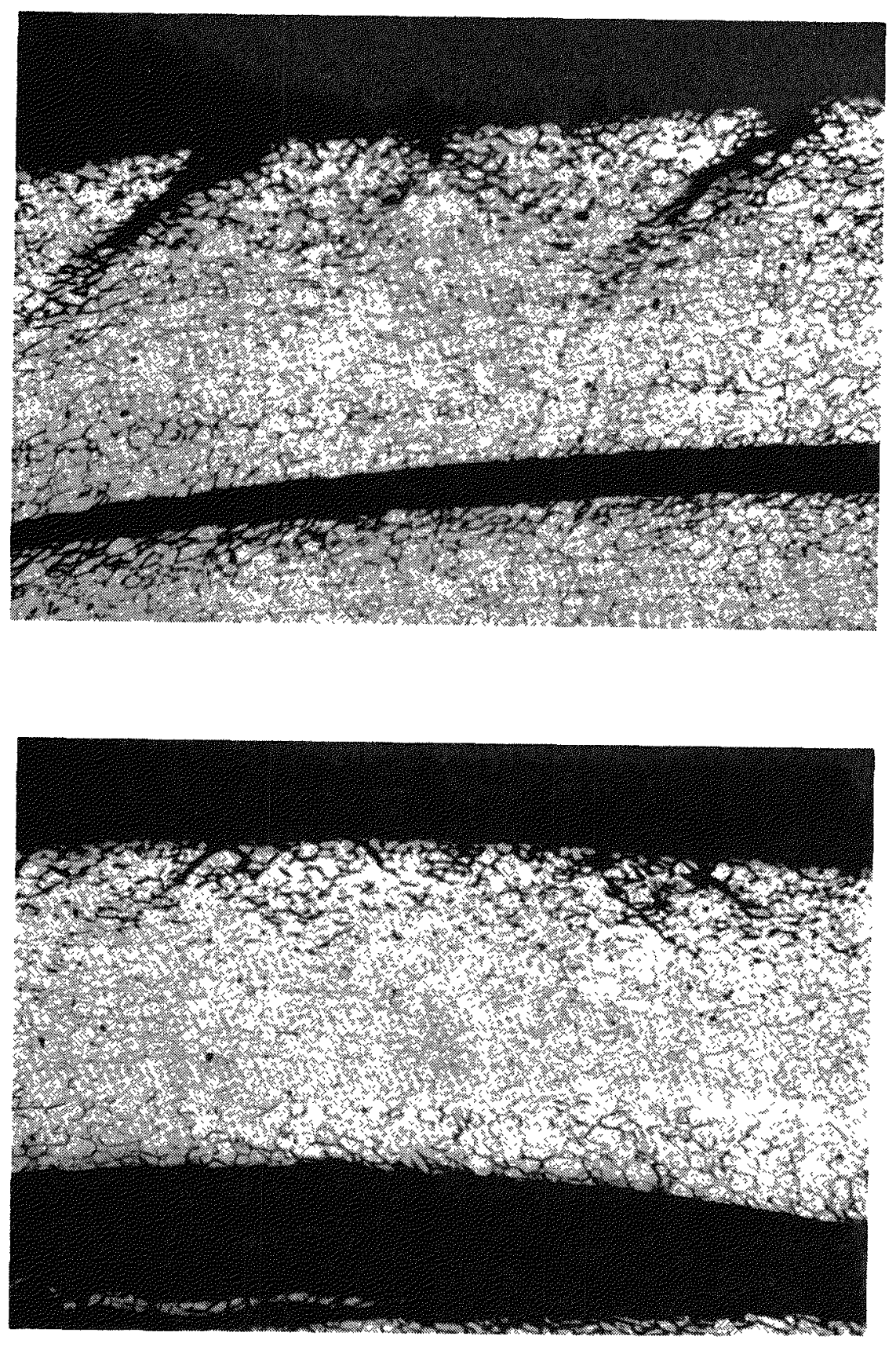

FIGURE 107 - WMT-18 cross section of liner, dome end. (100X) 

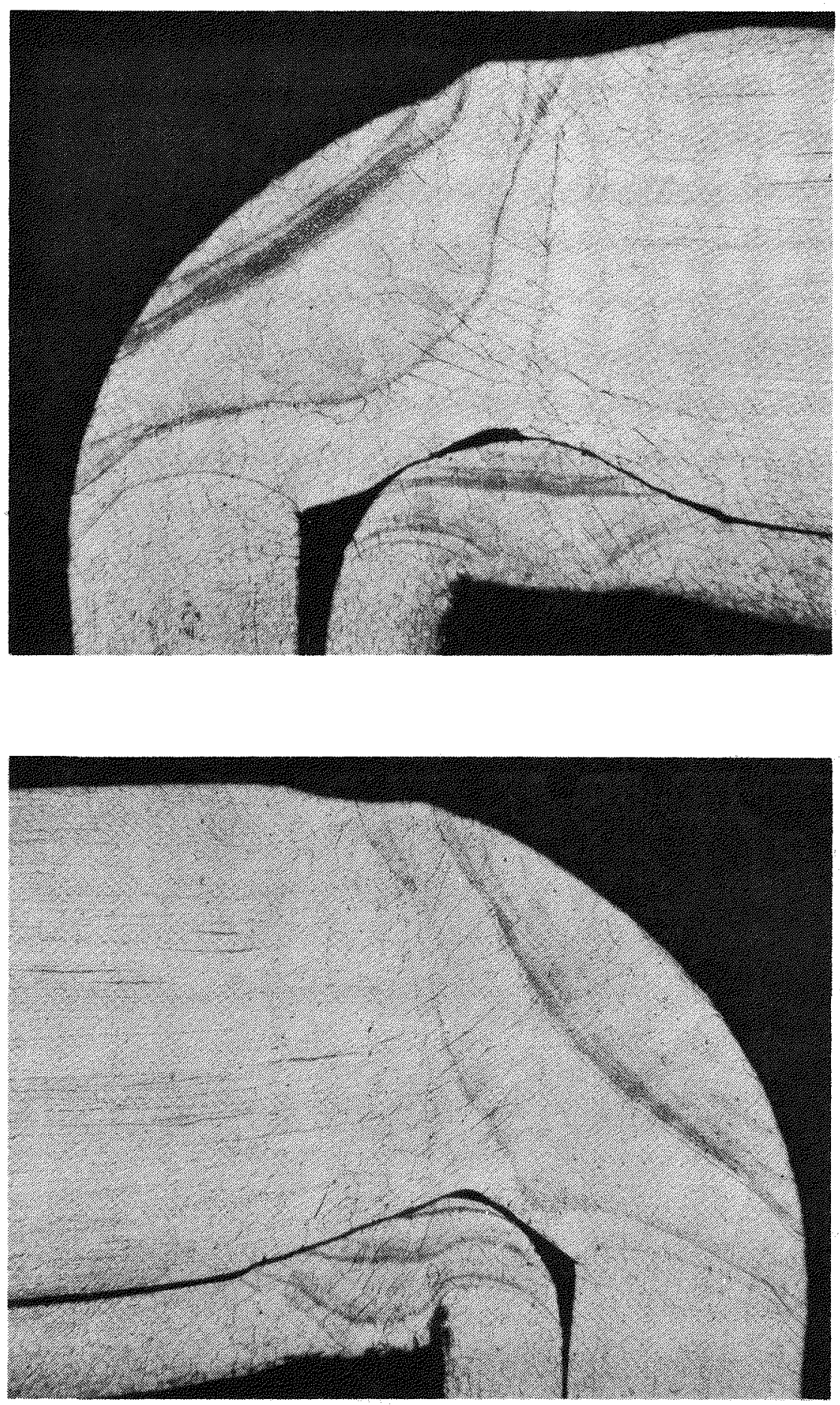

FIGURE 108 - WMT-18 cross section of liner and strength member welds. (27.5X) 

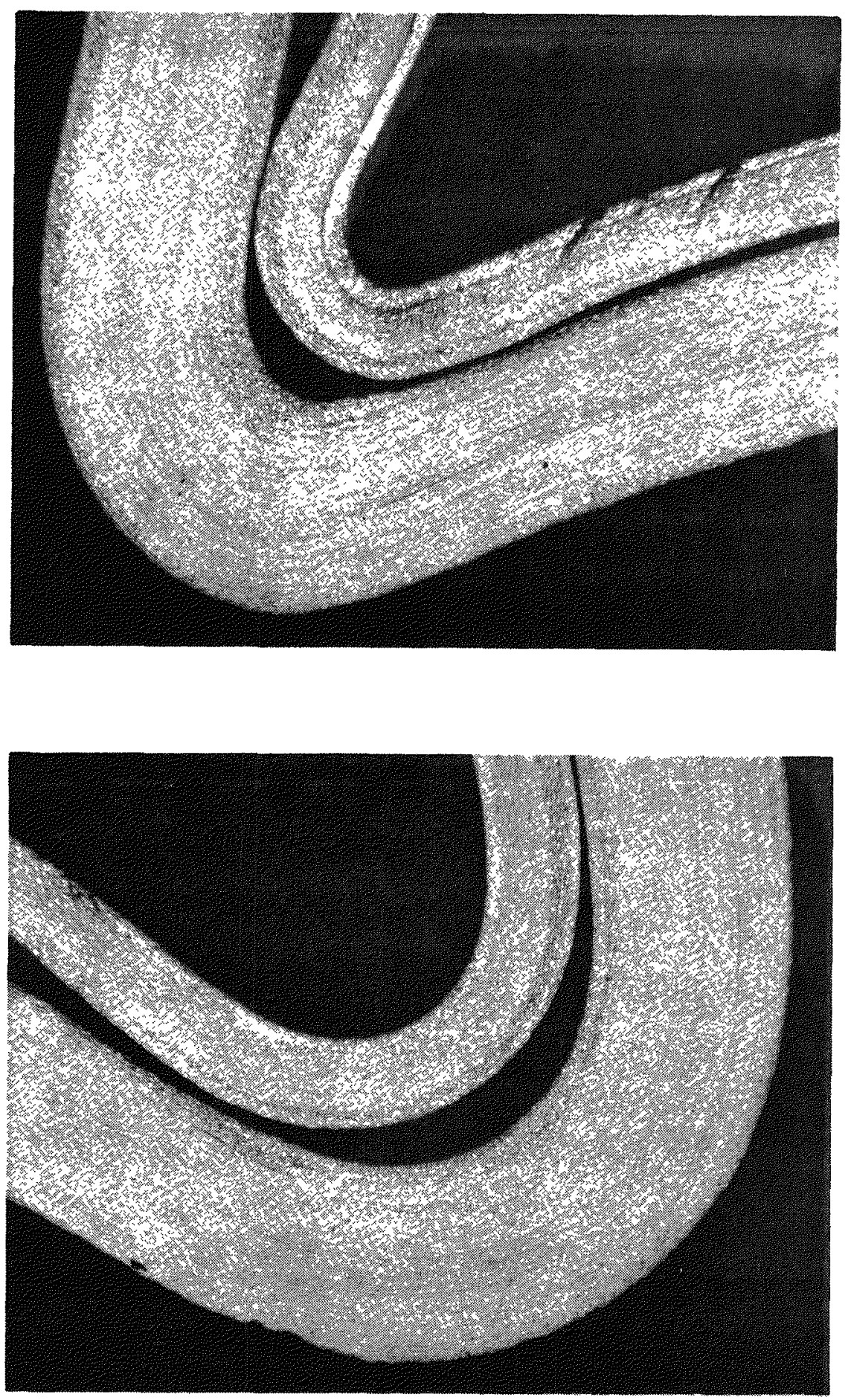

FIGURE 109 - WMT-18 cross section of liner and strength member through dome end. (27.5X) 


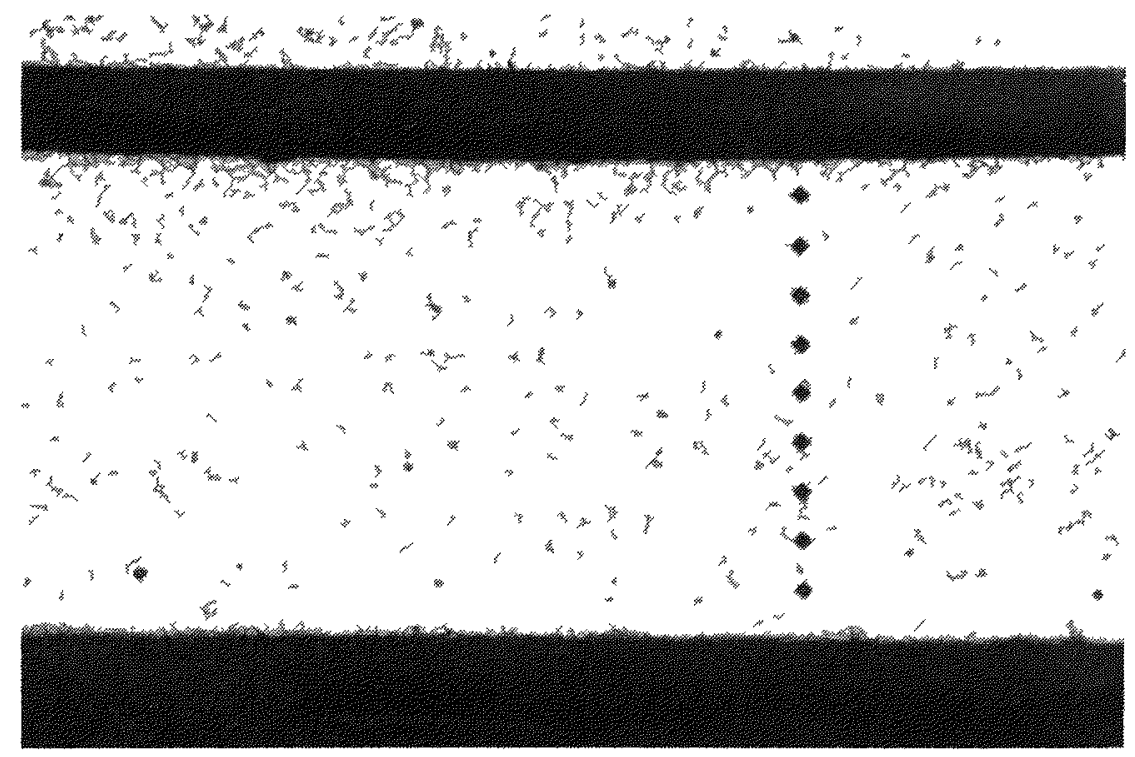

FIGURE 110 - WMT-18 lıner cap. (100X) 


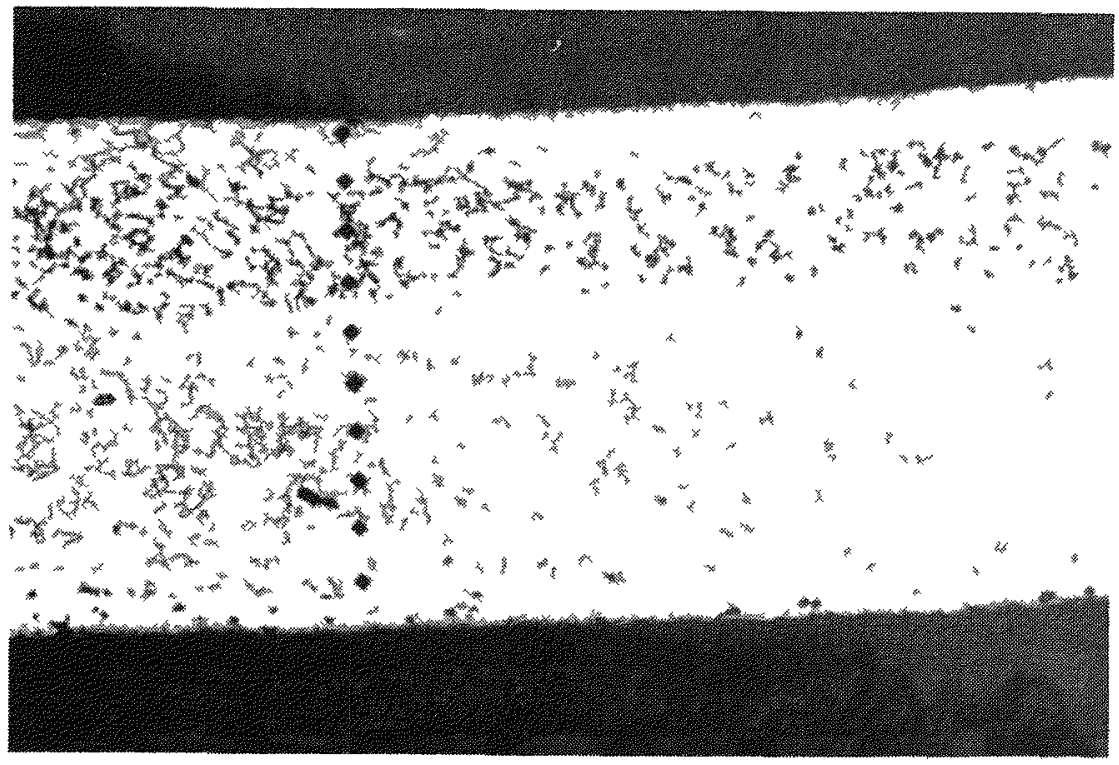

FIGURE 111 - WMT-18 liner side wall. (100X) 

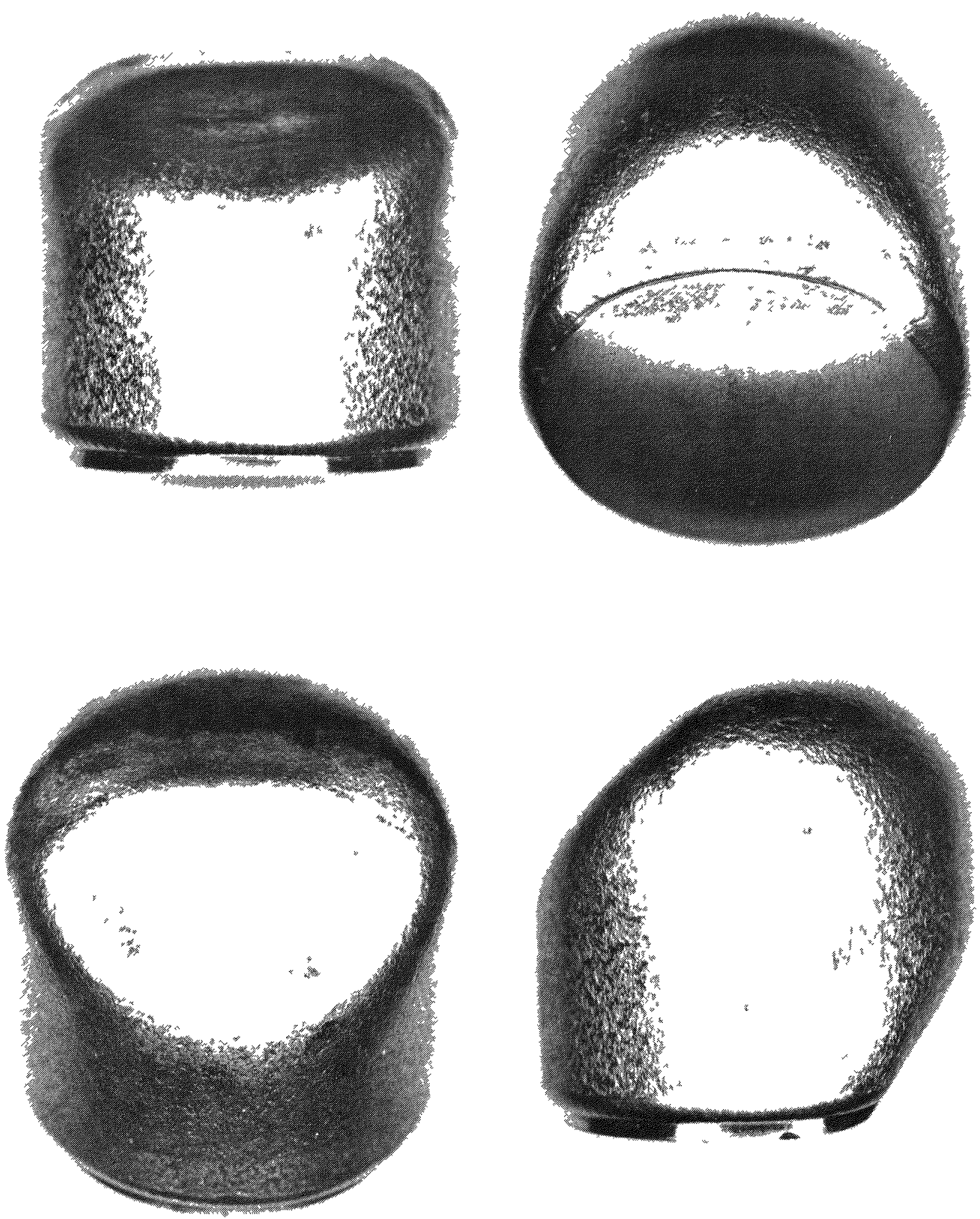

FIGURE 112 - WMT-31 after the dome corner was impacted at $83.0 \mathrm{~m} / \mathrm{sec}$ and the cap corner at $81.8 \mathrm{~m} / \mathrm{sec}$. 

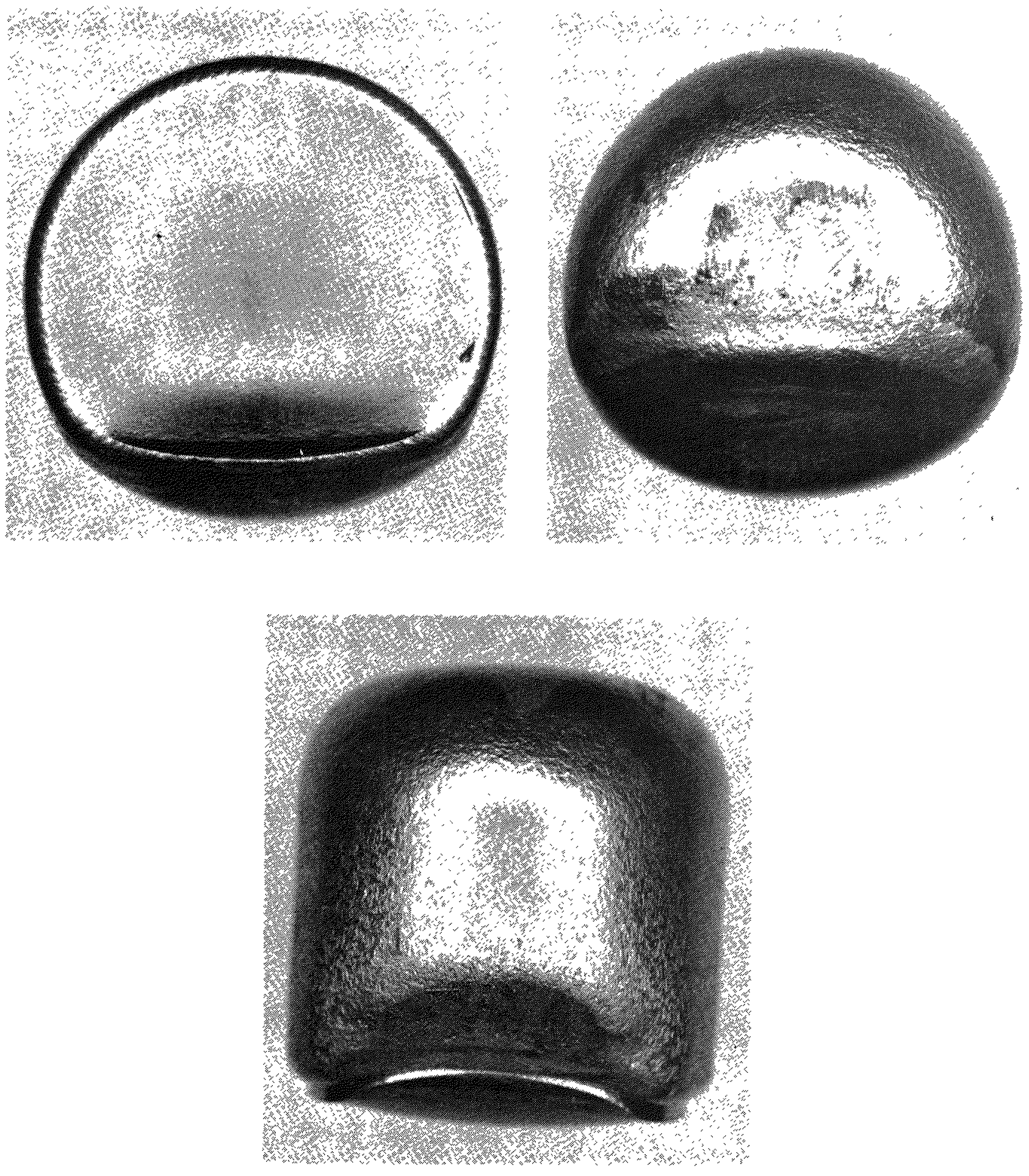

FIGURE 113 - WMT-31 clad after second impact. 

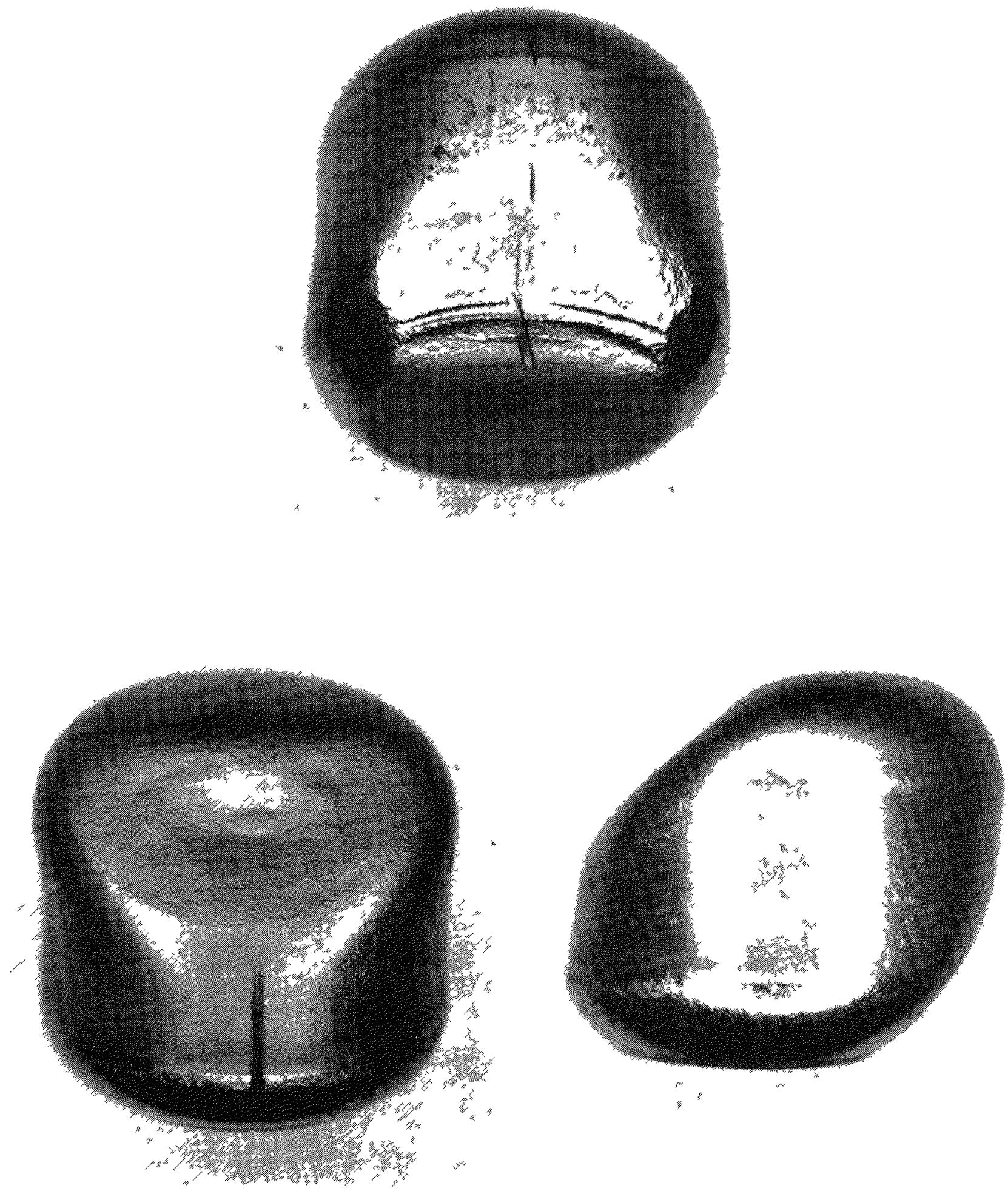

FIGURE 114 - WMT-31 strength member showing side view impact face on corner of dome end and impact face on corner of cap 


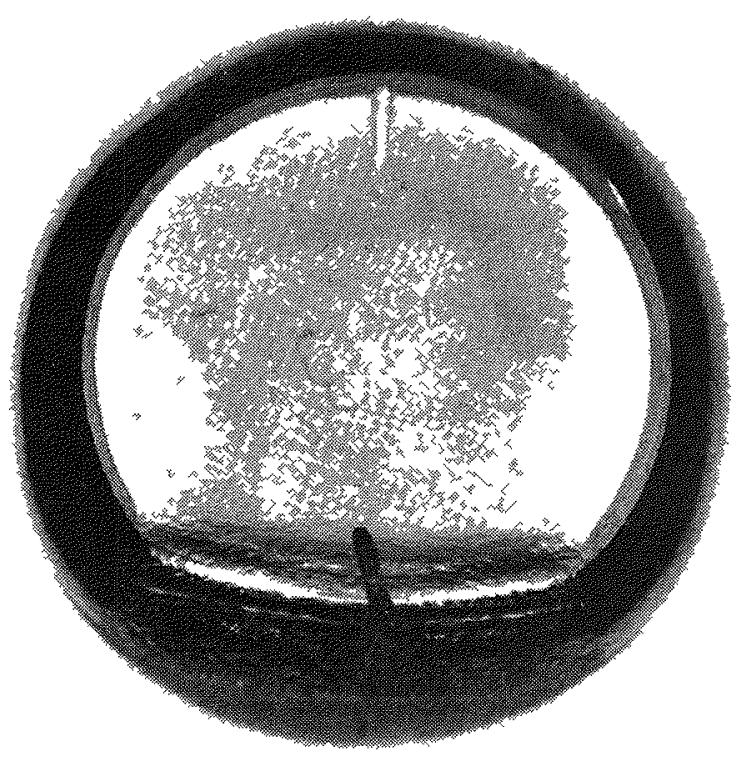

FIGURE 115 - WMT-31 strength member cap.

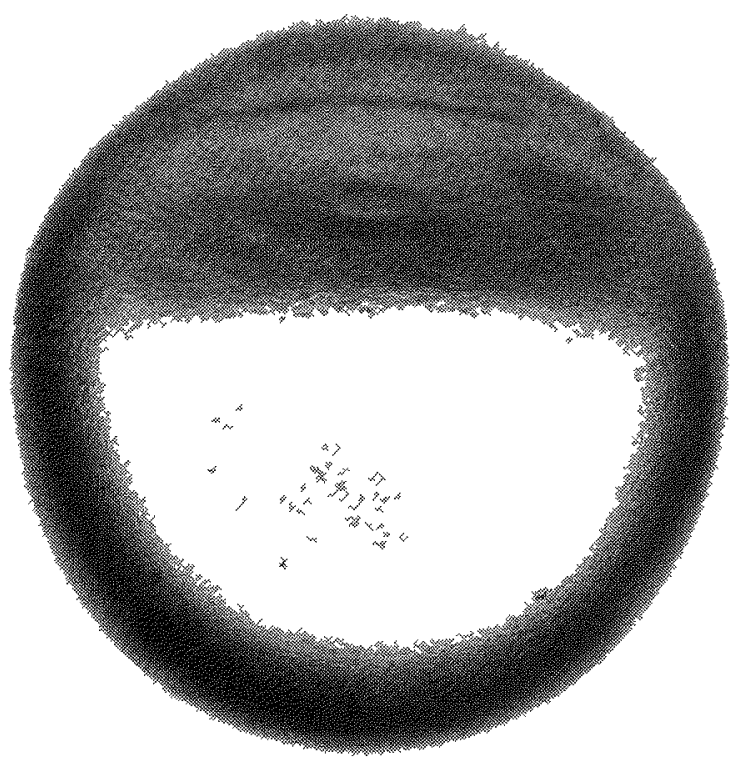

FIGURE 116 - WMT-31 strength member dome. 


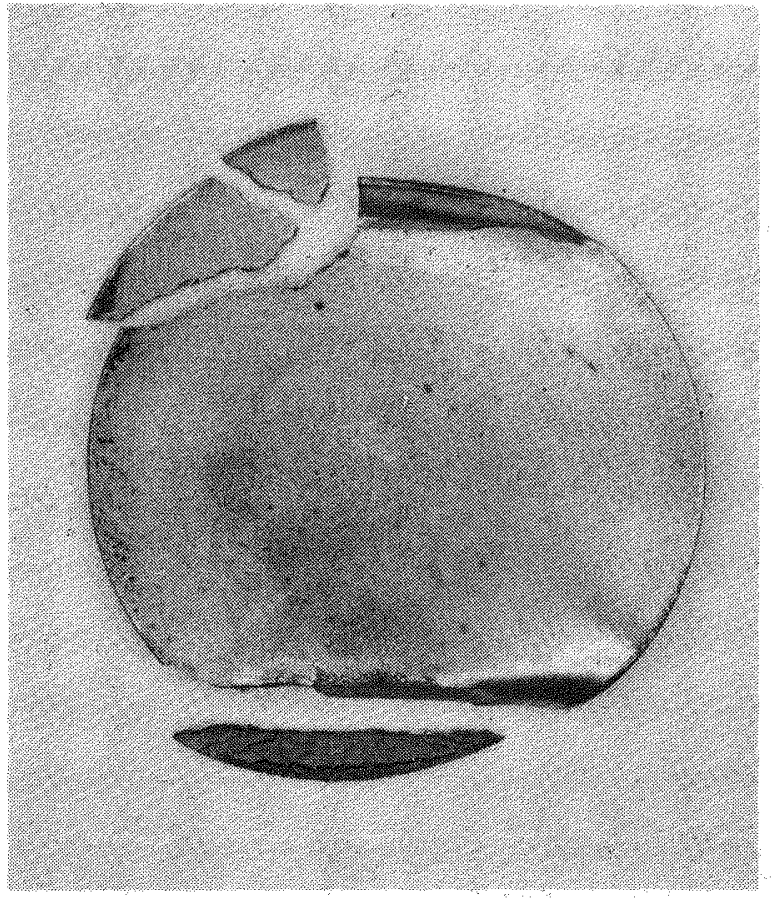

FIGURE 117 - WMT-31 shim as removed from capsule after impact. 

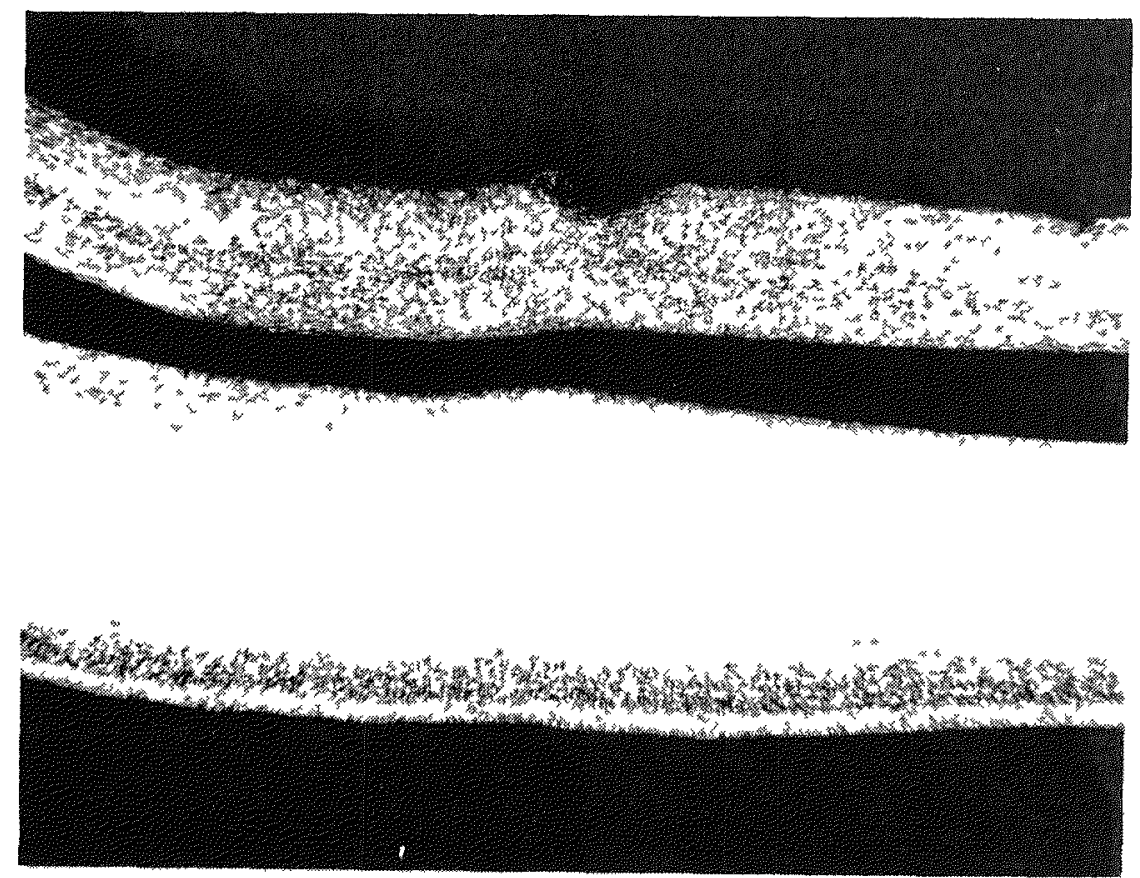

FIGURE 118 - WMT-31 liner and strength member side wall showing dent where shim cut into liner (27.5X) 


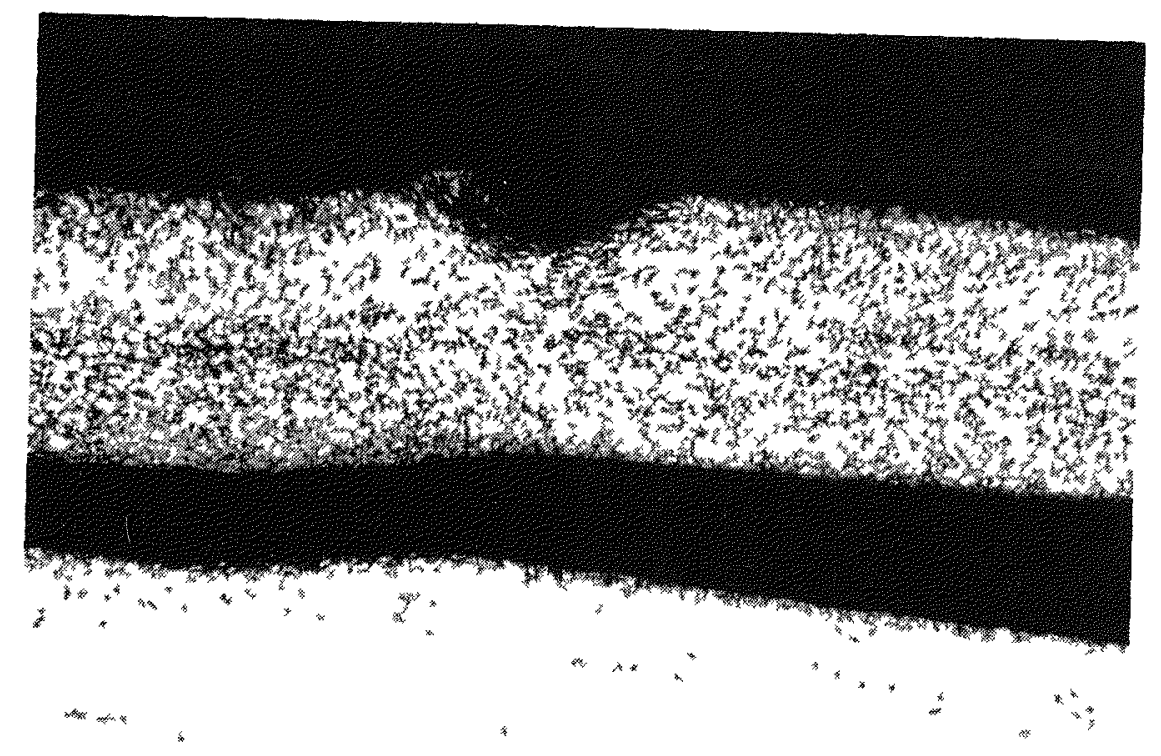

FIGURE 119 - WMT-31 liner side wall showing area where shım cut into liner (50X) 


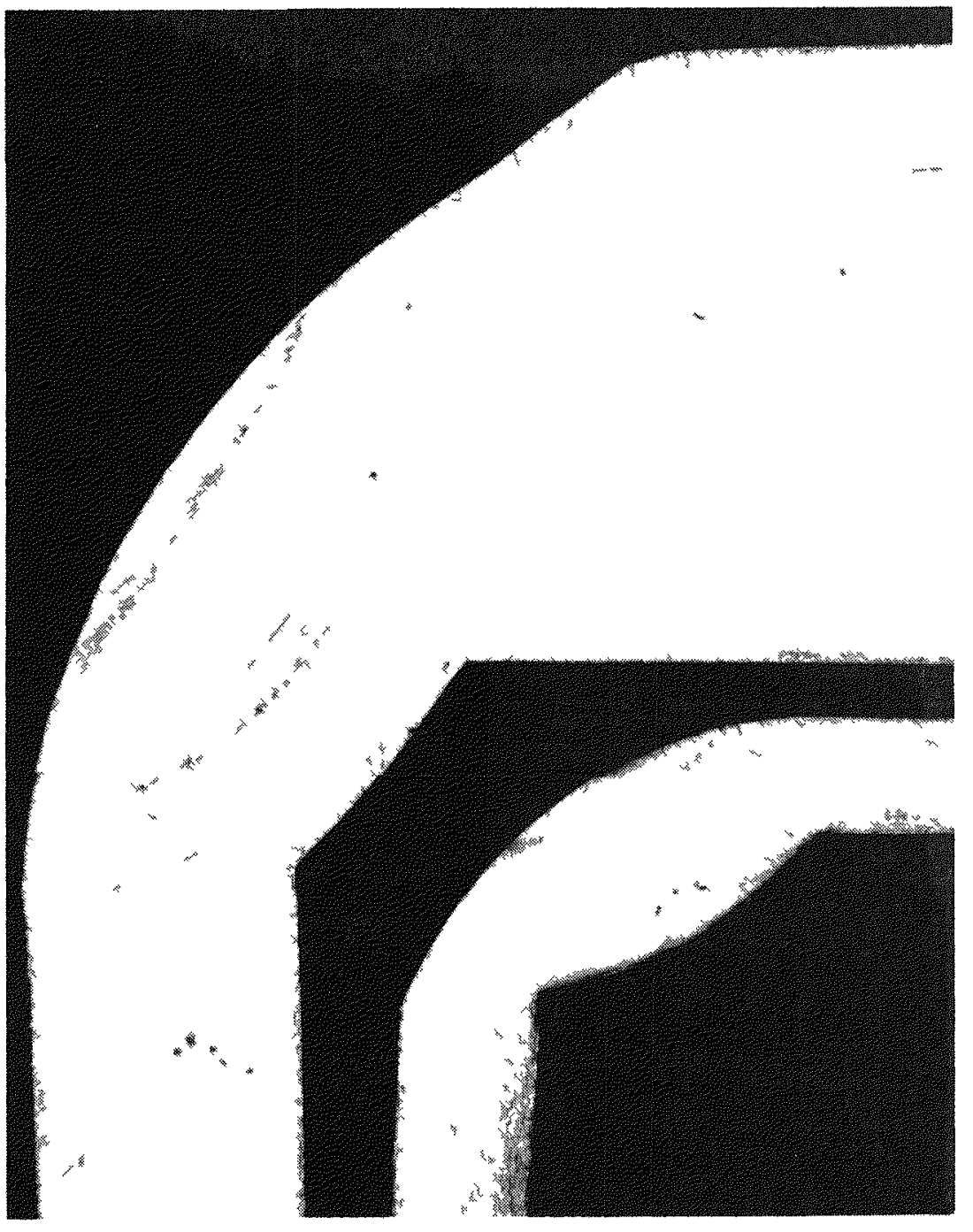

FIGURE 120 - WMT-31 cross section of liner and strength member welds at $180^{\circ}$ of impact (27 5X) 


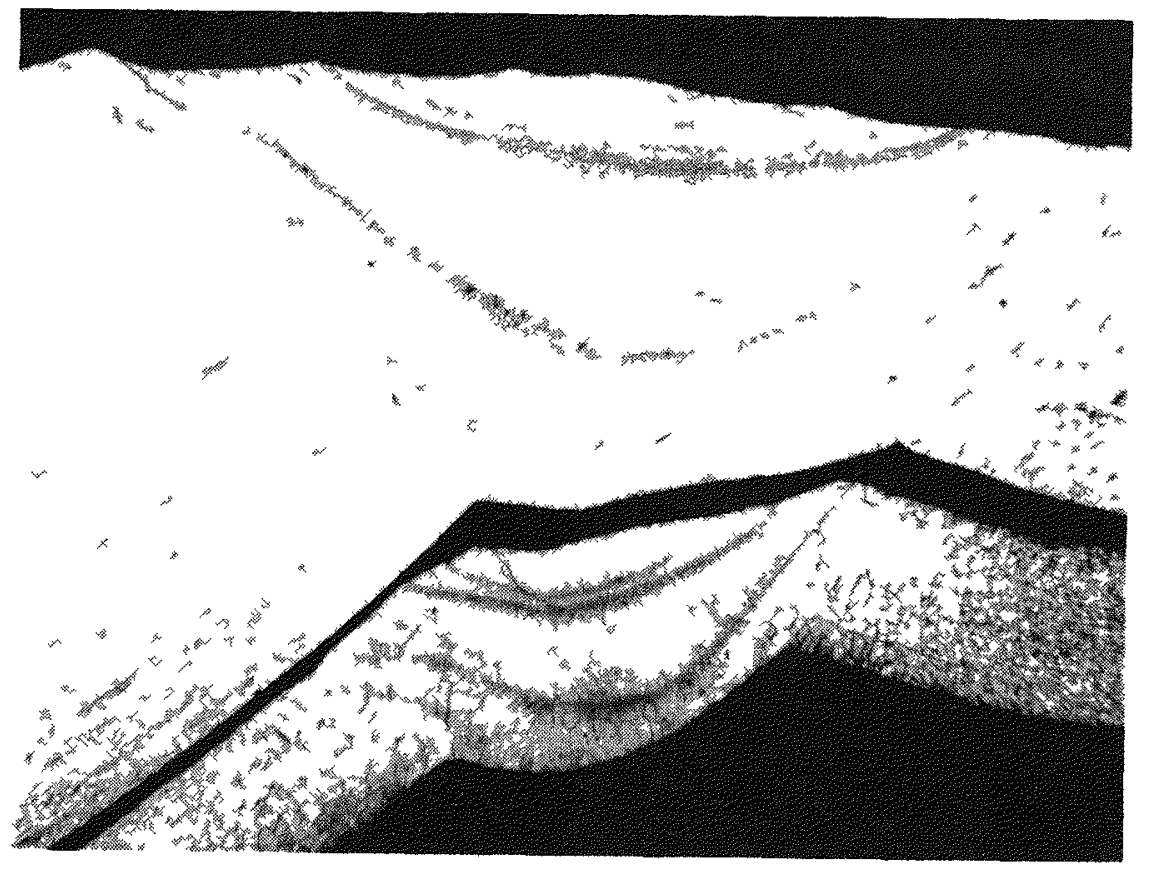

FIGURE 121 - WMT-31 cross section of liner and strength member welds through impact face (27 5X) 


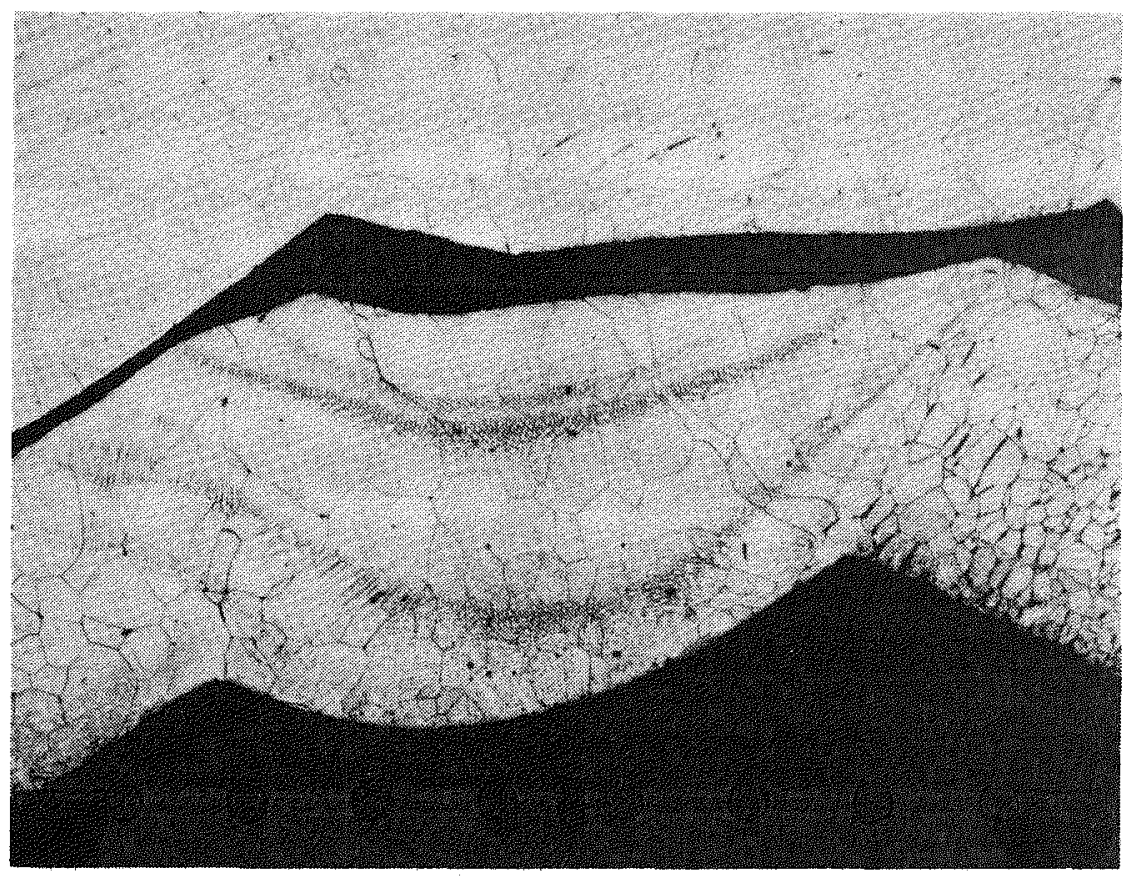

FIGURE 122 - WMT-31 cross section of liner weld through impact face. (50X) 


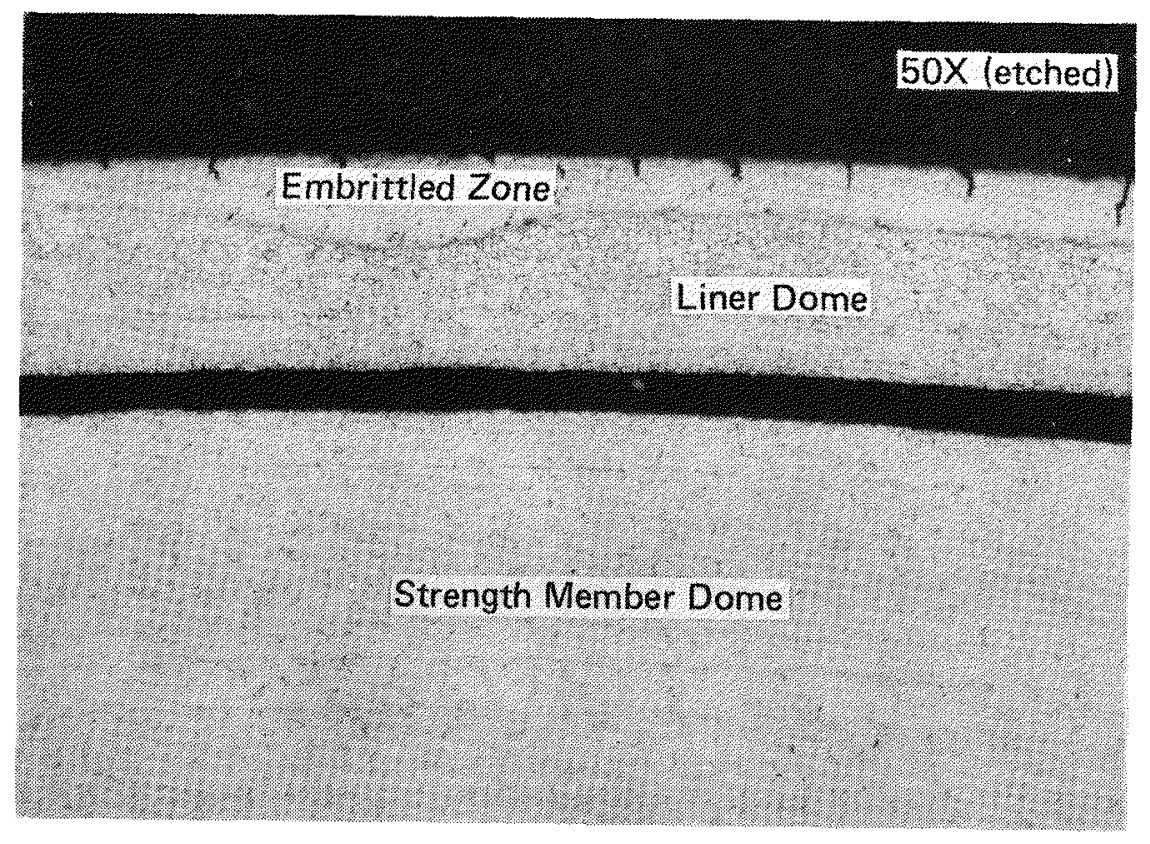

FIGURE 123 - Cross-sectioned liner and strength member of WMT-17 show cracks along the inside edge of the liner. The microstructure is indicative of 3 to 7 mil deep T-111 embrittlement by oxygen. The microstructure was typical for WMT-10 through 18 and WMT-31. 
$\infty$

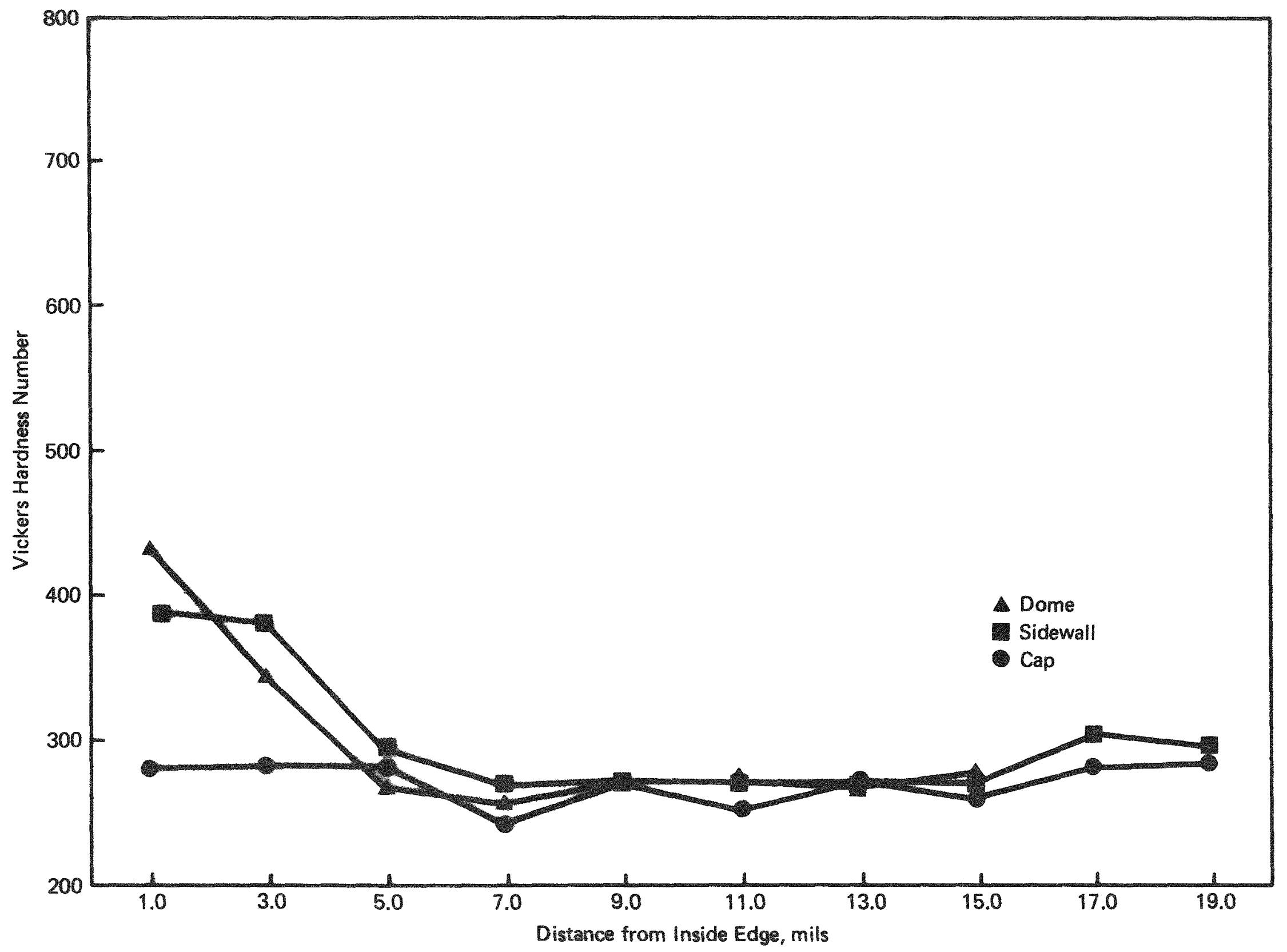

FIGURE 124 - Microhardness values for WMT-10 liner. 


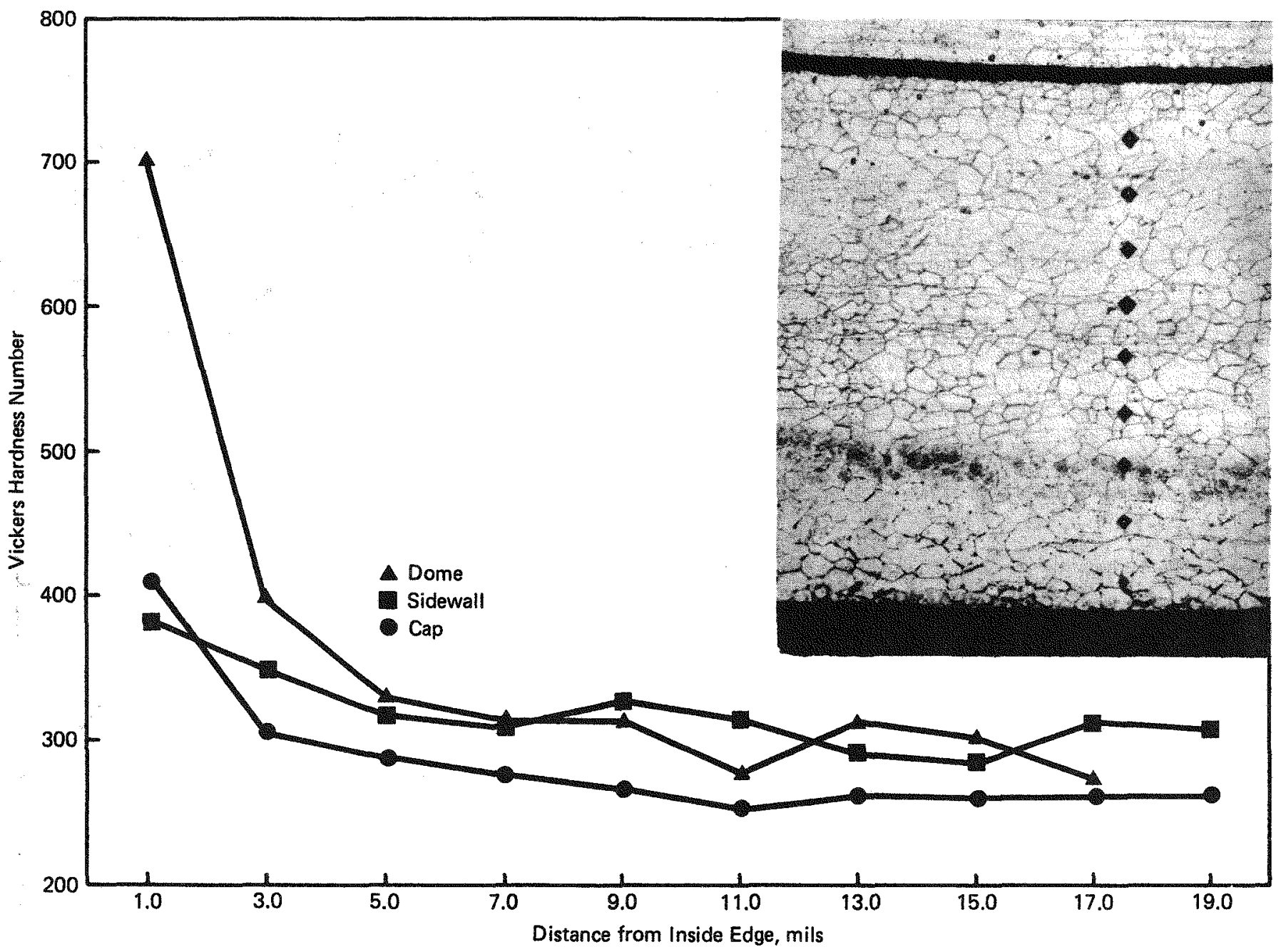


$\overrightarrow{8}$

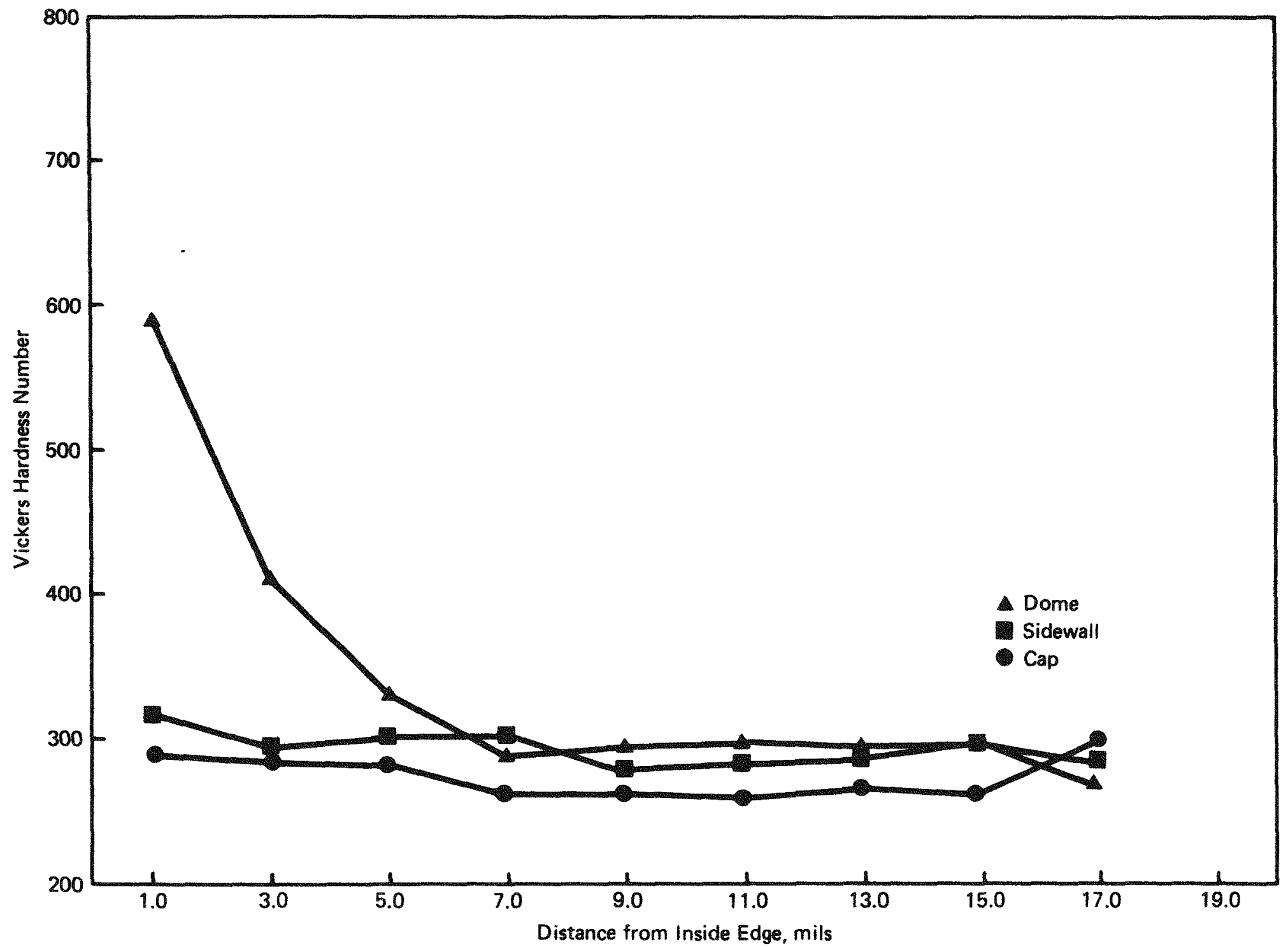

FIGURE 126 - Microhardness values for WMT-12 liner. 


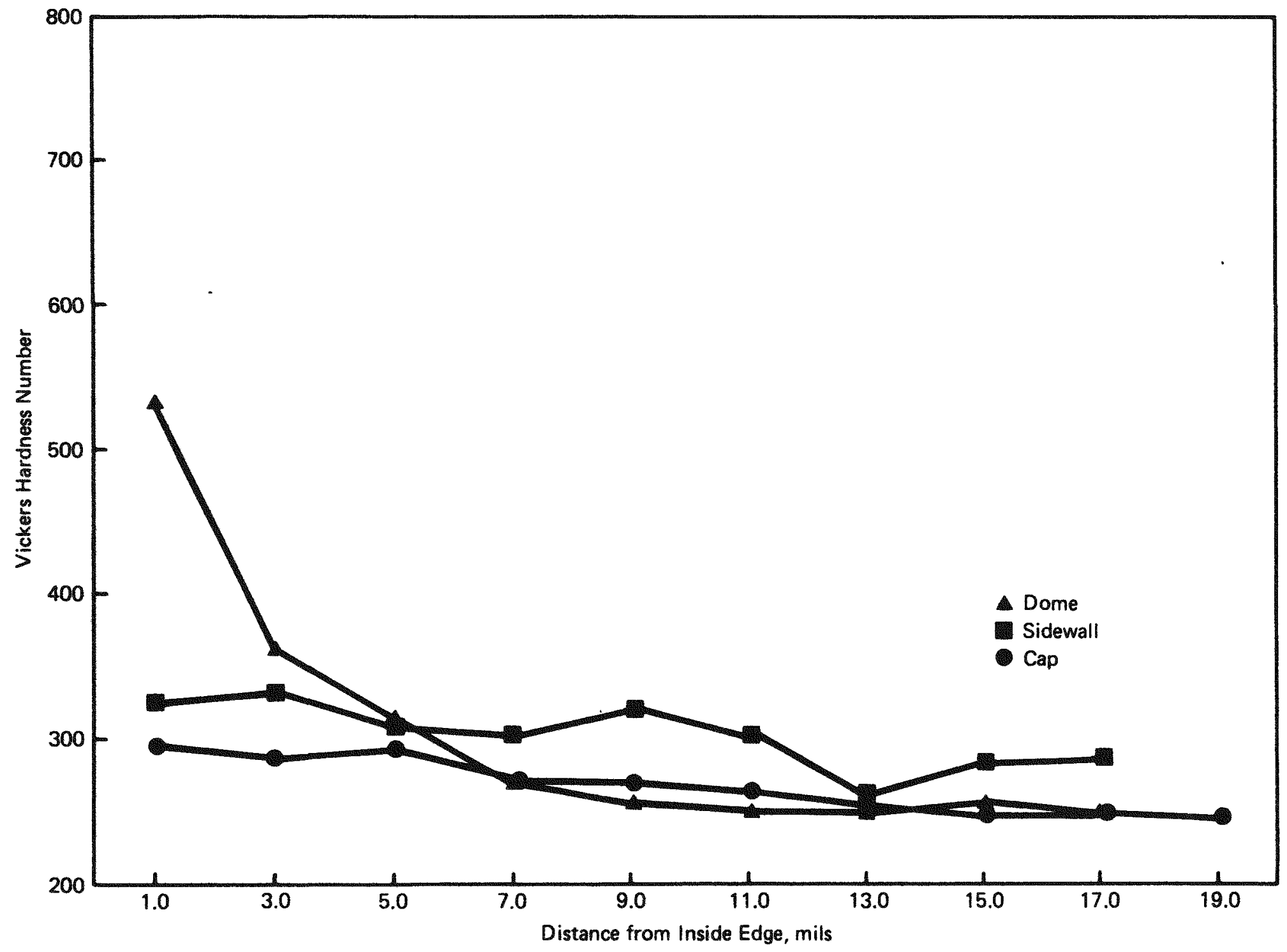

FICiURF 127 - Microhardness values for WMT-13 liner. 


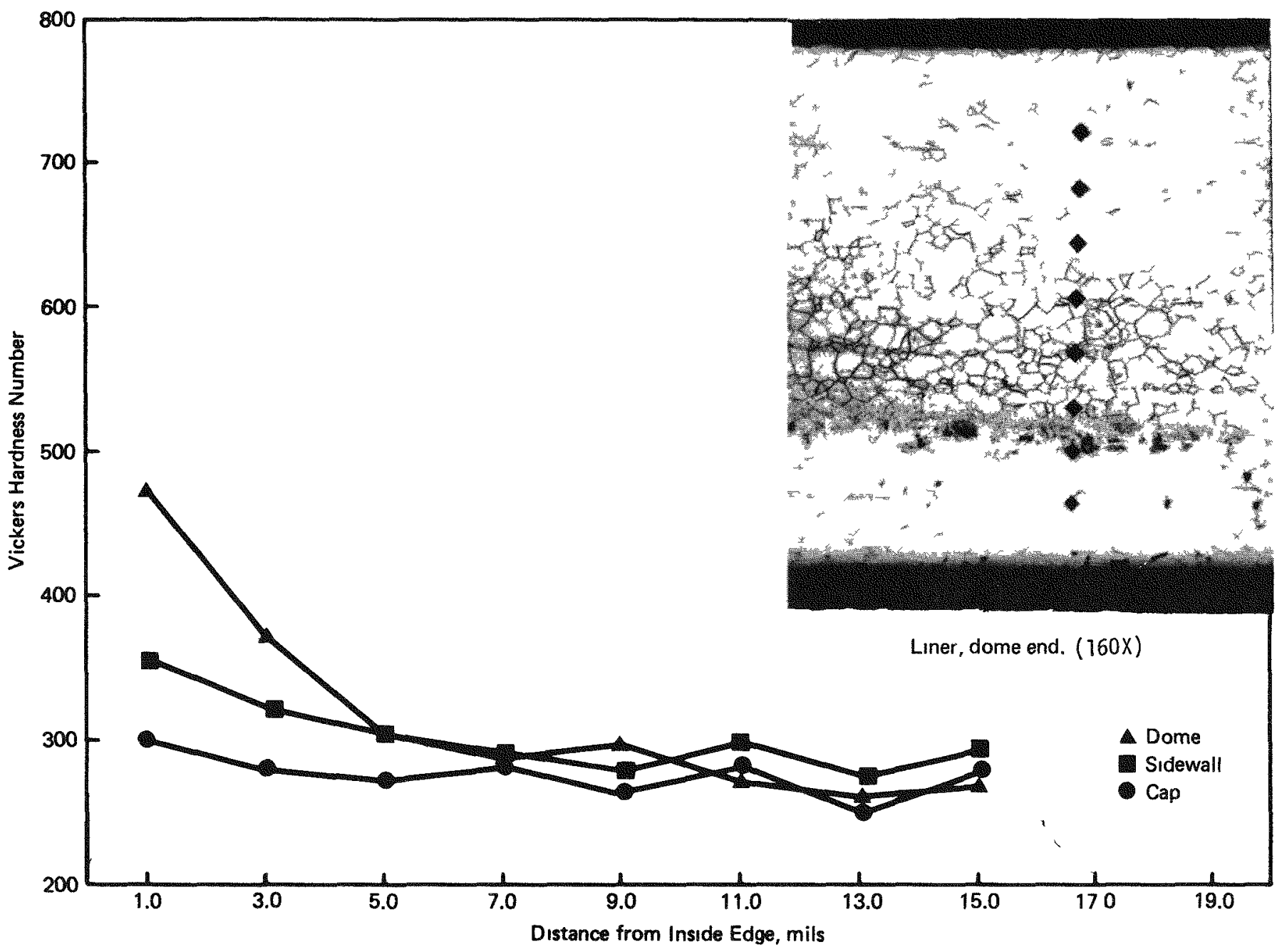

FIGURE 128 - Microhardness values for WMT-14 liner 


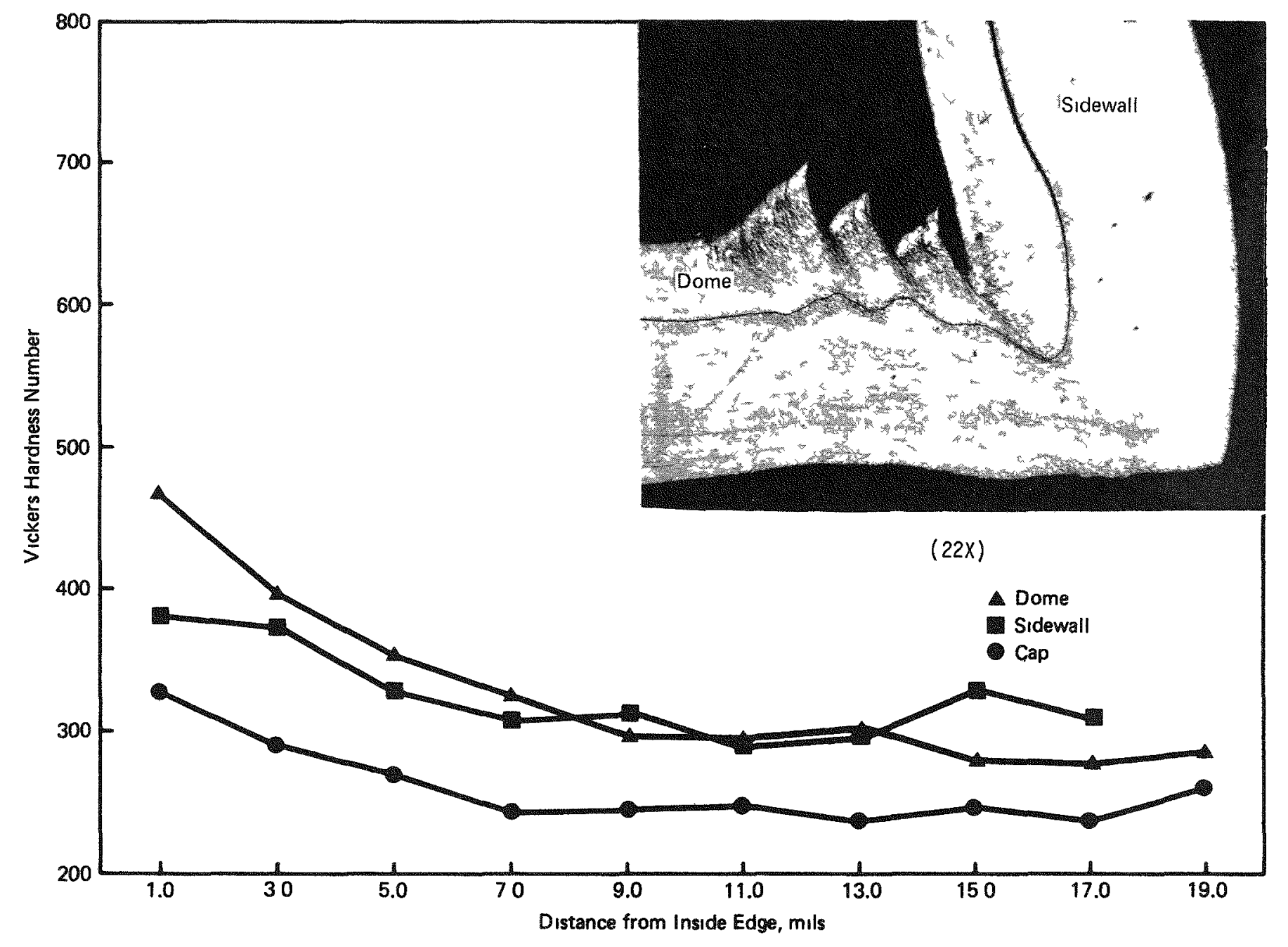




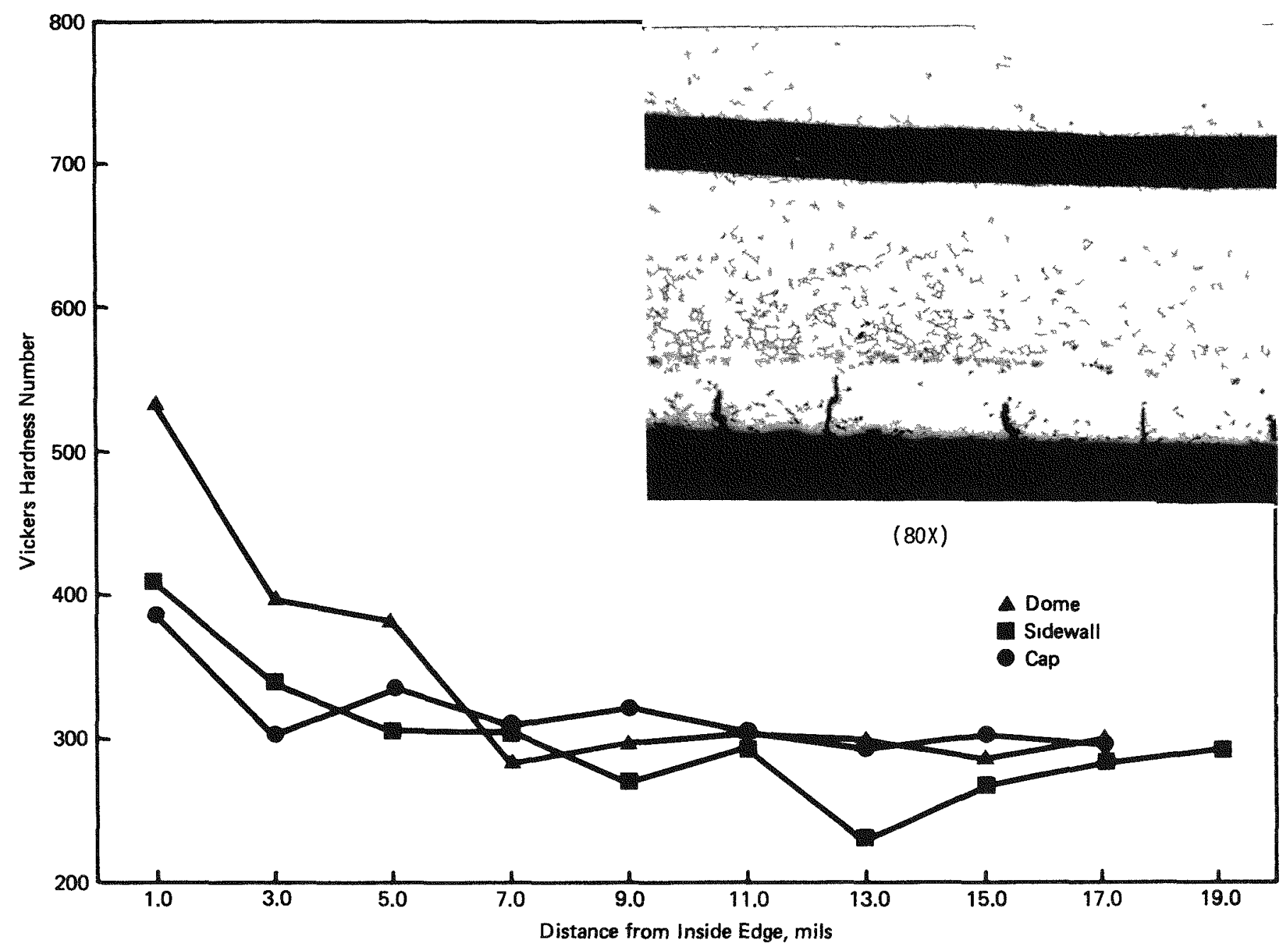

FIGURE 130 - Microhardness values for WMT-17 liner. 


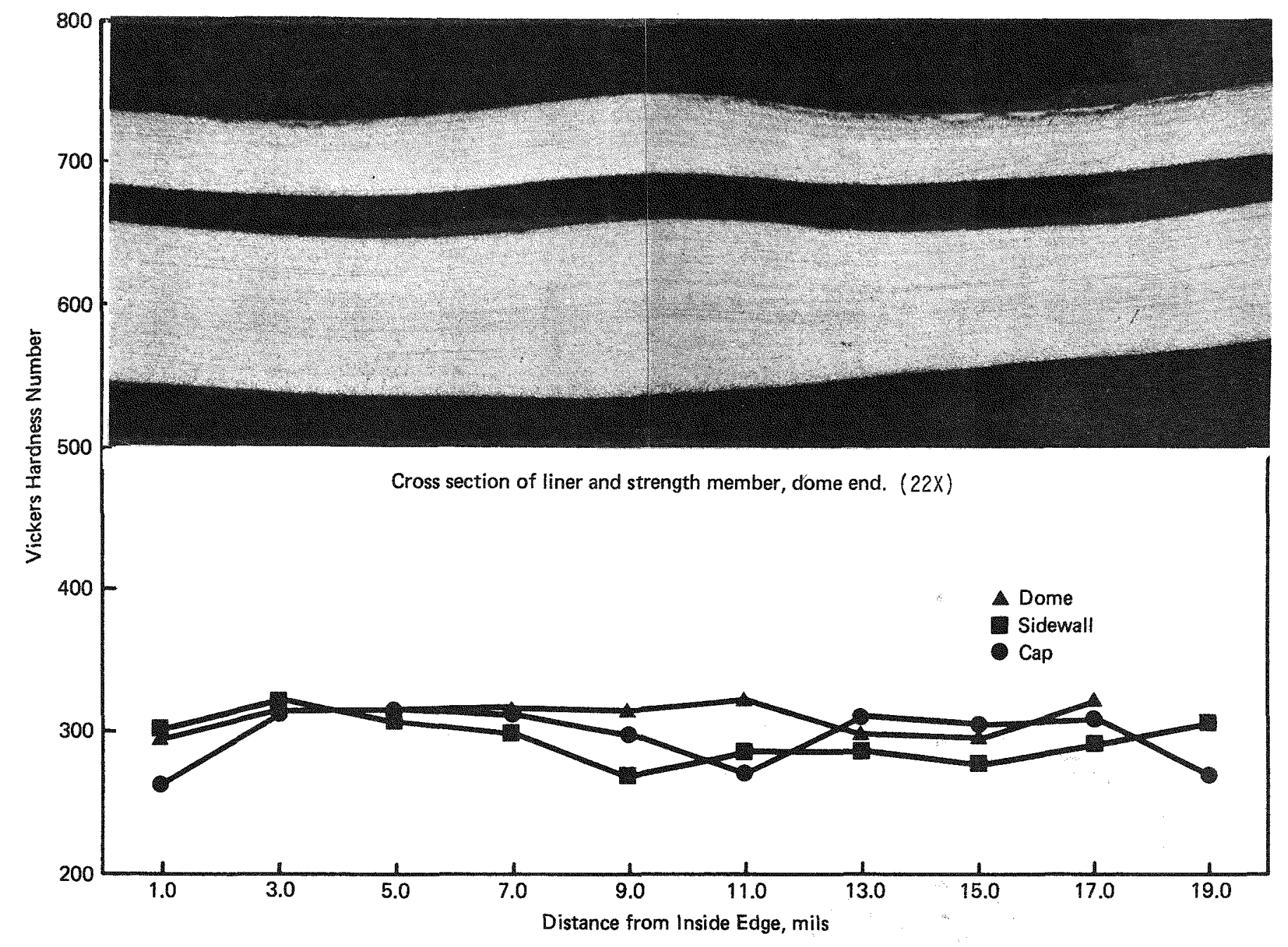




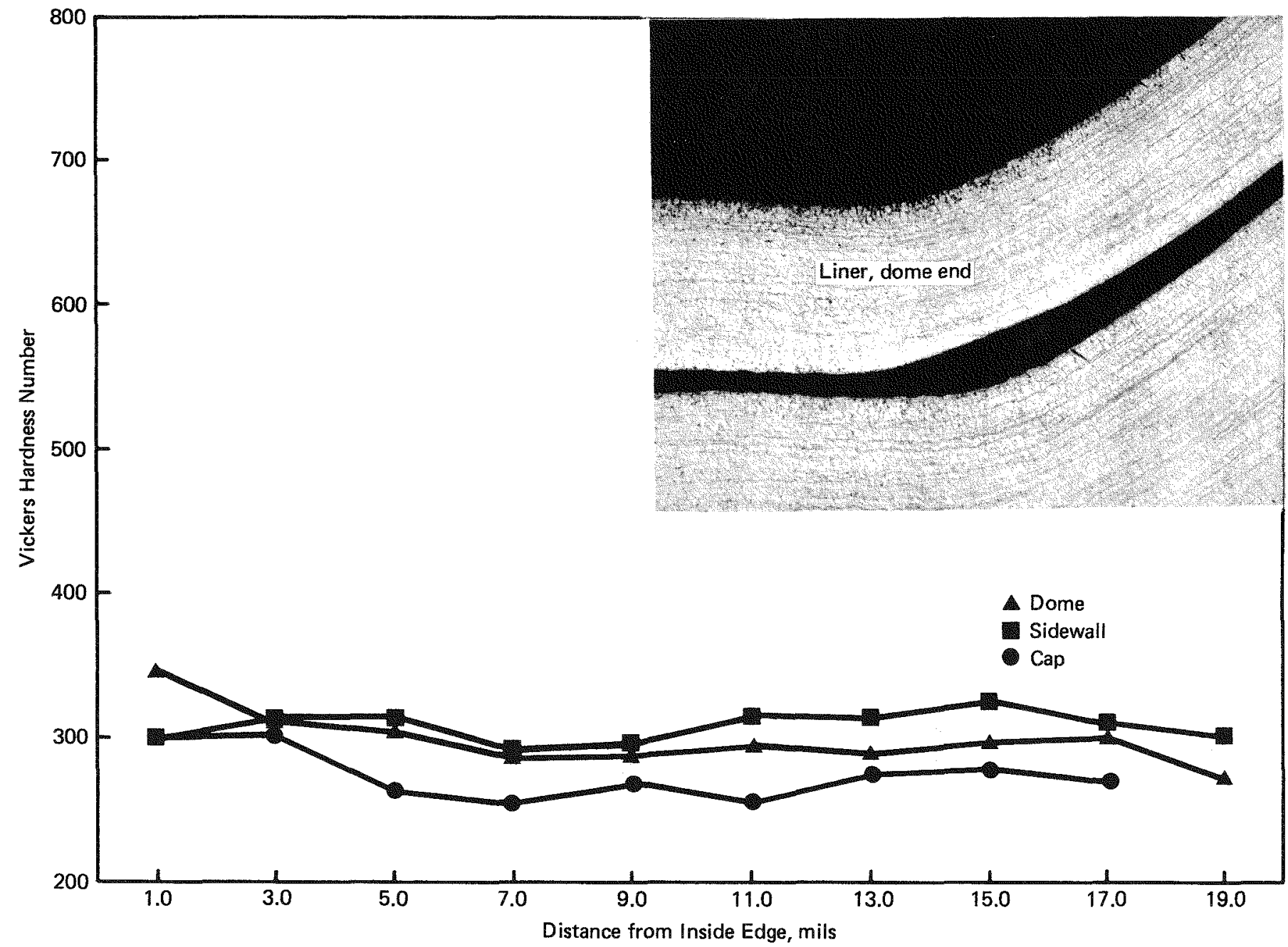

FIGURE 132 - Microhardness values for WMT-09 liner. 


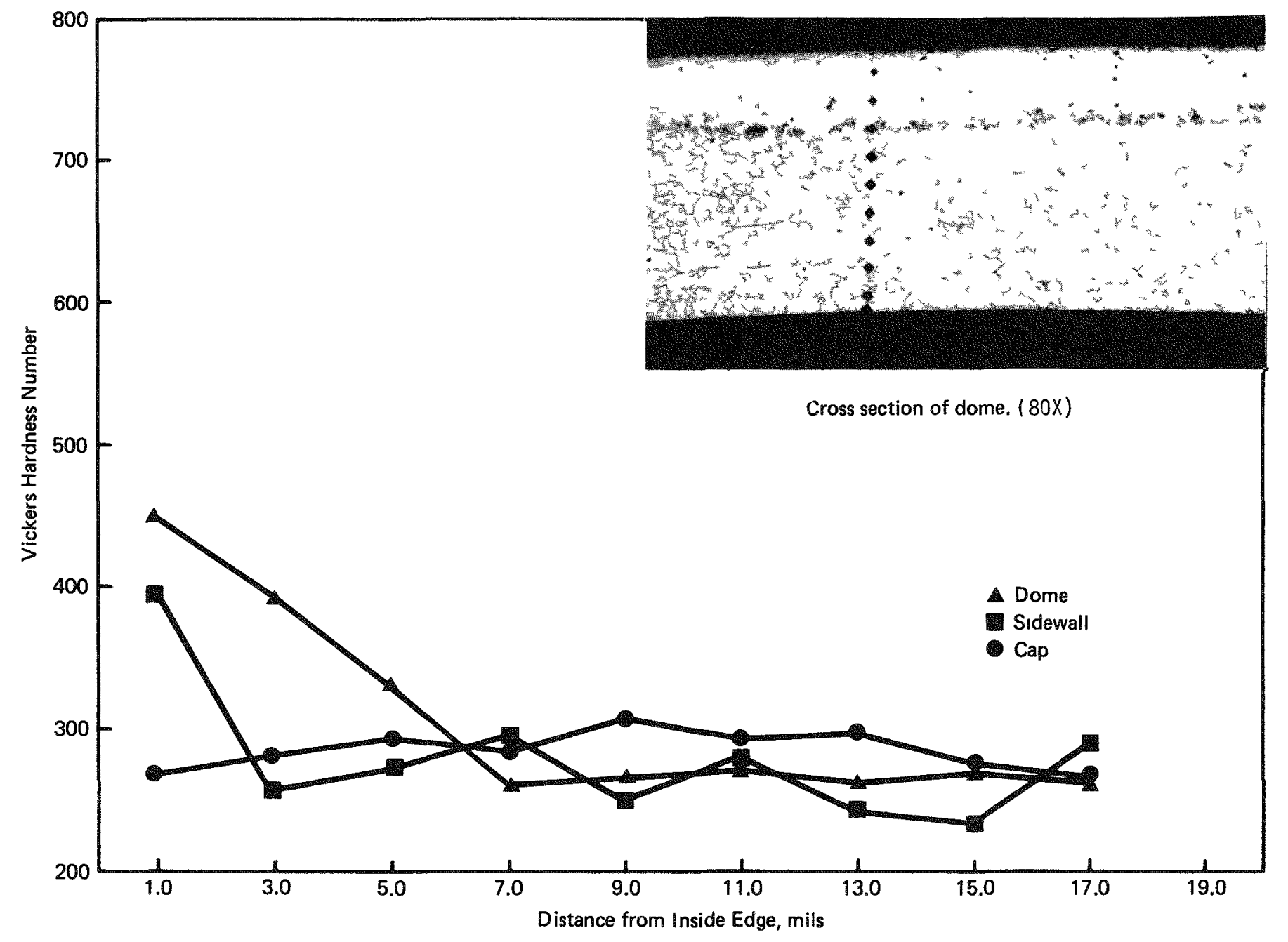




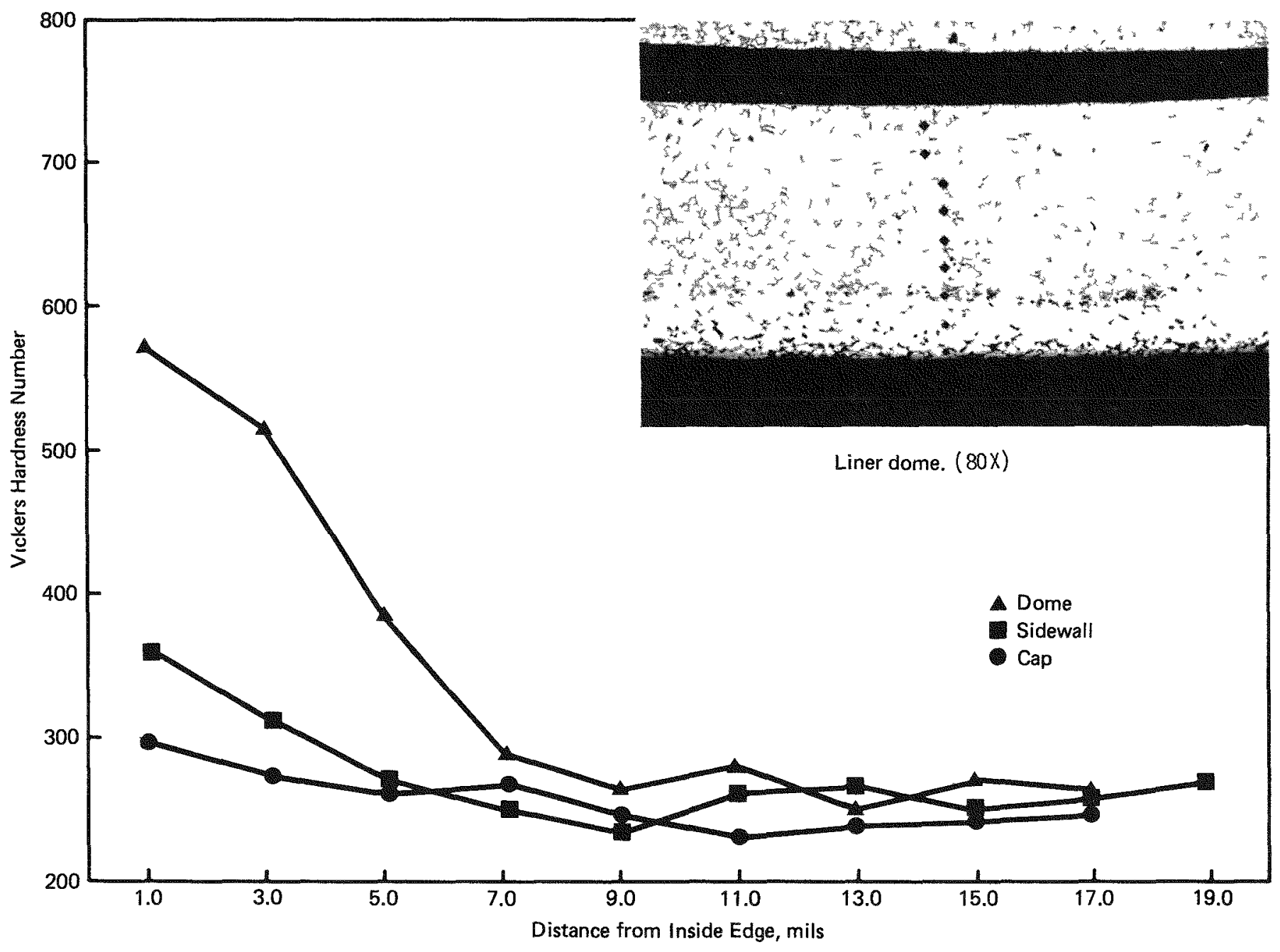

HGURF 134 - Mic rohardness values for WMT-18 liner 


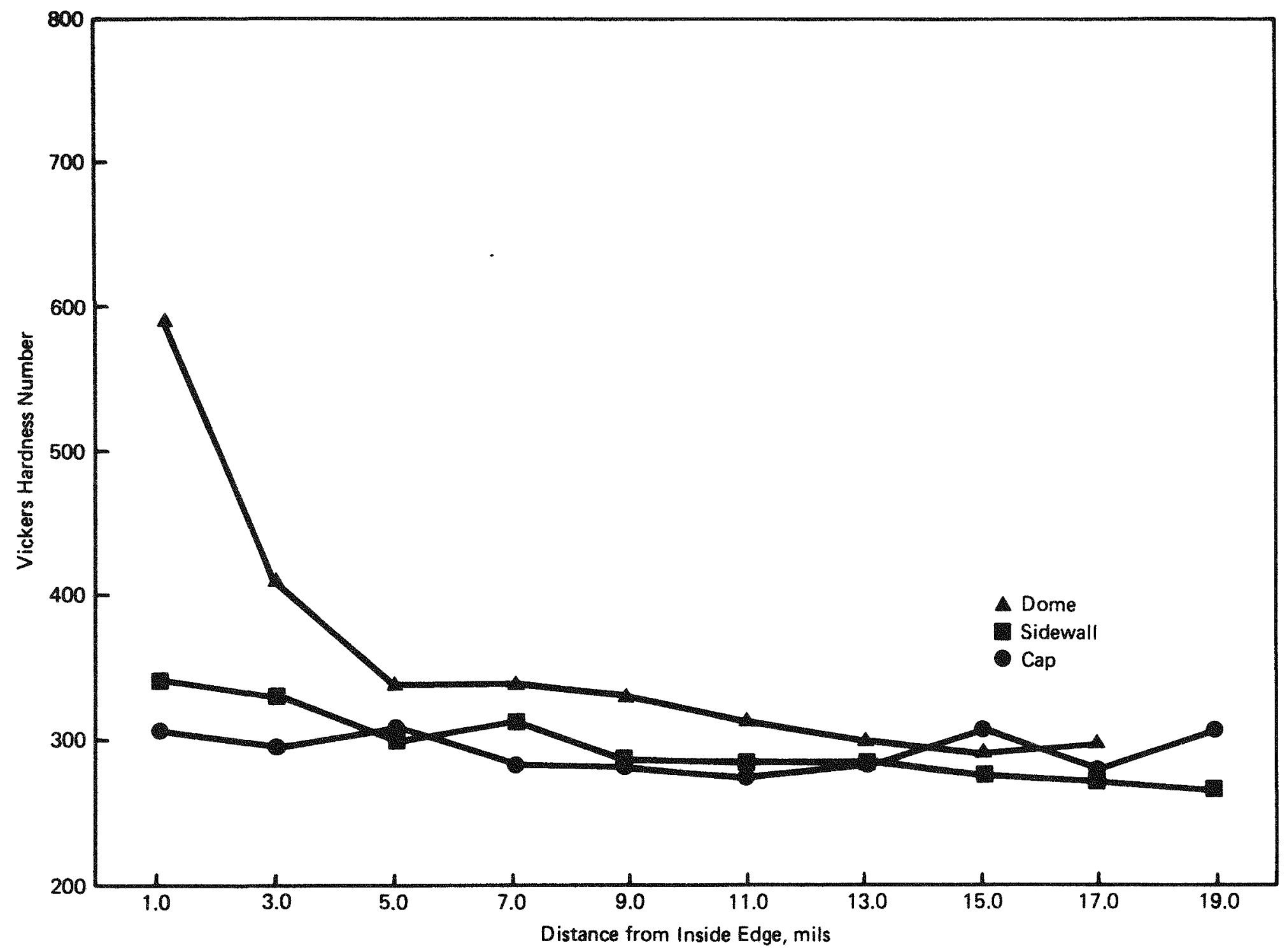




\section{Distribution}

EXTERNAL

TIC (2)

J. O. Avis, Sandia National Laboratories, Albuquérque

S. E. Bronisz, Los Alamos National Laboratory

R. H. Tait, Savannah River Laboratory

R. K. Flitcraft, Monsanto Research Corporation

H. N Hill, DOE, Dayton Area Office

G. R. Gartrell, DOE, Dayton Area Office

J. H. Grayson, DOE, Pinellas

R. A. Gregg, Savannah River Laboratory

J. H. Hines, DOE, Albuquerque Operatjons Office

R. T. Jankowski, Sandia National Labo/atories, Albuquerque (6)

T. C. Jones, DOE, Albuquerque Operations Office

E. H. Wegman, General Electric Neutron Devices, Pinellas

D. L. Plymale, DOE, Albuquerque Operations Office

R. R. Harnar, Sandia National Laboratories, Albuquerque

G. L. Bennett, DOE, ANSP, Washington

W. A. Stark, Los Alamos National Laboratory

R. Geoffrion, Los Alamos National Laboratory

Monsanto Reports Library, R2C, St. Louis

INTERNAL

W. R. Amos

C. G. Anderson

H. F. Anderson

L. R. Baird

W. G. Brothertion

A. R. Burke

T. L. Buxton

W. B. Cartmill

W. T. Cave

E. A. DeVer

D. E. Friedline

A. E. Harris

J. D. Hastings

C. W. Huntington

B. R. Kokenge

H. B. Krejder

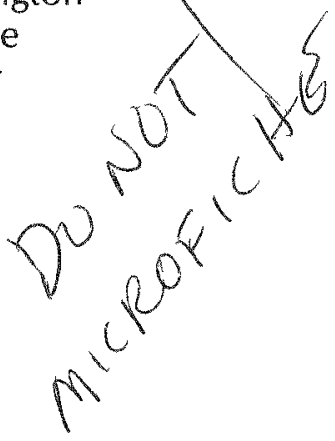

J. G. McGuffee

E. A. Mershad (2)

G. D. Miller

J. E. Newland

D. L. Prosser

W. H. Smith

P. E. Teaney (3)

R. E. Vallee

D. E. Wendeln

R. L. Wise

H. A. Woltermann

Records Center

Library (15)

Publications

Published by Information Services Stephen L. Nowka, Editor 